九州大学学術情報リポジトリ

Kyushu University Institutional Repository

Rubidium-Strontium Model of Formation of the Continental Crust and the Granite at the Island Arc

Yanagi, Takeru

Faculty of Science, Kyushu University

https://doi.org/10.5109/1544168

出版情報：九州大學理學部紀要：Series D, Geology. 22 (2)，pp.37-98，1975-02-20. Faculty of Science, Kyushu University バージョン :

権利関係 : 
Mem. Fac. Sci., Kyushu Univ., Ser. D, Geol., Vol. XXII, No. 2, pp. 37-98, text-figs. 1-31, tables 1-8, February 20, 1975

\title{
Rubidium-Strontium Model of Formation of the Continental Crust and the Granite at the Island Arc
}

\author{
Takeru YANAGI
}

\begin{abstract}
The following conclusions have been drawn through the study of a $\mathrm{Rb}-\mathrm{Sr}$ whole rock age of granites from Southwest Japan and through the comparison, in terms of $\mathrm{Rb}$ and $\mathrm{Sr}$ contents, of different kinds of unit of the earth's crust, i.e., the oceanic floor basalts (abbreviated as OFB), phanerozoic granites and recent volcanic rocks from island arcs and their corresponding orogenic belts at the continental margin.

(1) The whole rock age and the initial $\operatorname{Sr}(87 / 86)$ ratio of granites from North Kyushu are $166 \pm 40$ m.y. and $0.70414 \pm 0.00011$ for the Itoshima granodiorite, $159 \pm$ 13 m.y. and $0.70584 \pm 0.00010$ for the Haki granodiorite, and $134 \pm 26$ m.y. and $0.70456 \pm 0.00010$ for the Sawara granite respectively. The best estimate of the whole rock age of the Yatsushiro granite from Central Kyushu is $409 \pm 37$ m.y. with an initial $\operatorname{Sr}(87 / 86)$ ratio of $0.7032 \pm 0.0006$. A period of successive granitic intrusive activities in North Kyushu is about 32 m.y., as far as these whole rock age data are concerned. The difference between the $\mathrm{Rb}-\mathrm{Sr}$ whole rock age and the mean K-Ar age of granites is nearly constant, unless they underwent later thermal effect. It is about 47 m.y.

(2) The following relation between the whole rock age $t$ (m.y.) and the initial strontum isotope ratio $\mathrm{Sr}(87 / 86)$, is found among the Yatsushiro, the Funatsu, the Haki, the Amami-oshima, the Minami-osumi granitic rocks. That is $\operatorname{Sr}(87 / 86)$ 。 $=-1.15 \times 10^{-6} \mathrm{t}+0.70780 . \mathrm{A} \mathrm{Rb} / \mathrm{Sr}$ ratio calculated from the rate of growth of the $\operatorname{Sr}(87 / 86)$ ratio is about 0.278 , which is very close to the recent estimates of the abundance ratio of both elements in the continental crust.

(3) These granitic rocks, and the Sawara and the Itoshima granitic rocks are concluded to have been derived respectively from 400 and 230 m.y. old andesitic primary crusts with the $\mathrm{Rb} / \mathrm{Sr}$ ratio of about 0.27 . The initial $\mathrm{Sr}(87 / 86)$ ratio of the primary crust is estimated at 0.7033 , which is larger than the mean of OFB by 0.0006 .

(4) The major chemical composition of a material which has contaminated volcanic rocks does not vary among young orogenic belts such as island arcs and mobile belts at the continental margin, and is andesitic or somewhat more acid with the $\mathrm{Rb} / \mathrm{Sr}$ ratio close to the estimates of the abundance ratio of both elements in the continental crust.

(5) The andesites of low $\operatorname{Sr}(87 / 86)$ ratios have possibly been derived from OFB under high pressure conditions. These andesites, however, are low in $\mathrm{Rb}$ content and therefore have low $\mathrm{Rb} / \mathrm{Sr}$ ratios which are about one fifteenth of the mean $\mathrm{Rb} / \mathrm{Sr}$ ratio of the continental crust. Accordingly, it is impossible to attribute the growth of the continental crust to the accretion of these andesites. (6) It is found that the melting proportion can attain an extent of about 80 percent of OFB. And the existence of the secondary mantle current driven by
\end{abstract}

Manuscript received June 29, 1974 
the gravitational rise of a large amount of derivatives from OFB is suggested in the upper mantle beneath the island arc. This hypothetical secondary mantle current provides a favourable condition for the formation of the continental crust.

(7) Two possible alternative magmatic processes are proposed for the formation of the continental crust at the island arc. At first in both magmatic processes, OFB sink along the seismic zone into the mantle, being transformed into eclogite with the increase of depth, partially melt at depth of about $100-150 \mathrm{kms}$ and then give rise to an andesitic magma. In one of the magmatic processes, this andesitic material rises in essentially solid state or in nearly solid state with an incipient melted portion through the mantle, reaches the bottom of the continental crust, and then remelts partially and mixes with a material produced by the previous analogous magmatic process. A residuum is transported by the secondary mantle current mostly toward the inner and partly toward the outer side of the island arc. The melt fraction will meet and then be mixed with the derivative material successively ascending from the seismic zone. This magmatic process is analogous to the zone refining processing of the semiconductive material. With the proceeding of this kind of zone melting, water, primarily contained in OFB, is enriched in the liquid zone. This enrichment of water may promote the operation of this kind of the magmatic differentiation. After the operation of the zone melting for a definite period, the chemistry of the liquid zone converges into a definite composition which is equivalent to the estimated overall composition of the continental crust.

In the other alternative magmatic process, a derivative material from OFB is remelted incipiently near the base of the continental crust. And the melt fraction is squeezed out from the material and then sticked at the base of the continental crust.

The primary crust so formed has a specific $\mathrm{Rb} / \mathrm{Sr}$ ratio irrespective of its position in the island arc. $\mathrm{Rb}$ and $\mathrm{Sr}$ contents in granites can be sufficiently explained in terms of the partial melting of the primary crust.

\section{Contents}

I Introduction

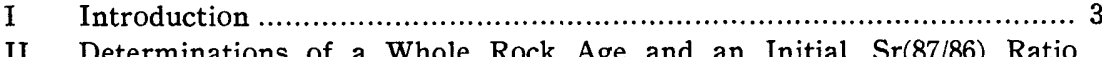
of Granites .......................................................................... 40

III The Evolution of the Initial $\mathrm{Sr}(87 / 86)$ Ratios of Granites .................... 48

IV Petrogenetic Implications of Rubidium and Strontium Contents in Volcanic Rocks ............................................................................ 53

V Principal Equations in Rubidium and Strontium Concentrations ............66 64

VI The Secondary Mantle Current beneath the Island Arc .......................6 67

VII Possible Schemes of Magmatic Process for the Formation of the Con-

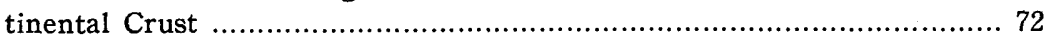

VIII The Formation of a Granite from the Primary Crust ........................ 89

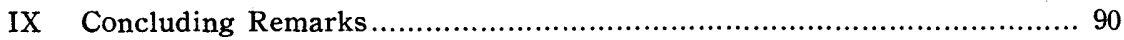

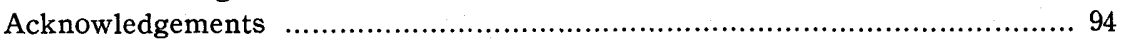

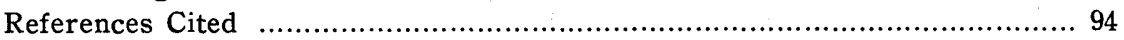

\section{Introduction}

The origin of the continental crust is a fundamental problem in geology. In 
1960's, the isotopic studies on strontium coupled with the radiometric age determination on variety of rocks from the continental shields attested important facts that there is a major addition to the continental crust of a material not enriched in radiogenic strontium 87 from the mantle and that the continent is growing in volume at accererating rates amounting to about $600 \mathrm{~km}^{3}$ per million years (Hurley et al., 1962; Hurley and Rund, 1969).

In addition to this, recent estimates of the overall chemical composition of the continental crust are close to andesite or diorite (TAYlor and White, 1965; Taylor, 1968; Ronov and Yaroshevsky, 1969; Wyllie, 1971). The andesitic model of the crust, which is differentiated into an upper granodioritic crust and a lower more basic one, is consistent with geophysical and geological observations (TAYLOR, 1968; GREen, 1970). Both of the trace element data (TAYLOR, 1968) and the high pressure experimental results (GREEN and RINGwood, 1968) have independently supported the derivation of the calc-alkaline andesite in orogenic areas from the mantle. In connection with this mantle derivation, it is noted that there exists a close relationship between the chemical composition of volcanic rocks from the island arcs and the depth of the seismic zone in the mantle (Kuno, 1966; Dickinson and Hatherton, 1967; Sugimura, 1967; Hart et al., 1970).

These facts do convince us that the continental crust grows in volume by the accretion of an andesitic material derived from the mantle. Therefore they must provide us satisfactory basis for the explanation of the origin of a granite, which occurs in every orogenic belt and occupies the most part of the continental crust.

The granite, which includes all kinds of intrusive granitoid in this paper, has an important share in the formation of the continental crust. Therefore, in connection with the origin of the continental crust, it is essential to unravel the origin of the granite. A crucial point of the granite problem is petrological prehistory of the source material of the granite,

Thus, the object of this paper is to examine petrochemical characters of the source material of the granites in terms of $\mathrm{Rb}$ and $\mathrm{Sr}$ contents, to present some additional facts for the origin of the continental crust and then to propose models of the formation of the continental crust.

In this paper, the estimation of a $\mathrm{Rb} / \mathrm{Sr}$ ratio of a source material of some granites is at first attempted through the determination of initial strontium isotope ratios and whole rock ages of these granites. Then some petrochemical characters of the lower crust are presented through the observation of the geochemical behaviours of $\mathrm{Rb}$ and $\mathrm{Sr}$ during magmatic differentiations of volcanic rocks. Then variations of $\mathrm{Rb}$ and $\mathrm{Sr}$ concentrations are calculated in the framework of certain possible differentiation schemes. Finally discussion is given about the mechanism of the formation of the continental crust and that of the granite. 


\section{Determinations of a Whole Rock Age and an Initial $\operatorname{Sr}(87 / 86)$ Ratio of Granites}

\section{(1) Geological settings of granite samples}

i) The Yatsushiro granite

In the Outer Zone of Southwest Japan, small tectonic intrusions of granite with a lenticular shape, bounded by faults, occur in the weakly metamorphosed Paleozoic sedimentary formations, accompanied with high grade metamorphic rocks along the so-called Kurosegawa Tectonic Belt extending parallel to the main trend of this region from the Kii peninsular through Shikoku to Central Kyushu. Minerals of the granites are extremely distorted, crushed and altered. These granitic rocks are considered to have been squeezed out by the late Paleozoic and Mesozoic tectonic movements (Matsumoto and Kanmera, 1946; Ichikawa et al., 1956; Minato et al., 1962).

Radiometric ages of these granitic rocks have been reported by KAWANO and Ueda (1966) with the K-Ar method, HAYASE and Ishizaka (1967), Hayase and Nohda (1969), Ishizaka (1972) and NoHda (1972) with the Rb-Sr method.

Radiometric ages of biotite of the granites and the gneisses collected from the whole areas of the Kurosegawa Tectonic Belt fall in the same range of 461 to 389 m.y. with a mean value of 428 m.y. Ages of potassium feldspar, however, are conspicuously young, giving a mean value of $288 \mathrm{~m} . \mathrm{y}$. and imply complexity of the geological history of the granites.

IsнizakA (1972) re-examined biotite ages of the granites and reported that all of these granites are contemporaneous and that an age of $399 \pm 20$ m.y. is recomended as the best estimated value. This age corresponds well with 400 m.y. of biotite of the gneiss from Yatsushiro, Central Kyushu (Noнda, 1972).

Although rock samples of the Yatsushiro granite used in this determination were collected from relatively large intrusive bodies at Hachimandaki and Uminoura in the Hinagu quadrangle of the Yatsushiro district (Matsumoto and Kanmera, 1964), minerals in all rock samples are twisted, crushed, altered and recrystallized in greater or less degree.

ii) The Itoshima, the Haki and the Sawara granitic rocks

In the Inner Zone of Southwest Japan, violent igneous activities occurred during late Mesozoic to early Tertiary. The extrusion of voluminous rhyolitic to andesitic pyroclastic rocks was followed by the successive intrusion of batholithic granites into the Paleozoic and older Mesozoic formations, setting the center of the intrusive activities in the Ryoke metamorphic belt. These batholithes of the Inner Zone are composite intrusives composed of a number of small bodies of tonalite to granite with a surface extension of 100 to $1000 \mathrm{~km}^{2}$.

In most cases, tectonic trends of older granites, outline of intrusives and 


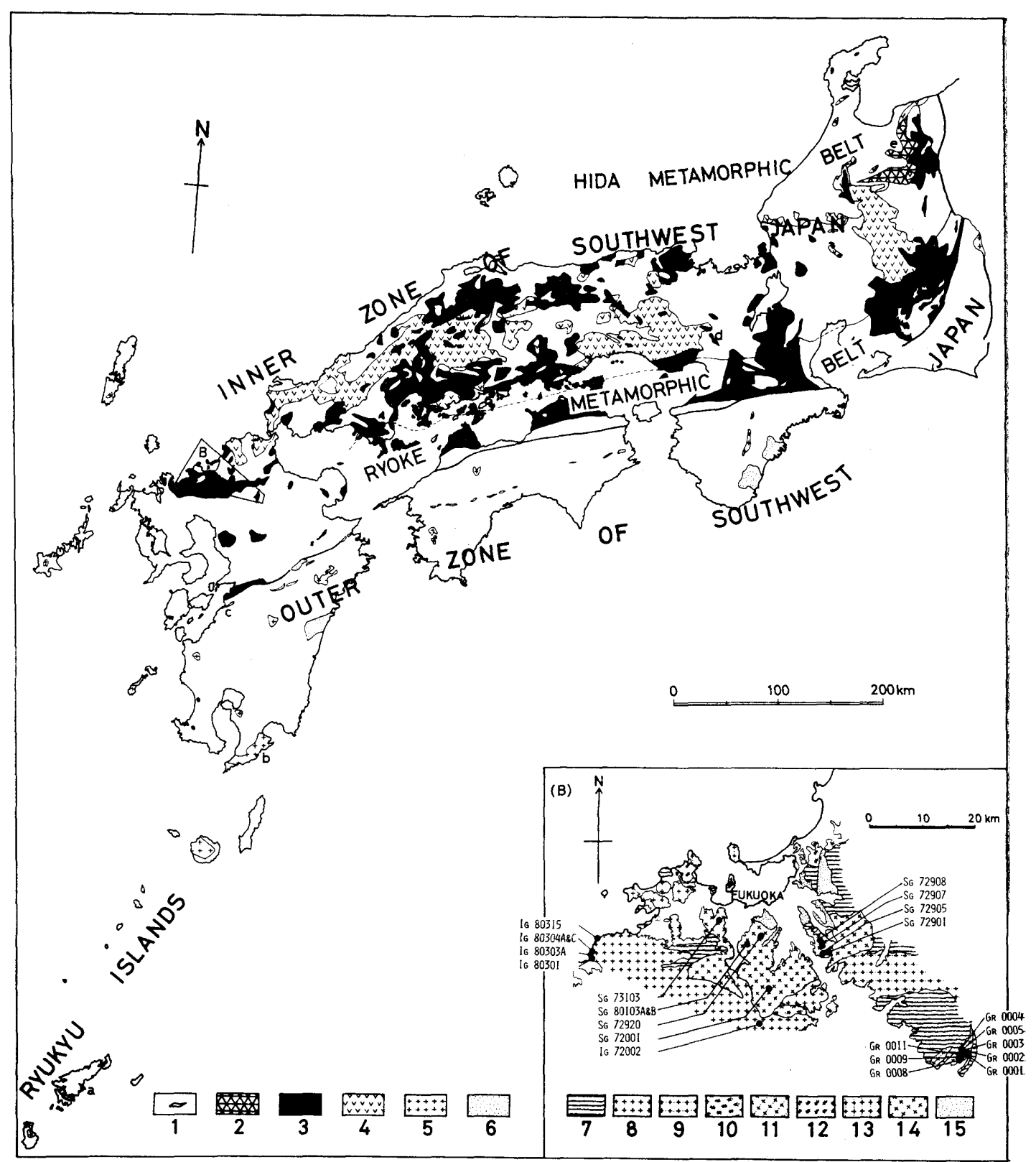

Fig. 1. Distribution of granitic and related volcanic rocks in Southwest Japan, and sample sites in North Kyushu. 1: Granitic rocks in the Kurosegawa tectonic belt, 2: Late Paleozoic or early Mesozoic granites in the Hida metamorphic belt, 3: Late Mesozoic granites, 4: Late Mesozoic volcanic rocks, 5: Cenozoic granites, 6: Middle Cenozoic acid volcanic rocks, 7: Sangun metamorphic rocks, 8: Itoshima granodiorite, 9: Asakura granodiorite, 10: Fukae granite, 11: Haki granodiorite, 12: Kitazaki granodiorite, 13: Hirao granodiorite, 14: Sawara granite, 15: Paleogene sedimentary formations. a: Amami-oshima granite, b: Minami-osumi granite, c: Yatsushiro granite, d: Ibaragi granite, e : Funatsu granite. Maps were compiled and modified from Isomi (1968) and Matsushita (1971). 
Table 1. Rb-Sr analytical data of granitic rocks

\begin{tabular}{|c|c|c|c|c|c|c|}
\hline No. & Rock & $\begin{array}{l}\mathrm{Rb} \\
\mathrm{ppm}\end{array}$ & $\begin{array}{l}\mathrm{Sr} \\
\mathrm{ppm}\end{array}$ & $\mathrm{Rb}^{87} / \mathrm{Sr}^{86}$ & $\mathrm{Sr}^{87} / \mathrm{Sr}^{86}$ & Reference \\
\hline \multicolumn{7}{|c|}{ The Yatsushiro granite } \\
\hline YG2003 & Granite & 134.2 & 114.4 & 3.40 & $0.72253 \pm 0.00020$ & (1) \\
\hline YG290IA & Granite & 93.44 & 195.9 & 1.38 & $0.70919 \pm 0.00033$ & (1) \\
\hline YG2901B & Granite & 117.6 & 62.32 & 5.48 & $0.73300 \pm 0.00026$ & (1) \\
\hline YG2902 & Granite & 75.35 & 106.0 & 2.06 & $0.71684 \pm 0.00020$ & (1) \\
\hline YG81201 & Granite & 107.7 & 104.5 & 3.20 & $0.72261 \pm 0.00020$ & (1) \\
\hline YG81202 & Granite & 97.55 & 44.23 & 6.40 & $0.72738 \pm 0.00020$ & (1) \\
\hline YG81205 & Granite & 124.6 & 59.02 & 6.13 & $0.73352 \pm 0.00020$ & (1) \\
\hline \multicolumn{7}{|c|}{ The Itoshima granodiorite } \\
\hline IG72002 & Granodiorite & 100.4 & 292.2 & 0.995 & $0.70646 \pm 0.00021$ & (1) \\
\hline IG80301 & Tonalite & 55.61 & 418.5 & 0.385 & $0.70674 \pm 0.00023$ & (1) \\
\hline IG $80303 \mathrm{~A}$ & Granite & 115.1 & 326.0 & 1.022 & $0.70647 \pm 0.00020$ & (1) \\
\hline$I G 80304 \mathrm{~A}$ & Diorite & 83.10 & 304.3 & 0.790 & $0.70605 \pm 0.00043$ & (1) \\
\hline IG80304C & Adamelifte & 73.6 & 443.4 & 0.481 & $0.70519 \pm 0.00033$ & (1) \\
\hline IG80315 & Pegmatite & 155.8 & 138.2 & 3.26 & $0.70855 \pm 0.00027$ & (1) \\
\hline \multicolumn{7}{|c|}{ The Sawara granite } \\
\hline$S G 72001$ & Granite & 83.56 & 361.7 & 0.669 & $0.70580 \pm 0.00022$ & (1) \\
\hline SG72905 & Granite & 113.2 & 284.3 & 1.153 & $0.70679 \pm 0.00022$ & (1) \\
\hline SG72907 & Granite & 115.8 & 307.8 & 1.089 & $0.70659 \pm 0.00021$ & (1) \\
\hline SG72908 & Granite & 83.87 & 410.2 & 0.592 & $0.70561 \pm 0.00052$ & (1) \\
\hline SG72920 & Granite & 91.34 & 400.0 & 0.661 & $0.70587 \pm 0.00031$ & (1) \\
\hline SG73103 & Granite & 99.18 & 331.5 & 0.866 & $0.70602 \pm 0.00022$ & (1) \\
\hline$S G 80103 \mathrm{~A}$ & Granite & 94.5 & 433.8 & 0.631 & $0.70582 \pm 0.00020$ & (1) \\
\hline SG80103B & Diorite & 22.43 & 1141 & 0.0569 & $0.70467 \pm 0.00036$ & (1) \\
\hline SG72901 & Pegmatite & 215.0 & 21.94 & 28.5 & $0.74350 \pm 0.00052$ & (1) \\
\hline \multicolumn{7}{|c|}{ The Haki granodiorite } \\
\hline Gro001 & Granodiorite & 86.58 & 284.8 & 0.880 & $0.70782 \pm 0.00020$ & (1) \\
\hline Gr0002 & Granodiorite & 83.16 & 268.7 & 0.896 & $0.70786 \pm 0.00021$ & (1) \\
\hline Gro003 & Granodiorite & 79.03 & 280.4 & 0.816 & $0.70751 \pm 0.00035$ & (1) \\
\hline Gr0004 & Granodiorite & 88.95 & 261.4 & 0.985 & $0.70803 \pm 0.00020$ & (1) \\
\hline Gr0005 & Granodiorite & 89.60 & 247.8 & 1.047 & $0.70817 \pm 0.00050$ & (1) \\
\hline Gro008 & Granodiorite & 89.21 & 269.7 & 0.958 & $0.70797 \pm 0.00020$ & (1) \\
\hline Gro009 & Diorite & 21.08 & 446.2 & 0.1368 & $0.70615 \pm 0.00024$ & (1) \\
\hline Gro011 & Granite & 63.81 & 146.4 & 1.262 & $0.70864 \pm 0.00020$ & (1) \\
\hline Gro012 & Granite & 118.79 & 146.2 & 2.35 & $0.71106 \pm 0.00020$ & (1) \\
\hline \multicolumn{7}{|c|}{ The Minami-osumi granite } \\
\hline TN62030801 & Granodiorite & 156.2 & 184.6 & 2.450 & $0.70923 \pm 0.00038$ & (2) \\
\hline TN62022308 & Adamellite & 167.5 & 185.0 & 2.629 & $0.70947 \pm 0.00038$ & (2) \\
\hline TN62022308B & Granite & 183.9 & 95.5 & 5.580 & $0.71207 \pm 0.00038$ & (2) \\
\hline TN64030405 & Granodiorite & 189.9 & 134.2 & 4.099 & $0.71087 \pm 0.00042$ & (2) \\
\hline TN620307IIA & Granodiorite & 179.3 & 161.7 & 3.211 & $0.71217 \pm 0.00038$ & (2) \\
\hline \multicolumn{7}{|c|}{ The granite from Amami-oshima } \\
\hline TN65021310A & Tonalite & 136.9 & 147.1 & 2.695 & $0.71034 \pm 0.00038$ & (2) \\
\hline TN65021310B & Tonalite & 129.3 & 124.8 & 3.002 & $0.71087 \pm 0.00044$ & (2) \\
\hline TN65021310C & Quartz diorite & 143.5 & 121.2 & 3.417 & $0.71147 \pm 0.00038$ & (2) \\
\hline $\operatorname{TN} 65021402$ & Granodiorite & 115.0 & 134.8 & 2.471 & $0.71124 \pm 0.00038$ & (2) \\
\hline TN65020401 & Granodiorite & 124.7 & 140.1 & 2.575 & $0.71008 \pm 0.00053$ & (2) \\
\hline TN65021404 & Tonalite & 104.1 & 145.2 & 2.077 & $0.70956 \pm 0.00038$ & (2) \\
\hline
\end{tabular}


Table 1. Continued

\begin{tabular}{|c|c|c|c|c|c|c|}
\hline No. & Rock & $\begin{array}{l}\mathrm{Rb} \\
\mathrm{ppm}\end{array}$ & $\begin{array}{l}\mathrm{Sr} \\
\mathrm{ppm}\end{array}$ & $\mathrm{Rb}^{87} / \mathrm{Sr}^{86}$ & $\mathrm{sr}^{87} / \mathrm{sr}^{86}$ & Reference \\
\hline The & Ibaragi granitic & complex & & & & \\
\hline $\mathrm{KI}-\mathrm{I}$ & Quartz diorite & $77 \cdot 38$ & 370.3 & 0.605 & 0.7068 & (3) \\
\hline$K I-5$ & Adamelite & 288.0 & 178.7 & 4.663 & 0.7122 & (3) \\
\hline KI- 6 & Granodiorite & 201.9 & 244.8 & 2.601 & 0.7096 & (3) \\
\hline $\mathrm{KI}-7$ & Granodiorite & 212.7 & 176.6 & 3.487 & 0.7104 & (3) \\
\hline The & Funatsu granitic & rocks & & & & \\
\hline HD67053003 & Adameliite & 85.4 & 194 & 1.276 & 0.7092 & (4) \\
\hline HD67053102 & Tonalite & 75.8 & 192 & 1.142 & 0.7083 & (4) \\
\hline HD67053103 & Diorite & 68.1 & 308 & 0.6398 & 0.7070 & (4) \\
\hline HD67053104 & Tonalite & 37.5 & 613 & 0.1772 & 0.7062 & (4) \\
\hline
\end{tabular}

1: This paper, 2 : Yanagi, Yamaguchi and NozaWa $(1971), 3:$ Ishizaka $(1971) 4$ : Shibata, WaNLESS and NozaWa (1970)

foliation, are concordant with the general structural trend of the Paleozoic formations, whereas younger intrusives cut these general trends of the Paleozoic formations and older granitic intrusives.

$\mathrm{K}-\mathrm{Ar}$ age data of these granites have a bimodal character with two peaks of 95 and 70 m.y. in Central Honshu, 80 and 60 m.y. in the Kinki district, and 85 and 55 m.y. in the Chuogoku district (NozAwA, 1970). In Kyushu, mineral ages cluster around 95 m.y. (ditto).

Granites in North Kyushu, belonging to the same series of the late Mesozoic acid igneous activities, have been classified into more than eleven small intrusive bodies (KARAKida et al., 1965; Matsushita, 1971). The earliest one of these successive intrusive granites is the Itoshima granodiorite, a heterogeneous coarse grained plutonic rock with the foliation of biotite and hornblende, including a large number of spheroidal and ellipisoidal dark inclusions and intruded into the Sangun metamorphic rocks derived from Paleozoic sedimentary formations. The latest one of these granites is the Sawara granite, a massive medium grained porphyritic granite with phenocrysts of potassium feldspar and intruded discordantly into the Itoshima granodiorite and the Sangun metamorphic rocks.

The Haki granodiorite, isolated in the Sangun metamorphic rocks, is a massive medium grained plutonic rock with a small number of dark inclusions. Rock samples were collected from these three granitic rocks (Fig. 1, B)

iii) The Amami-oshima and the Minami-osumi granites

In the Outer Zone of Southwest Japan and the Ryukyu Islands, folded sedimentary rocks of Mesozoic to middle Cenozoic ages were intruded by many small stocks and dykes of granite. The feature of these intrusive activities accompanying the extrusion of acid pyrocrastic rocks in southern Kyushu and the Kii peninsular are similar to those of the Mesozoic acid igneous activities, although the exposed areas are narrower than the latter. One of these granite bodies, 
Table 2. Ages and initial $\operatorname{Sr}(87 / 86)$ ratios of granites

\begin{tabular}{lcl}
\hline \multicolumn{1}{c}{ Rock } & Age (m.y.) & Inftial $\mathrm{sr}^{87} / \mathrm{sr}^{86}$ \\
\hline Yatsushiro granite & $409 \pm 37$ & $0.7032 \pm 0.0006$ \\
Itoshima granodiorite & $166 \pm 40$ & $0.70414 \pm 0.00011$ \\
Hak1 granodiorite & $159 \pm 13$ & $0.70584 \pm 0.00010$ \\
Sawara granite & $134 \pm 26$ & $0.70456 \pm 0.00010$ \\
Amami-oshima granite & $105 \pm 27$ & $0.7065 \pm 0.0002$ \\
Minami-osumi granite & $63 \pm 11$ & $0.7071 \pm 0.0002$ \\
Ibaragi granitic complex & $97 \pm 14$ & $0.7059 \pm 0.0003$ \\
Funatsu granitic rocks & $175 \pm 53$ & $0.7056 \pm 0.0007$ \\
\hline
\end{tabular}

the Minami-osumi granite, is large enough to be called batholith with a surface extension of about $750 \mathrm{~km}^{2}$.

Ages of intrusion of these stocks and the relation between the intrusion and the tectonic movement have been discussed by YANAGI et al. (1971). Mineral ages of the stocks and dykes are old in the Ryukyu Islands, 21 to 61 m.y. and young in the Outer Zone of Southwest Japan, 11 to 21 m.y. (NozAwA, 1968). Rock samples were collected from the Amami-oshima in the Ryukyu Islands and the Minami-osumi in southern Kyushu.

\section{(2) Analytical procedures}

An amount of $100-500 \mathrm{mg}$ of a sample from a rock powder of $800-3000 \mathrm{~g}$ is used for the analyses of concentrations of $\mathrm{Rb}$ and $\mathrm{Sr}$, and of strontium isotope ratios. Concentrations of $\mathrm{Rb}$ and $\mathrm{Sr}$ are determined by the isotope dilution method with two mass spectrometers. Strontium isotope ratios are measured on an unspiked sample containing about $4-8 \mu \mathrm{g}$ of $\mathrm{Sr}$. The mass spectrometers used were HITACHI RMU-5G with an analyser tube radius of $20 \mathrm{~cm}$ and JEOL JMS05RB with the tube radius of $30 \mathrm{~cm}$. The output of the solid state vibrating reed electrometer of TAKEDA TR84JIS or of the solid state directly connected DC ampliphire of HITACHI is integrated for 2 seconds with a digital voltmeter of TAKEDA TR6516A equipped with V-F converter, and then printed out automatically.

$\operatorname{Sr}(87 / 86)$ ratios listed in Table 1 are a mean value of 200 to 500 peak sets and normalized to 0.1194 of $\operatorname{Sr}(86 / 88)$ ratio. Detailed techniques for the determination of concentrations of $\mathrm{Rb}$ and $\mathrm{Sr}$ and strontium isotope ratios have been reported by Yamaguchi et al. (1969), Yanagi et al. (1970) and Yanagi et al. (1971). The concentrations of $\mathrm{Rb}$ and $\mathrm{Sr}$, and the $\mathrm{Sr}(87 / 86)$ ratios are listed in Table 1 with other data reported by Shibata et al. (1970), Ishizaka (1971) and Yanagi et al. (1971).

An error of $\operatorname{Sr}(87 / 86)$ ratios is indicated with a twice of the standard deviation. The mean of the errors is 0.00020 . Errors below 0.00020 are magnified to this level, and errors over 0.00020 are shown in Table 1 . Relative errors for $\mathrm{Rb}$ and 
Table 3. $\mathrm{Rb}-\mathrm{Sr}$ analytical data of biotites from the Sawara granite

\begin{tabular}{llllcl}
\hline No. & Mineral & $\begin{array}{l}\mathrm{Rb} \\
\mathrm{ppm}\end{array}$ & $\begin{array}{l}\mathrm{Sr} \\
\mathrm{ppm}\end{array}$ & $\mathrm{Rb}^{87} / \mathrm{Sr}^{86}$ & $\mathrm{Sr}^{87} / \mathrm{Sr}^{86}$ \\
\hline SG72001 & Biotite & 620 & 8.15 & 228.0 & $1.06499 \pm 0.00044$ \\
SG72907 & Biotite & 733 & 6.50 & 344.8 & $1.27380 \pm 0.00075$ \\
SG72920 & Biotite & 659 & 7.00 & 283.4 & $1.1190 \pm 0.0013$ \\
SG73103 & Biot1te & 766 & 6.11 & 384.6 & $1.30857 \pm 0.00055$ \\
\hline
\end{tabular}

Sr concentrations were estimated to be less than 3 percent for $\mathrm{Rb}$ and 1 percent for Sr. A decay constant of rubidium 87 used in this paper is $1.39 \times 10^{-11} /$ year. All $\mathrm{Rb}-\mathrm{Sr}$ age data cited in this paper are recalculated with this decay constant.

\section{(3) Analytical results}

i) Whole rock ages and initial $\mathrm{Sr}(87 / 86)$ ratios of granites

Whole rock ages and initial $\mathrm{Sr}(87 / 86)$ ratios of granites are shown in Figs. 2 and 3, and Table 2. The whole rock age of the Haki granodiorite is $159 \pm 13$ m.y. with an initial $\operatorname{Sr}(87 / 86)$ ratio of $0.70584 \pm 0.00010$. The whole rock age of the Itoshima granodiorite is $166 \pm 40$ m.y., while the whole rock age of the Sawara granite is $134 \pm 26$ m.y. The Sawara granite is about 32 m.y. younger than the Itoshima granodiorite. The age of the Itoshima granodiorite is very close to that of the Haki granodiorite. Initial $\operatorname{Sr}(87 / 86)$ ratios are $0.70414 \pm 0.00011$ for the Itoshima granodiorite and $0.70456 \pm 0.00010$ for the Sawara granite.

A whole rock age of a pegmatite in the Sawara granite is 97 m.y. That of

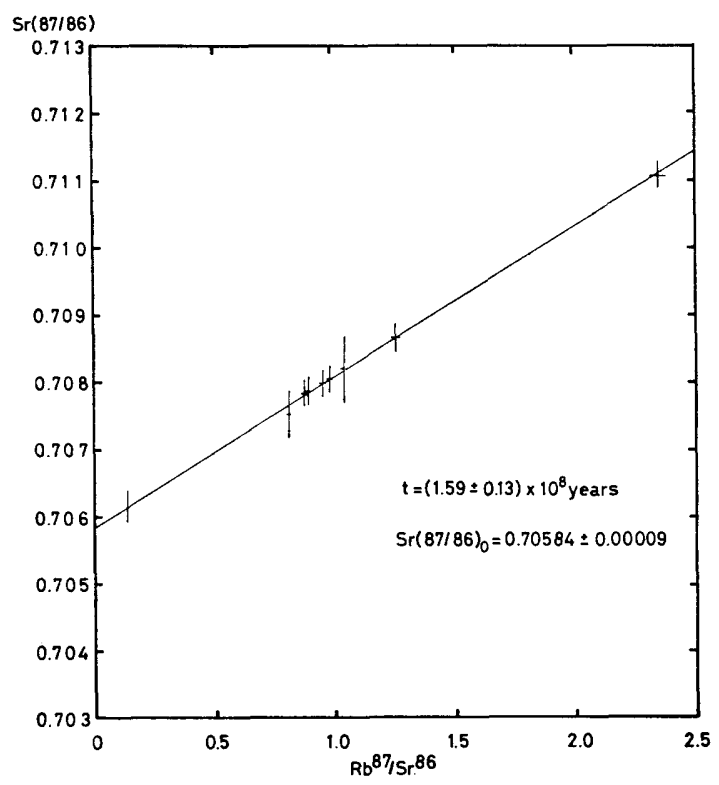

Fig. 2. The isochron of the Haki granodiorite in North Kyushu. The whole rock age is $159 \pm 13 \mathrm{~m} . \mathrm{y}$. and the initial $\operatorname{Sr}(87 / 86)$ ratio is $0.70584 \pm 0.00010$. 
Table 4. $\mathrm{Rb}-\mathrm{Sr}$ biotite ages of the Sawara granite

\begin{tabular}{clcc}
\hline No. & Mineral & $\begin{array}{c}\text { Age } \\
(\mathrm{m} . \mathrm{y} .)\end{array}$ & Inttial $\mathrm{Sr}^{87} / \mathrm{Sr}^{86}$ \\
\hline SG72001 & Blot1te & $114 \pm 4$ & 0.70474 \\
SG72907 & Biotite & $119 \pm 4$ & 0.70479 \\
SG72920 & Blotite & $105 \pm 4$ & 0.70490 \\
SG73103 & Biot1te & $113 \pm 4$ & 0.70466 \\
\hline
\end{tabular}

a pegmatite in the Itoshima granodiorite is about '/4 m.y., but this latter pegmatite age is errorneous, because a strontium isotope ratio of the pegmatite is very close to the mean strontium isotope ratio of the Itoshima granodiorite.

ii) Relations among radiometric ages determined with different methods

Ages determined with different methods on the Sawara granite display an interesting aspect (Table 5), The Sawara granite is the youngest of the late Mesozoic successive intrusions in North Kyushu, where there is no thermal affection caused by later igneous activities. Therefore the relation found among these ages may originate in a simple cooling process. This condition is the same as that of the Amami-oshima and the Minami-osumi granites. Firstly it is noticed from the observation of Table 5 that the difference between the whole rock age and the mean $\mathrm{K}-\mathrm{Ar}$ biotite age is very similar for these cases, as has already been noticed by Yanagi et al. (1971). The differnce is 46 m.y. for the Sawara granite, 52 m.y. for the Amami-oshima granite and 45 m.y. for the Minami-osumi

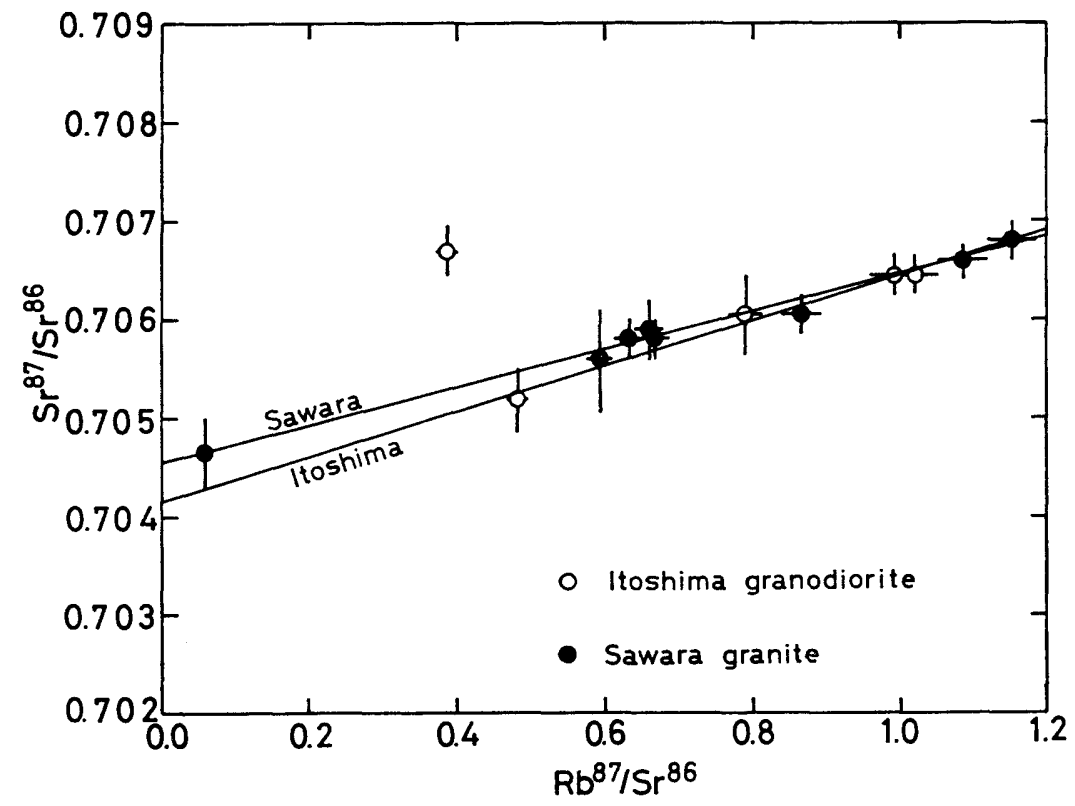

Fig. 3. Isochrons of the Itoshima granodiorite and the Sawara granite in North Kyushu. The whole rock age of the Itoshima granodiorite is $166 \pm 40 \mathrm{~m} . \mathrm{y}$. with the initial $\operatorname{Sr}(87 / 86)$ ratio of $0.70414 \pm 0.00011$. The whole rock age of the Sawara granite is $134 \pm$ 26 m.y. with the initial $\operatorname{Sr}(87 / 86)$ ratio of $0.70456 \pm 0.00010$. 
Table 5. Comparison of ages determined with different methods

\begin{tabular}{|c|c|c|c|c|}
\hline & $\begin{array}{c}\text { Whole rock age } \\
(\mathrm{m} . \mathrm{y} \cdot)\end{array}$ & $\begin{array}{l}\mathrm{Rb}-\mathrm{Sr} \text { blotite } \\
\text { age }(\mathrm{m} \cdot \mathrm{y} \cdot)^{*}\end{array}$ & $\begin{array}{l}\text { K-Ar biotite } \\
\text { age (m.y.)* }\end{array}$ & $\begin{array}{c}\text { Pegmat1te age } \\
(\mathrm{m} \cdot \mathrm{y} \cdot)^{-}\end{array}$ \\
\hline Itoshima granodiorite & 166 & & $92(3) * *$ & 74 \\
\hline Hak1 granodiorite & 159 & $116(4) * *$ & & \\
\hline Sawara granite & 134 & $113(4)$ & $88(6) * *$ & 97 \\
\hline Amami-oshima granite & 105 & & $54(4) * *$ & \\
\hline Minami-osumi granite & 64 & & $19(3)^{* *}$ & \\
\hline
\end{tabular}

* Mean values, ** Data are taken from Shibata and Karakida (1965), Miller et al. (1962), KaWano and Ueda (1966), Shibata and Nozawa (1966) and Yanagi (1971).

Figure in parentheses is the number of samples.

granite. These time expansions are significantly longer than a life of a magma, 1 to 10 m.y. (Shimazu, 1961). If the whole rock age is assumed to be the differentiation time for the granite, then the $\mathrm{K}$-Ar age should be regarded to represent much later stage of the cooling history of the magma. It may be a time of the upheaval and the erosion of the land. This may be also infered from the whole rock age of the pegmatite in the Sawara granite, which is 97 m.y., older than the mean $\mathrm{K}-\mathrm{Ar}$ age by about $11 \mathrm{~m} . \mathrm{y}$. This pegmatite is a thin veinlet cutting sharply the Sawara granite. In connection with this interpretation of the $\mathrm{K}$-Ar age, Matsumoto (1968) has found the following interesting relation between the history of the emplacement of Cretaceous granitic rocks and the sedimentary history in Japan. In his words, the time of the marine sedimentation is in the interval between two major peaks of granite $\mathrm{K}-\mathrm{Ar}$ age data. The epoch of granite emplacement is the time of regression in the sedimentary basin or that of land emergence.

There is the mean $\mathrm{Rb}-\mathrm{Sr}$ biotite age of the Sawara granite midway between the whole rock age and the pegmatite age. And the $\mathrm{Rb}-\mathrm{Sr}$ biotite age is concordant to that of the Haki granodiorite. The Haki granodiorite is isolated in the Sangun metamorphic rocks and much apart from the Sawara granite. Accordingly the coincidence of its $\mathrm{Rb}-\mathrm{Sr}$ biotite age with that of the Sawara granite does not imply the thermal affection caused by the intrusion of the Sawara granite. Therefore the coincidence of the $\mathrm{Rb}-\mathrm{Sr}$ or $\mathrm{K}-\mathrm{Ar}$ biotite ages of older and younger granites should be interpreted in connection with the tectonic history.

iii) The best estimate of the whole rock age and the initial $\operatorname{Sr}(87 / 86)$ ratio of the Yatsushiro granite

Whole rock data of the Yatsushiro granite are scattered over the errors of analysis as shown in Fig. 4. This is probably attributed to the alteration to which the granite was subjected after the solidification. Therefore an isochron should not be drawn through these data with the equal confidence level. The coincidence of the biotite ages of the granitic rocks from the Kurosegawa Tectonic Belt indicates that the biotite could preserve its $\mathrm{Rb}$ and $\mathrm{Sr}$ contents during the 
alteration of the granite.

All of age data of potassium feldspar of the granites from the Kurosegawa Tectonic Belt indicate that the potassium feldspar has lost more radiogenic strontium 87 relatively to $\mathrm{Rb}$ during the alteration. Young ages of potassium feldspar and the scattering of the whole rock data indicate that a portion of the radiogenic strontium 87 lost from the potassium feldspar has been transported out from the rock system without being captured by other minerals in the rock. In general, a rate of loss of an element by diffusion from minerals depends on a grain size. Therefore, in this case, it is possible to assume that an amount of lost radiogenic strontium 87 from the rock system depends on the grain size of the potassium feldspar. This relation is observed in the data of the Yatsushiro granite. The grain size of the potassium feldspar of the granites plotted on the upper left hand side in Fig. 4 is larger than that of the rocks plotted on the lower right hand side. Therefore an isochron was drawn through the data of the rocks having coarse grained potassium feldspar. This isochron gives an age of $409 \pm 37$ m.y. with an initial $\operatorname{Sr}(87 / 86)$ ratio of $0.7032 \pm 0.0006$. This age is very close to the best estimate of 399 m.y. of biotite of the granites from the Kurosegawa Tectonic Belt.

\section{The Evolution of the Initial $\operatorname{Sr}(87 / 86)$ Ratios of the Granites}

\section{(1) The relation between the whole rock ages and the initial $\operatorname{Sr}(87 / 86)$} ratios

Whole rock ages and initial $\operatorname{Sr}(87 / 86)$ ratios in Table 2 are plotted on the

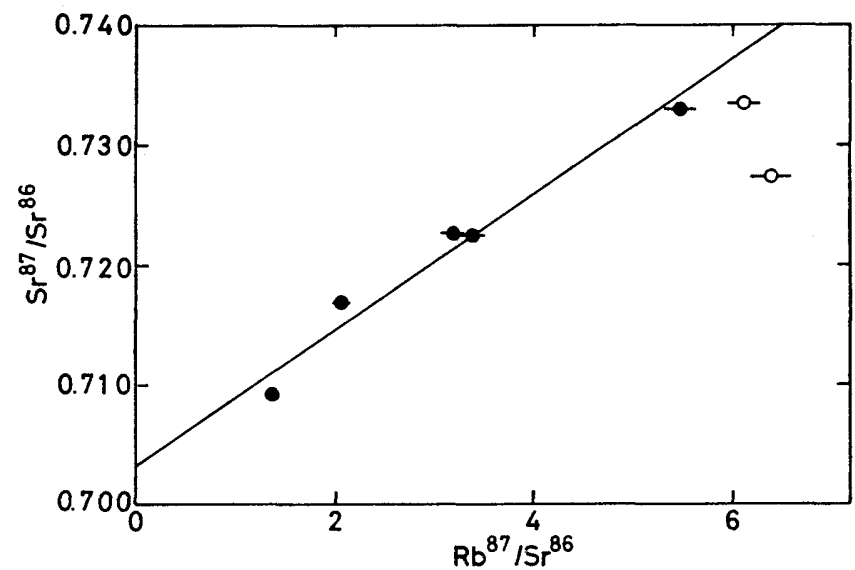

Fig. 4. The isochron of the Yatsushiro granite in Central Kyushu. Solid circles represent coarse grained granite samples, while open circles represent rather fine grained ones. The isochron is drawn through the data of rocks having coarse grained potassium feldspar. The age is $409 \pm 37$ m.y. with the initial $\mathrm{Sr}(87 / 86)$ ratio of $0.7032 \pm 0.0006$. 
$\operatorname{Sr}(87 / 86)$ vs. whole rock age diagram (Fig. 5). In the same Fig. 5, a line is also drawn from the mean $\mathrm{Sr}(87 / 86)$ ratio of OFB with the slope corresponding to the mean $\mathrm{Rb} / \mathrm{Sr}$ ratio of OFB. This is shown as a reference of the upper mantle material. The two lines drawn on either sides of this line indicate the standard deviation of the $\mathrm{Sr}(87 / 86)$ ratios of $\mathrm{OFB}$. The $\mathrm{Rb} / \mathrm{Sr}$ ratio of the upper mantle material may be somewhat smaller than that of OFB, but the difference between them is not significant for the following discussions.

All of the initial $\mathrm{Sr}(87 / 86)$ ratios of the granites scattered over the reference line indicate the derivation of these granites from sialic crustal materials. Among the plotted data, points of the Minami-osumi, the Amami-oshima, the Haki and the Funatsu granitic rocks are disposed in a line as shown in Fig. 5 and the point of the Yatsushiro granite is on the extension of the same line. Other data are scattered in the intermediate area between this apparent growth line of the initial $\operatorname{Sr}(87 / 86)$ ratios and the reference line. The slope of the apparent growth line corresponds to the $\mathrm{Rb} / \mathrm{Sr}$ ratio of 0.278 . This $\mathrm{Rb} / \mathrm{Sr}$ ratio is very close to the mean crustal abundance ratio of $\mathrm{Rb}$ to $\mathrm{Sr}$. The mean abundances of both elements and the $\mathrm{Rb} / \mathrm{Sr}$ ratio in the continental crust are listed in Table 6 . Therefore it is possible to assume that this apparent growth line may represent

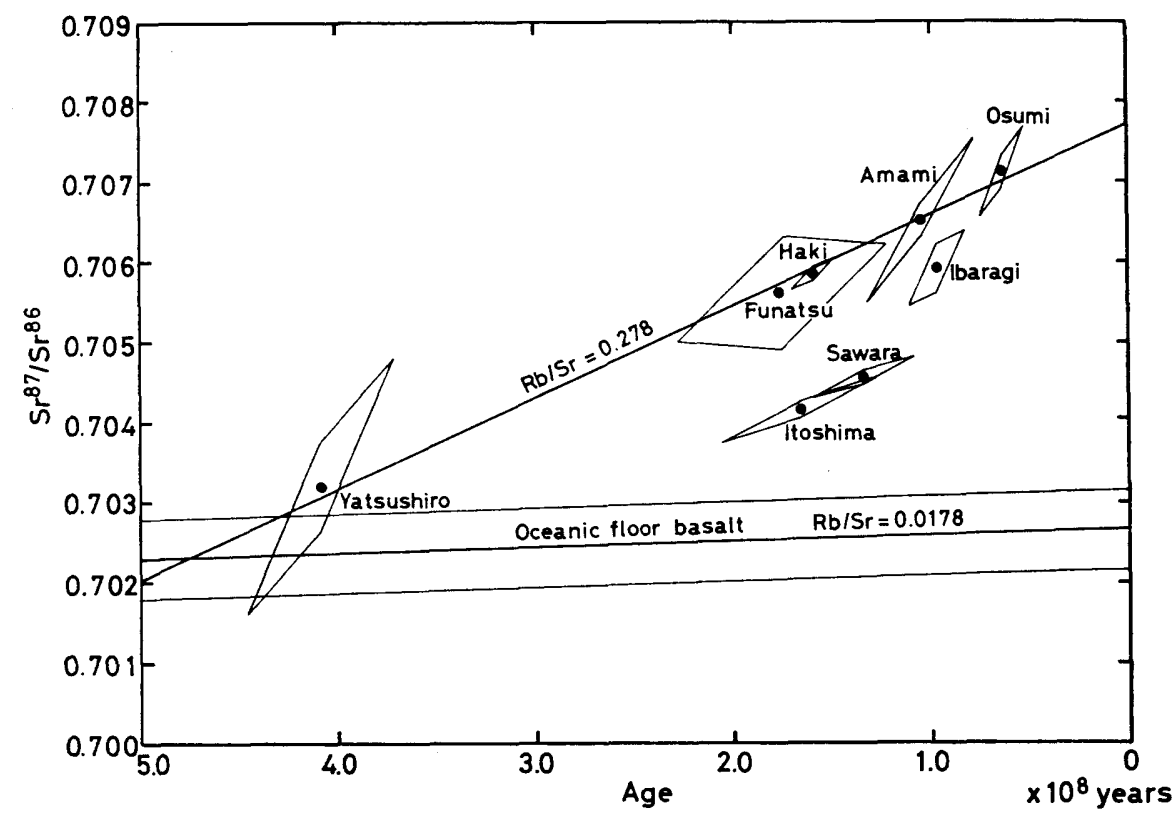

Fig. 5. The relation between whole rock ages and initial $\mathrm{Sr}(87 / 86)$ ratios of granites from Southwest Japan. The mean $\operatorname{Sr}(87 / 86)$ ratio of OFB is shown with the standard deviation as a reference of the upper mantle material. The apparent growth line of the initial $\mathrm{Sr}(87 / 86)$ ratio is drawn through the data of the Yatsushiro, the Funatsu, the Haki, the Amami-oshima and the Minami-osumi granitic rocks. The $\mathrm{Rb} / \mathrm{Sr}$ ratio calculated from the slope of the line is 0.278 . 
the growth of the $\mathrm{Sr}(87 / 86)$ ratio in a source material of these granitic rocks. In other words, these granitic rocks may be originated from the common source material.

The linear arrangement of data points, however, is a necessary but not sufficient condition for the recognition of derivation of these granitic rocks from the common source material. The sufficient condition for the granites to make a common radiogenic strontium growth line is that a $\mathrm{Rb} / \mathrm{Sr}$ ratio, an initial $\mathrm{Sr}(87 / 86)$ ratio and an age of formation should be respectively identical among the source materials of these granitic rocks. In this case, however, there is no available evidence to indicate that any of these three is positively fulfilled by a suite of granitic rocks disposed in the line in Fig. 5. Consequently this time dependent variation of the initial $\operatorname{Sr}(87 / 86)$ ratios should be called an apparent growth line.

\section{(2) The relation between the apparent growth of the initial $\operatorname{Sr}(87 / 86)$ ratio and the andesitic model of the crust}

Recently proposed crustal models indicate that the earth's continental crust has an overall composition approximating to diorite or andesite (TAYLOR and WHITE, 1965; Taylor, 1968; Ronov and Yaroshevsky, 1969; Wyllie, 1971). Taylor (1969) reported that trace element data of andesites are consistent with the derivation of the calc-alkaline andesite from the mantle in orogenic areas. Independently of this report, high pressure experimental results of GREen and Ringwood (1968) supported the derivation of the calc-alkaline rock suite from the mantle. TAYLor (1968) reported also that an andesitic model of the crust is consistent with density and heat flow data, seismic evidence and geological evidence. Experiments of GREEN (1970) supported the model of the differentiated lower crust composed of diorite or gabbroic anorthite.

If the andesitic model of the crust is admitted, a granite may have its origin in the andesitic crust. If a certain suite of granitic rocks of different ages has originated from the partial melting of the andesitic crust, the initial $\mathrm{Sr}(87 / 86)$ ratios of this suite of granites give a rate of the growth of the $\mathrm{Sr}(87 / 86)$ ratio in the andesitic crust. The slope of the growth of the $\operatorname{Sr}(87 / 86)$ ratio should give an equivalent $\mathrm{Rb} / \mathrm{Sr}$ ratio to the mean abundance ratio of $\mathrm{Rb}$ to $\mathrm{Sr}$ in the crust. An age when the $\operatorname{Sr}(87 / 86)$ ratio of the andesitic crust becomes equivalent to that of the mantle is the time of formation of the andesitic crust. Therefore the coincidence of the $\mathrm{Rb} / \mathrm{Sr}$ ratio calculated from the slope of the apparent growth line with the mean $\mathrm{Rb} / \mathrm{Sr}$ ratio of the crust is consistent with the andesitic model of the crust.

An age of 480 m.y., which is given by the intersection of the apparent growth line with the growth line for $\mathrm{OFB}$, is a time of formation of the andesitic crust. The data of the Itoshima and the Sawara granitic rocks give another age of 300 
Table 6. Sialic crustal abundances of rubidium and strontium

\begin{tabular}{ccccc}
\hline No. & $\begin{array}{c}\text { Rubidium } \\
(\mathrm{ppm})\end{array}$ & $\begin{array}{c}\text { Strontium } \\
(\mathrm{ppm})\end{array}$ & Rubidium/Strontium & Reference \\
\hline 1 & 74 & $450^{*}$ & 0.16 & $(1)$ \\
2 & 115 & $450^{*}$ & 0.26 & $(2)$ \\
3 & 117 & 434 & 0.27 & $(3)$ \\
4 & & & 0.25 & $(3)$ \\
5 & 90 & 357 & 0.24 & $(4)$ \\
\hline
\end{tabular}

(1): GaSt (1960), (2): Ahrens and T $\mathrm{T}_{\text {AYLOR }}$ (1961), (3): Hurlegy et al (1962), (4): TaYLOR (1965), * : TUREKian and KulP (1956)

m.y. as the time of formation of their source andesitic crust. These ages may imply the episodic growth of the crust with the addition of the andesitic material from the mantle.

\section{(3) The discrimination of two types among the granitic rocks}

In connection with the apparent growth of the initial $\operatorname{Sr}(87 / 86)$ ratios of the granites, the important fact is that a suite of granitic rocks lying on the apparent growth line is separated from others by a line $\mathrm{AB}$ on the $\log \mathrm{Sr}$ vs. $\log \mathrm{Rb}$ diagram as shown in Fig. 6. $\mathrm{Rb}$ and $\mathrm{Sr}$ contents in the Minami-osumi, the Amami-oshima, the Haki, the Funatsu and the Yatsushiro granitic rocks are scattered on the lower left hand side of the line $A B$ in Fig. 6, while both contents in other granitic rocks are protted on the upper right hand side.

As the general trend of variation of both concentrations, $\mathrm{Rb}$ content increases and the Sr content decreases in a residual magma with the proceeding of the magmatic differentiation at low pressures. From the observation of the distribution of data for each granitic rock in Fig. 6, this trend is noted to be nearly parallel to the line $\mathrm{AB}$, when the $\mathrm{Sr}$ content is greater than about $200 \mathrm{ppm}$. The trend becomes steep toward the lower right corner of the diagram with the decrease of the Sr content. With reference to this variation trend, it is found that the granites having high $\mathrm{Rb} / \mathrm{Sr}$ ratios like the Yatsushiro, the Amami-oshima and the Minami-osumi granites are regarded to represent more differentiated facies of granitic magmas.

If the andesitic crust model proposed by TAYLOR (1968) is admitted again, the andesitic primary crustal material, which, in turn, can give rise to a granitic magma, should have a $\mathrm{Rb} / \mathrm{Sr}$ ratio close to the mean abundance ratio of $\mathrm{Rb}$ to $\mathrm{Sr}$ in the crust, which is shown by the line $\mathrm{CD}$ in Fig. 6. The close association of data for the Funastu, the Itoshima, the Haki and the Sawara granitic rocks with the line $\mathrm{CD}$ indicates that these granitic rocks present the chemical composition close to the source andesitic materials.

The data apart far from the line $\mathrm{CD}$ to the upper left side may be regarded to represent residual facies of granitic magmas. Therefore it may be said that 


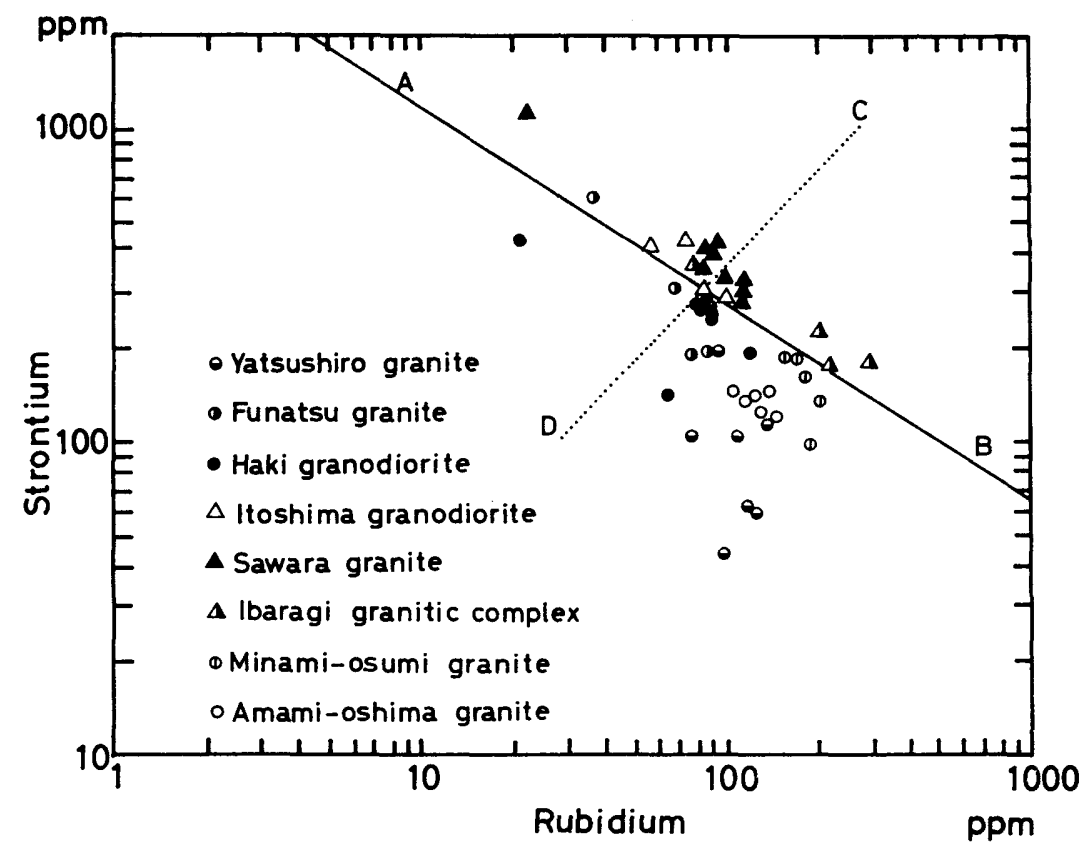

Fig. 6. Rubidium and strontium contents in granites from Southwest Japan. The line $\mathrm{CD}$ represents the mean $\mathrm{Rb} / \mathrm{Sr}$ ratio of the continental crust. The line $\mathrm{AB}$ distinguishes between two groups of the granitic rocks.

the composition of the source material for a suite of granitic rocks lying on the apparent growth line is somewhere on the line $\mathrm{CD}$ of the left side of the line $\mathrm{AB}$, while chemical compositions of the source materials for other granitic rocks may be close to the mean composition of the Sawara and the Itoshima granitic rocks.

Then it follows that the discrimination of the two types among the granitic rocks is not a problem of the magmatic differentiation of a granitic magma, but a problem concerning the formation of a source material for a granite.

Through these discussions in terms of the $\mathrm{Rb} / \mathrm{Sr}$ ratio, it may be concluded that a suite of granitic rocks lying on the apparent growth line has been derived from the common source material. In connection with this conclusion, it should be noticed that the granites of this suite are separated from one another for a great geographical distances along the Japanese Islands and the Ryukyu Islands. In addition to this, some of these granitic rocks are distributed in different tectonic positions in the geology of the Japanese Islands. For instance, the Funatsu granitic rock is in the Hida metamorphic belt, the Haki granodiorite in the Inner Zone of Southwest Japan, the Minami-osumi granite in the southern subbelt of the Outer Zone of Southwest Japan, the Amami-oshima granite in the Ryukyu Islands and the Yatsushiro granite in the Kurosegawa Tectonic Belt in the Outer Zone of Southwest Japan. 


\section{Petrogenetic Implications of Rubidium and Strontium Contents in Volcanic Rocks}

\section{(1) Petrogenetic implications of the partition relations}

The most important parameter in the variation of $\mathrm{Rb}$ and $\mathrm{Sr}$ concentrations during the magmatic differentiation is a partition coefficient between a liquid phase and minerals crystallizing from the liquid. Since ions of $\mathrm{Rb}^{+}$have a large ionic radius ratio to oxygen, the ions are hardly incorporated into the crystal structures of olivine, pyroxene, garnet and hornblende. Therefore $\mathrm{Rb}$ is concentrated into the liquid, when these minerals are in equilibrium with the liquid.

Ions of $\mathrm{Sr}^{2+}$ have an ionic radius ratio to oxygen of 0.81 (SHANNon and Prewit T, 1969), therefore the ions tend to occupy the 8 coordinated site by oxygen, while ions of $\mathrm{Ca}^{2+}$ occupy both 8 and 6 coordinated sites. Therefore strontium ions substitute few calcium ions in pyroxene and hornblende structures, but are concentrated in plagioclase substituting calcium ions in the 8 coordinated site. Then $\mathrm{Sr}$ is enriched in the liquid, when the liquidus phase is olivine, pyroxene, garnet and hornblende. Sr, however, may be depleted in the liquid, when plagioclase appears as the liquidus phase in the liquid.

\section{(2) Partition relations of rubidium and strontium between phenocrysts and the coexisting groundmass}

Selected examples of the partitioning relation of $\mathrm{Rb}$ and $\mathrm{Sr}$ between phenocrysts and the coexisting groundmass in volcanic rocks reported by Philpotss and Schnetzler (1970) are shown in the log Sr vs. log Rb diagram of Fig. 7. A thin line connecting a mineral and the groundmass is a trace of change of $\mathrm{Rb}$ and $\mathrm{Sr}$ concentrations, when the mineral and the groundmass connected by the line are mixed in various proportions. An arrow on the extension of the line on the groundmass side shows a fractionation trend of the residual liquid of the groundmass composition, when the mineral on the opposite side of the line is separated from the groundmass.

It is found from Fig. 7 that both concentrations of $\mathrm{Rb}$ and $\mathrm{Sr}$ in the residual liquid increase simultaneously without any significant increase of the $\mathrm{Rb} / \mathrm{Sr}$ ratio, when those minerals of olivine, both ortho- and clino-pyroxenes, garnet and hornblende are separated from a magma. When crystals of plagioclase are separated, the concentration of $\mathrm{Rb}$ increases, and that of $\mathrm{Sr}$ decreases in the residual magma. Therefore the $\mathrm{Rb} / \mathrm{Sr}$ ratio of the residual magma is steeply increased. The same is applied for potassium feldspar. When crystals of mica are separated, the $\mathrm{Rb} / \mathrm{Sr}$ ratio decreases and the residual magma is depleted in $\mathrm{Rb}$ with the proceeding of the crystallization of mica.

Therefore products of the fractional crystallization at a deeper level in the 


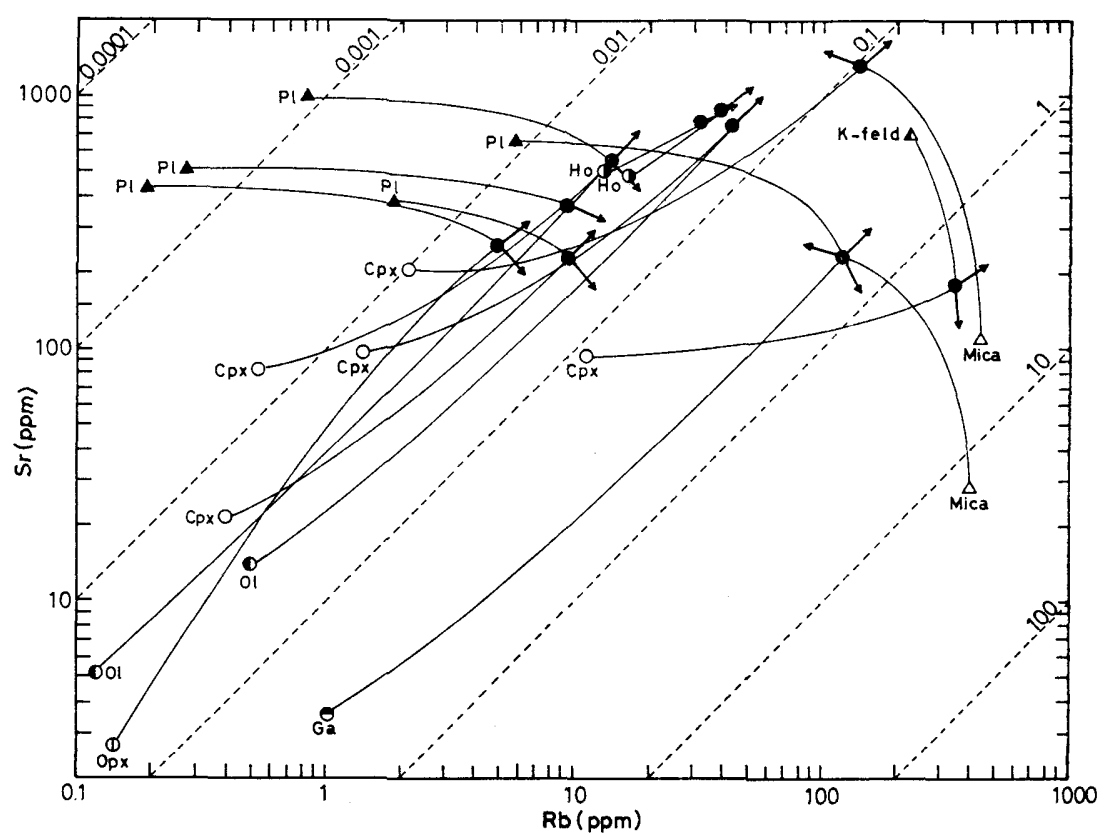

Fig. 7. Partition relations between phenocrystic minerals and the coexisting groundmass of volcanic rocks. Data are derived from Philpotts and Schnetzler (1970). Solid circles show compositions of the groundmass. Pl: plagioclase, Ho: hornblende, $\mathrm{Cpx}$ : clinopyroxene, Ol: olivine, Opx: orthopyroxene, Ga: garnet, Mica: biotite. $\mathrm{K}$-feld: potassium feldspar.

mantle will be distinguished from those at an upper level in the mantle. In the former, plagioclase is not stable as a liquidus phase but garnet is stable instead, whereas, in the latter, plagioclase appears as a stable liquidus phase together with other mafic minerals in basaltic and andesitic compositions. Extents of variation of the $\mathrm{Rb} / \mathrm{Sr}$ ratio depend on these two types of the fractional crystallization. Thus, the observation of Fig. 7 are the basis for the interpretation of the variation of $\mathrm{Rb}$ and $\mathrm{Sr}$ contents or of the variation of the $\mathrm{Rb} / \mathrm{Sr}$ ratio in volcanic rocks.

When the variation of concentrations of both elements are investigated on volcanic rocks, the following behaviours of minerals crystallizing from a magma should be noticed. Although the bulk partition coefficient, which effectively dominates the variation trend of the composition of the residual magma, is a sum of products of an abundance of and a partition coefficient for minerals crystallizing from the liquid, the minerals are not always deposited in the same abundance as they formed, because minerals differ in density from one another. Specially a mean suspension time in the magma from the crystallization to the deposition of plagioclase may be significantly longer than that of mafic minerals. Therefore plagioclase in the crystalline material suspended in the magma is more abundant than that in the material crystallizing from the magma. If a time elasped from 
Table 7. Mean partition coefficients of rubidium, strontium and potassium

\begin{tabular}{lcccccccc}
\hline & 01. & Opx. & Cpx. & Gar. & Hor. & Biot. & PI. & K-feld. \\
\hline Rubidium & 0.00488 & 0.00485 & 0.0220 & 0.0085 & 0.0609 & 2.14 & 0.0512 & 0.66 \\
Strontium & 0.00554 & 0.0176 & 0.104 & 0.0154 & 0.170 & 0.04 & 1.49 & 5.82 \\
Potassium & 0.00611 & 0.0131 & 0.0268 & 0.0198 & 0.309 & 2.48 & 0.155 & 1.49 \\
\hline
\end{tabular}

* These partition coefficients are for sodiic plagioclase. Ol: olivine, Opx: orthopyroxene, Cpx: clinopyroxene, Gar: garnet, Hor: hornblende, Biot: biotite, P1: plagioclase, $\mathrm{K}-\mathrm{Feld}$ : potassium feldspar.

the begining of the crystallization of plagioclase is long enough, the rates of the crystallization and the deposition of plagioclase crystals get a stationary state, under which the abundance of minerals being deposited would become the same proportion among minerals being crystallized. The rate of the deposition of plagioclase crystals is accelerated by the increase of the amount suspended in the magma and of crystal grain size of the plagioclase. Then the begining of the decrease of $\mathrm{Sr}$ content in the residual material may be significantly delayed from the begining of the crystallization of plagiocase. Therefore the presence of plagioclase crystals in volcanic rocks does not always mean that the Sr content in these volcanic rocks is decreased significantly by the crystallization of plagioclase.

When we infer more precisely the variation of both concentrations, numerical values of the partition coefficients of both elements are needed. Numerical values of these partition coefficients for various minerals listed in Table 7 are geometrical means of those reported by Onuma et al. (1968), Higuchi and NAGASAwA (1969), Griffin and Murthy (1969), Berin and Henderson (1969), Philpotts and Schnetzler (1970), Nagasawa and Schnetzler (1971) and Goodman (1972).

\section{(3) The mean $\operatorname{Sr}(87 / 86)$ ratio and the mean concentrations of rubi- dium and strontium in OFB}

In addition to these partition coefficients, a measure is needed for the judgment whether a volcanic rock in question is contaminated by and/or derived from a sialic crustal material. A strontium isotope ratio is the most available and effective as the measure. A criterion of the measure is the mean $\operatorname{Sr}(87 / 86)$ ratio of the upper mantle material from which the most of igneous rocks have been believed to be originated.

OFB, which are enormous in volume, homogeneous in isotopic composition, and extremely low in alkali contents, have been thought to be derived by partial melting of a great amount of the upper mantle material (GAST, 1968).

An isotopic fractionation of $\mathrm{Sr}$ during magmatic differentiations has been believed to be in the order of value far below an error of the isotopic measurement. Therefore $\mathrm{Sr}(87 / 86)$ ratios of OFB represent the mean strontium isotopic 


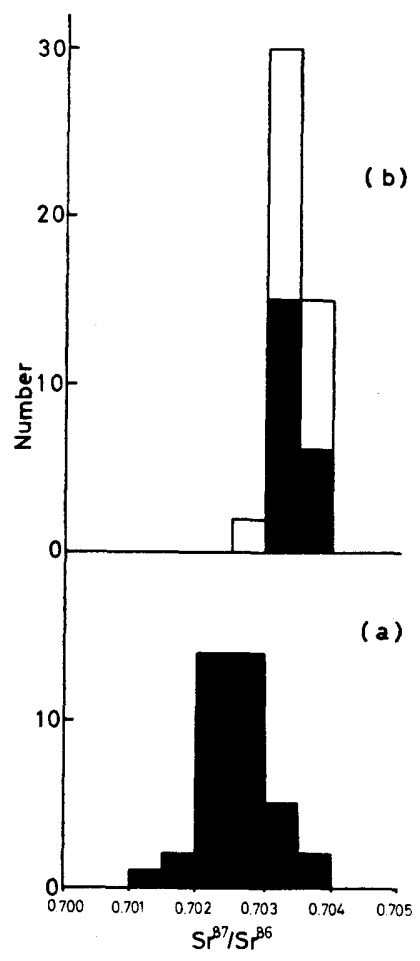

Fig. 8. The histogram of $\operatorname{Sr}(87 / 86)$ ratios of OFB (a) and recent volcanic rocks (b). The shaded areas represent basaltic volcanic rocks and the blank area represents andesitic volcanic rocks.

ratio of the upper mantle material. A frequency distribution of $\mathrm{Sr}(87 / 86)$ ratios of OFB is very simple (Fig. 8), being limited in the range from 0.701 to 0.704 with the arithmetic mean of $0.70266 \pm 0.00101$ (twice of the standard deviation) (TAтsumoto et al., 1969; CANN, 1970; Hedge and Peterman, 1970; Kay et al., 1970; Hart et al., 1972; Subbarao, 1972). Then the ratio of $0.70266 \pm 0.00101$ is used as the criterion of the measure.

Next to these two major parameters, the essentially important is the criterion of the $\mathrm{Rb} / \mathrm{Sr}$ ratio. The $\mathrm{Rb} / \mathrm{Sr}$ ratio of OFB will be also used as a reference point.

A frequency distribution of available $\mathrm{Rb} / \mathrm{Sr}$ ratios of OFB presents a fairly fine simple modal distribution. Geometric mean of the $\mathrm{Rb} / \mathrm{Sr}$ ratios, $\mathrm{Rb}$ and $\mathrm{Sr}$ contents in OFB are $0.0177,2.29 \mathrm{ppm}$ and $129 \mathrm{ppm}$ respectively. These values are used in the later section as the reference point or the initial condition for the calculation. The source of the data of $\mathrm{Rb}$ and $\mathrm{Sr}$ content is Tatsumoto et al. (1965), Gast (1967),

Kay et al. (1970), Hart et al. (1972) and Subarao (1972).

\section{(4) Rubidium and strontium contents in volcanic rocks}

Volcanic rocks from island arcs and corresponding orogenic belts at the continental margin are classified with the $\operatorname{Sr}(87 / 86)$ ratio to observe the variation of $\mathrm{Rb}$ and $\mathrm{Sr}$ contents resulted from the contamination of a sialic material, into the following four groups, 0.7017-0.7037, 0.7038-0.7047, 0.7048-0.7057 and more than 0.7058 . The range of the $\operatorname{Sr}(87 / 86)$ ratio for the first three groups is twice as

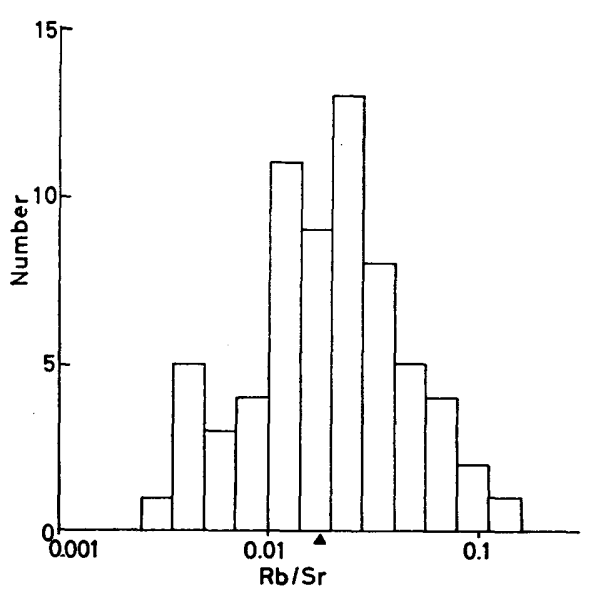

Fig. 9. The histogram of $\mathrm{Rb} / \mathrm{Sr}$ ratio of $\mathrm{OFB}$. The mean $\mathrm{Rb} / \mathrm{Sr}$ ratio (triangle) is 0.0177 . 


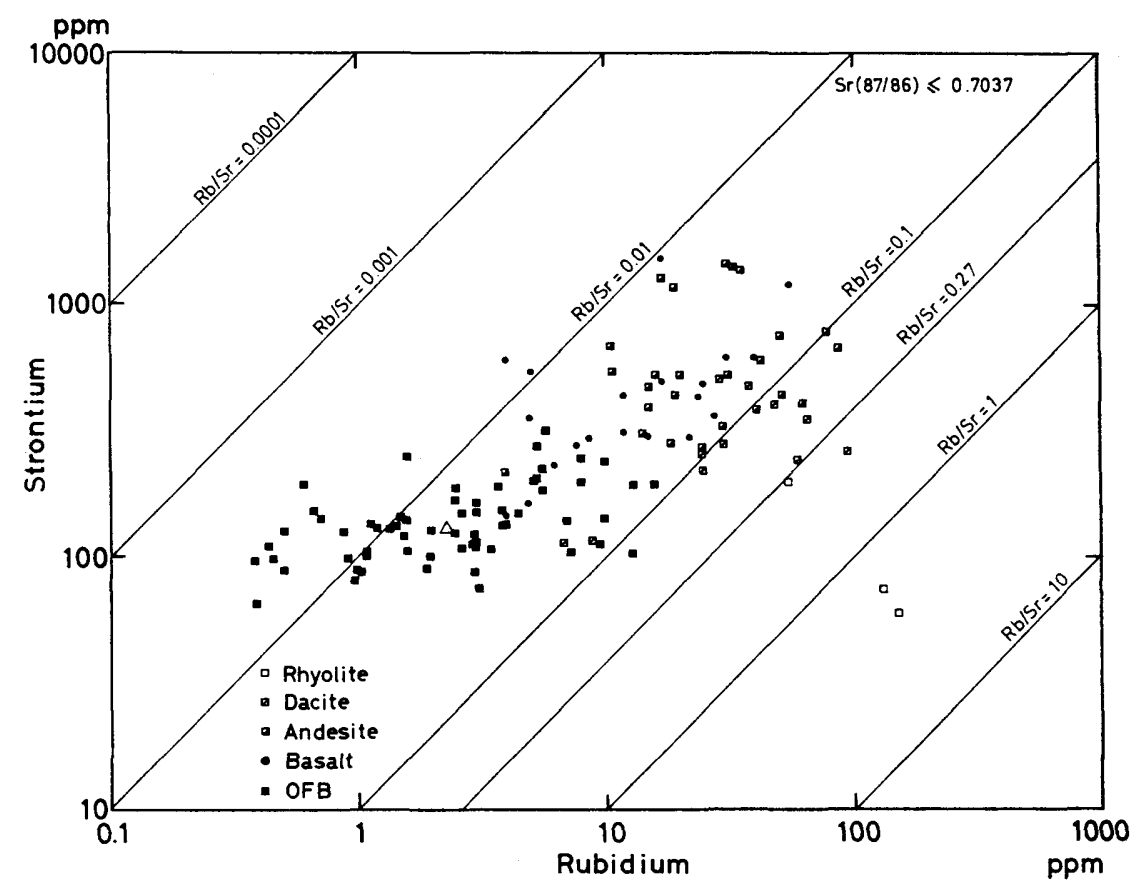

Fig. 10. Rubidium and strontium contents in OFB and recent volcanic rocks with $\operatorname{Sr}(87 / 86)$ ratios less than 0.7037 . The blank triangle represents the mean com. position of OFB.

much as the standard deviation of the $\mathrm{Sr}(87 / 86)$ ratios of OFB. The sources of data for volcanic rocks are Hedge (1966), Ewart and Stipp (1968), Pushkar (1968), Hedge and Knight (1969), Gill (1970), Hedge et al. (1970), Peterman et al. (1970), Donnelly et al. (1971), Hedge and Lewis (1971) and Pushkar et al. (1973). $\mathrm{Rb}$ and $\mathrm{Sr}$ contents in volcanic rocks of these four groups are shown in Figs. 10 to 13 respectively. $\operatorname{Sr}(87 / 86)$ ratios of the volcanic rocks plotted in Fig. 10 are within the range of the $\operatorname{Sr}(87 / 86)$ ratios of OFB. In other words, no contamination effect of the old sialic material contributes to the variation of concentrations of both elements. The degree of the contamination with the sialic material is assumed to increase with the increase of the $\operatorname{Sr}(87 / 86)$ ratio of the volcanic rocks. Thus, the arrangement of Figs 10 to 13 is in the order of increasing degree of the contamination. The following facts are noticed by the observation through these figures.

a) The $\mathrm{Sr}$ content in OFB is limited in the range of 70 to $300 \mathrm{ppm}$ and is almost constant independently of the variation of the $\mathrm{Rb}$ content. The $\mathrm{Rb}$ content ranges widely from 0.4 to $15 \mathrm{ppm}$. But the distribution of the $\mathrm{Rb}$ contents in Fig. 10 is symmetrical to the mean composition of OFB, which is shown with a triangle in Fig. 10. 


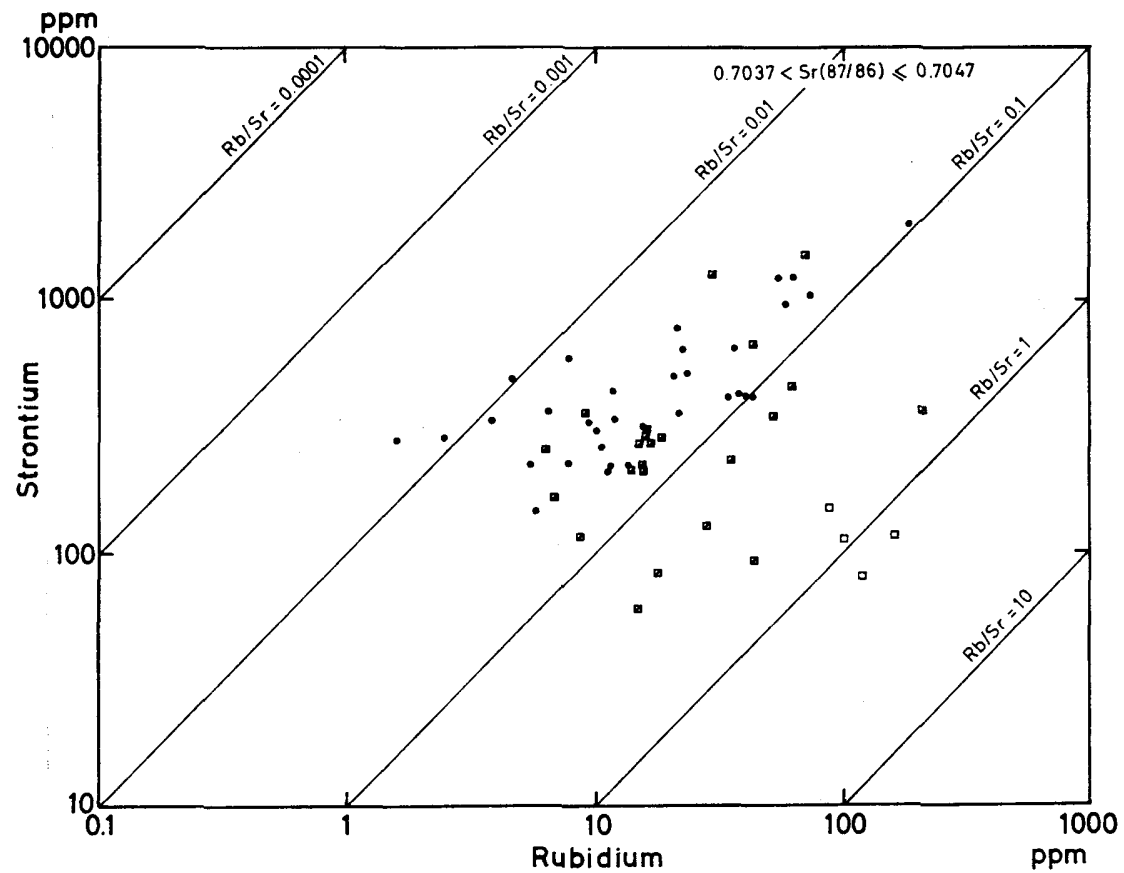

Fig. 11. Rubidium and strontium contents in recent volcanic rocks wite $\operatorname{Sr}(87 / 86)$ ratios between 0.7038 and 0.7047 . Marks are the same as those of Fig. 10 .

b) With respect to both $\mathrm{Rb}$ and $\mathrm{Sr}$ contents, the distinction is almost imposible between basalts and andesites whose $\mathrm{Sr}(87 / 86)$ ratios are included in the range of OFB.

c) In reference to the partition relation between minerals and the coexisting liquid, the andesites and the basalts are distributed nearly parallel to the line of the constant $\mathrm{Rb} / \mathrm{Sr}$ ratio, with $\mathrm{OFB}$ at the end of low concentrations of $\mathrm{Rb}$ and Sr (Fig. 10). This indicates that these volcanic rocks and OFB were connected by the magmatic differentiation at the deeper part of the mantle where plagioclase was not stable.

d) The relation on $\mathrm{Rb}$ and $\mathrm{Sr}$ contents between the basalts plus the andesites, and the dacites plus the rhyolites (Fig. 10) indicates that the dacites and the rhyolites are produced by the fractional crystallization from andesitic or basaltic magmas under low pressure conditions, under which plagioclase is stable instead of garnet.

e) The range of andesites and dacites, taking notice the higher $\mathrm{Rb} / \mathrm{Sr}$ limits of these two groups of the volcanic rocks, move toward the right side of the figures and $\mathrm{Sr}$ contents are almost constant or tend to decrease in a small extent with the increase of the $\operatorname{Sr}(87 / 86)$ ratio, while the ranges of the basalts and the rhyolites remain almost constant independently of the increase of the $\operatorname{Sr}(87 / 86)$ ratio. 


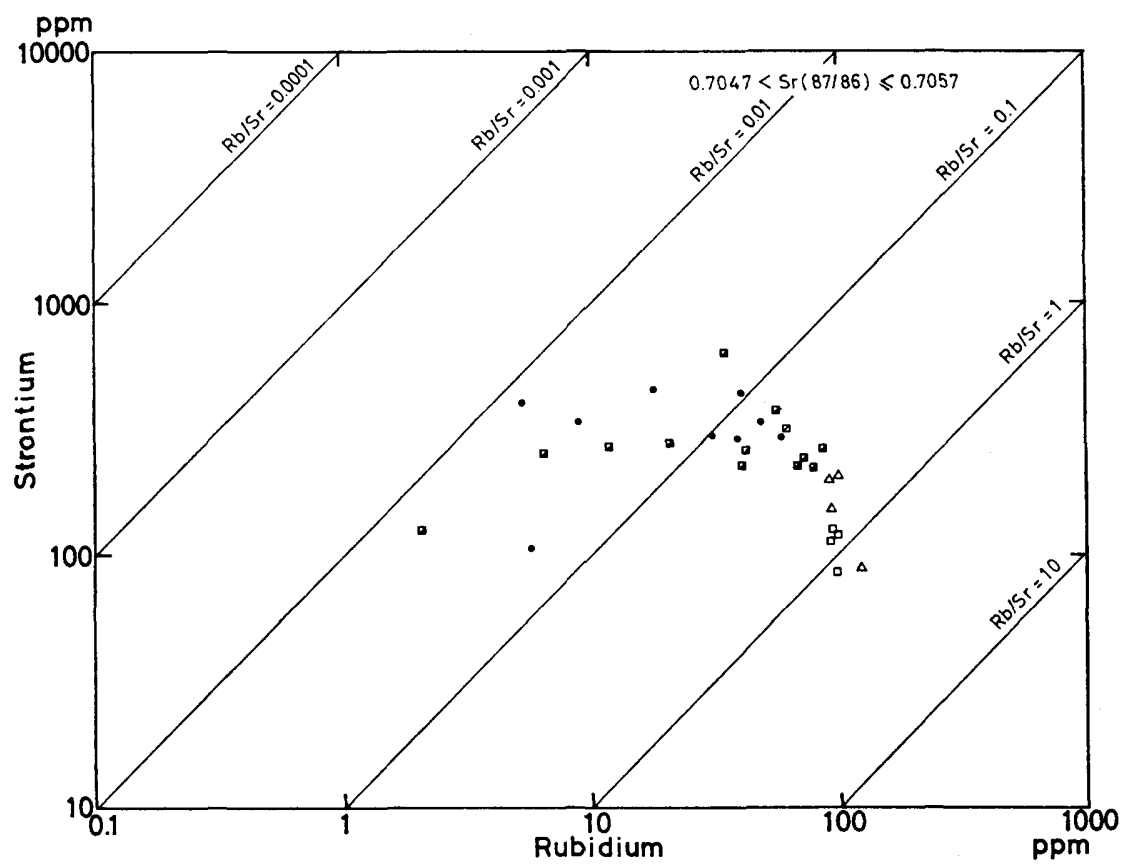

Fig. 12. Rubidium and strontium contents in recent volcanic rocks with $\operatorname{Sr}(87 / 86)$ ratios between 0.7048 and 0.7057 . Small triangles represent compositions of ignimbrites. Other marks are the same as those of Fig. 10.

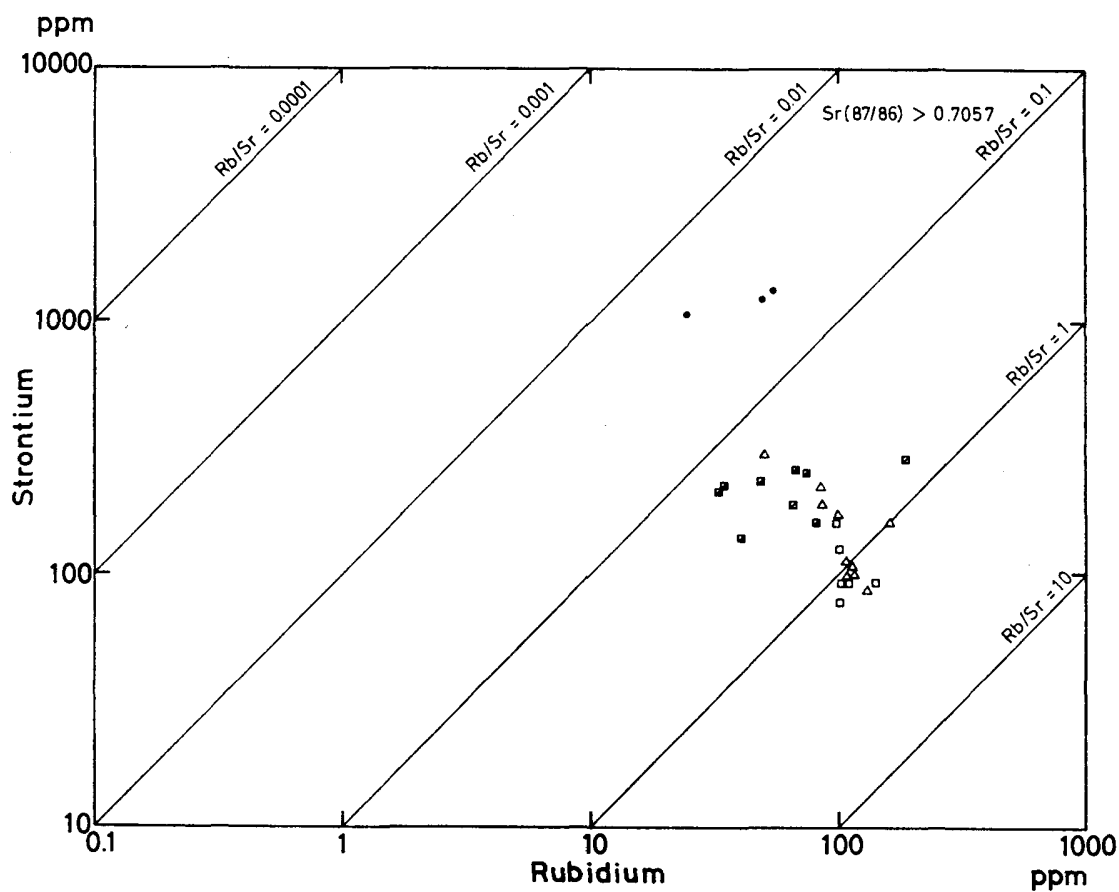

Fig. 13. Rubidium and strontium contents in recent volcanic rocks with $\mathrm{Sr}(87 / 86)$ ratios greater than 0.7057 . Small triangles represent the composition of ignimbrites. Other marks are the same as those of Fig. 10. 
f) The mean crustal $\mathrm{Rb} / \mathrm{Sr}$ ratio is about 0.27 , being far above the $\mathrm{Rb} / \mathrm{Sr}$ ratios of the andesites, the basalts, OFB and the upper mantle material. Accordingly the continental crust must have been produced by a magmatic process under low pressure conditions.

\section{(5) The variation of $\mathrm{Rb} / \mathrm{Sr}$ ratios in volcanic rocks}

$\mathrm{Rb} / \mathrm{Sr}$ ratios of volcanic rocks give also some important informations on the petrogenesis of these volcanic rocks. In this case too, the mean $\mathrm{Rb} / \mathrm{Sr}$ ratio of $\mathrm{OFB}$ is adopted as the reference point. The variation of the frequency distribution of the $\mathrm{Rb} / \mathrm{Sr}$ ratios in the volcanic rocks, which are the same as those plotted in Figs. 10 to 13 , are shown in Figs. 14 to 17 . The followings may be read from these figures.

a) The frequency distribution of the andesites of low strontium isotope ratios shows a bimodal character with two distinct peaks of about 0.023 and $0.048-0.068$ of the $\mathrm{Rb} / \mathrm{Sr}$ ratio. This indicates the presence of two groups in these volcanic rocks. The same pattern of the distribution is found also in that of the basalts of low strontium isotope ratios. The peak of the lower side of the $\mathrm{Rb} / \mathrm{Sr}$ ratio of both basalts and andesites corresponds to the peak of OFB (Fig. 9). The peak of the higher side of the $\mathrm{Rb} / \mathrm{Sr}$ ratio is enhanced with the increase of the $\mathrm{Sr}(87 / 86)$ ratio from $0.7017-0.7037$ to $0.7038-0.7047$.

b) $\mathrm{The} \mathrm{Rb} / \mathrm{Sr}$ ratios of basalts slightly increase with the increase of the $\mathrm{Sr}(87 / 86)$ ratio. The abundance of the basalts, however, diminished with the increase of the $\mathrm{Sr}(87 / 86)$ ratio. The histogram of the $\mathrm{Rb} / \mathrm{Sr}$ ratio of the basalts is terminated sharply at the higher side of the ratio.

c) Variation of the $\mathrm{Rb} / \mathrm{Sr}$ ratio and of the abundance of andesites with the increase of the $\operatorname{Sr}(87 / 86)$ ratio are almost the same as these of the basalts. It should be, however, noticed that the extent of the increase of the mean $\mathrm{Rb} / \mathrm{Sr}$ ratio of each group of the andesites with the increase of the $\operatorname{Sr}(87 / 86)$ ratio seems to be more distinct.

d) The $\mathrm{Rb} / \mathrm{Sr}$ ratio of the dacites and the ignimbrites increases systematically from about 0.08 to 1 , several times as large as the continental average, with the increase of the $\operatorname{Sr}(87 / 86)$ ratio. The abundance of these volcanic rocks does not diminish with the increase of the $\operatorname{Sr}(87 / 86)$ ratio.

e) The $\mathrm{Rb} / \mathrm{Sr}$ ratios of the rhyolites do not change significantly, converging at about 1.2 with the increase of the $\operatorname{Sr}(87 / 86)$ ratio. This convergent value of the $\mathrm{Rb} / \mathrm{Sr}$ ratio coincides with the highest value attained by the dacites and the ignimbrites through the contamination of the sialic material. The abundance of the rhyolites also has a tendency to increase with the increase of the $\operatorname{Sr}(87 / 86)$ ratio. 


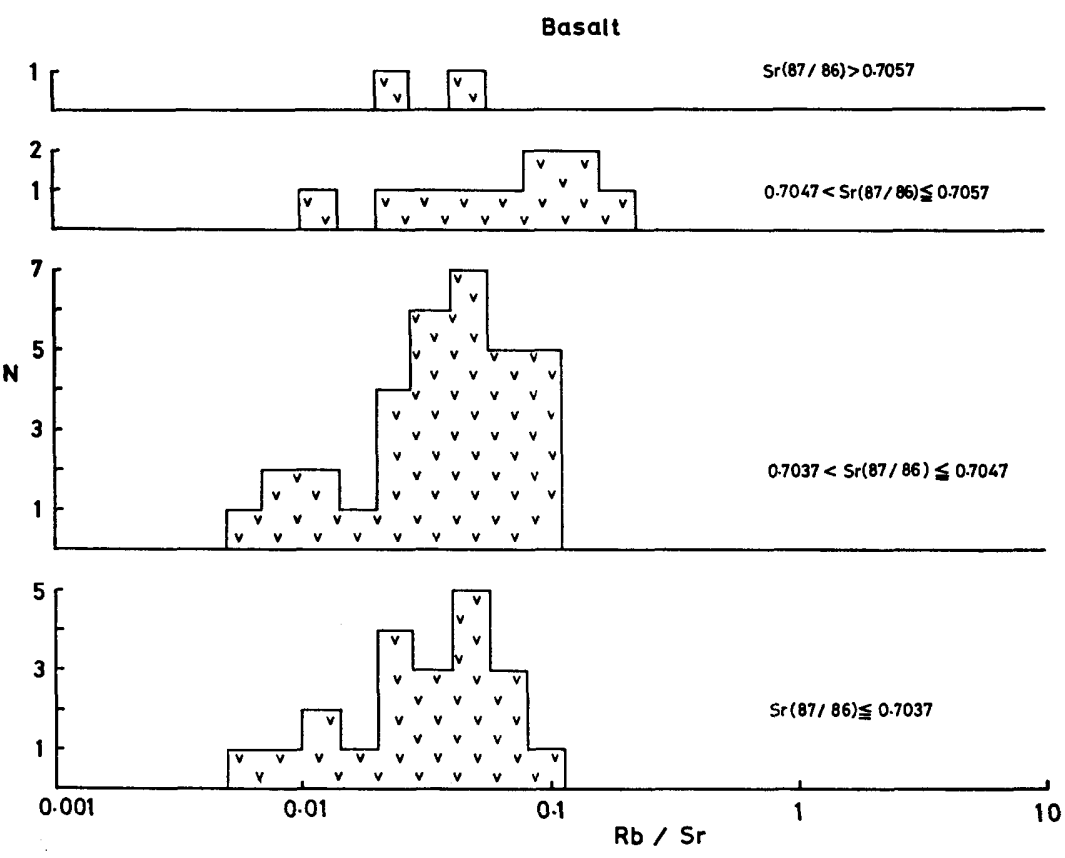

Fig. 14. Frequency distributions of the $\mathrm{Rb} / \mathrm{Sr}$ ratio of basaltic volcanic rocks.

\section{Andesite}
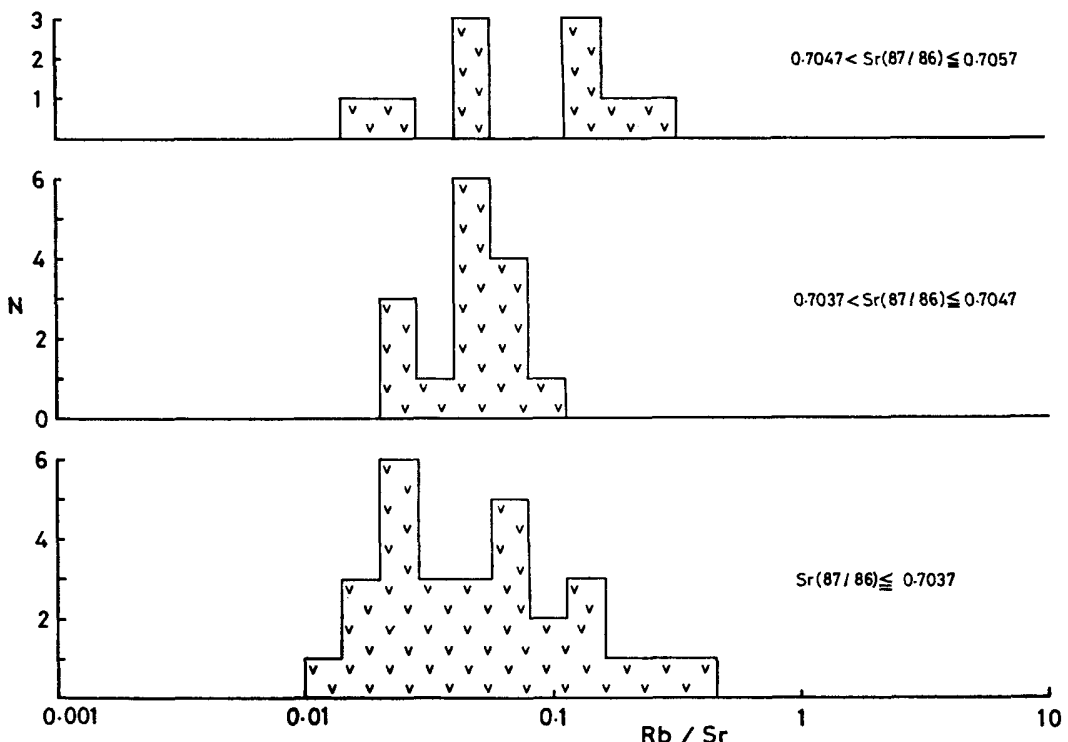

Fig. 15. Frequency distributions of the $\mathrm{Rb} / \mathrm{Sr}$ ratio of andesitic volcanic rocks. 


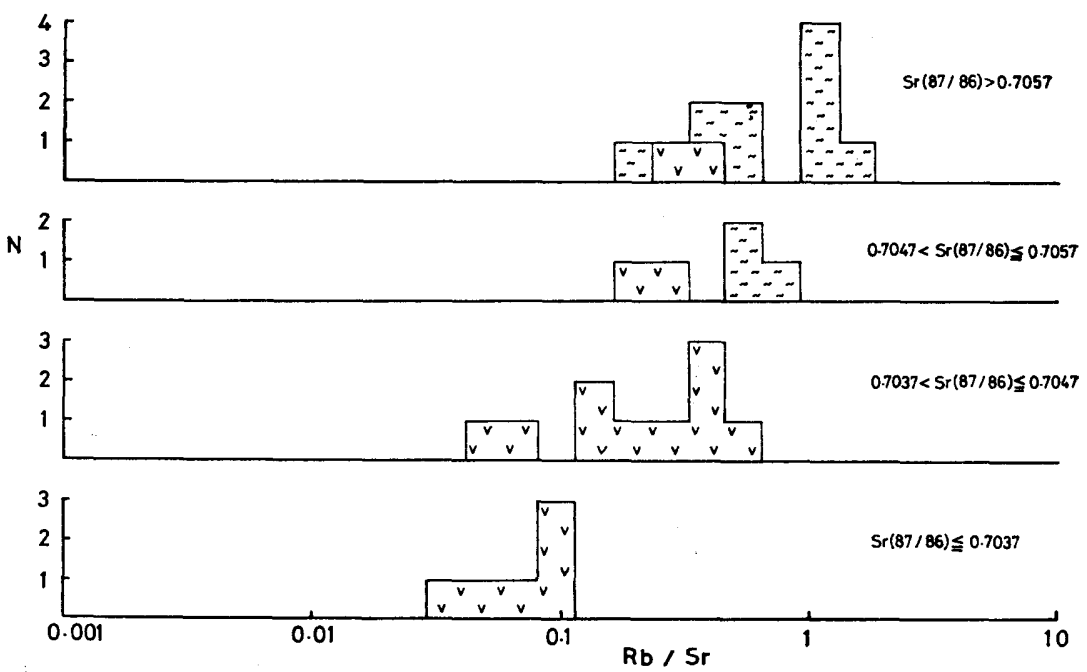

Fig. 16. Frequency distributions of the $\mathrm{Rb} / \mathrm{Sr}$ ratio of dacites and ignimbrites.
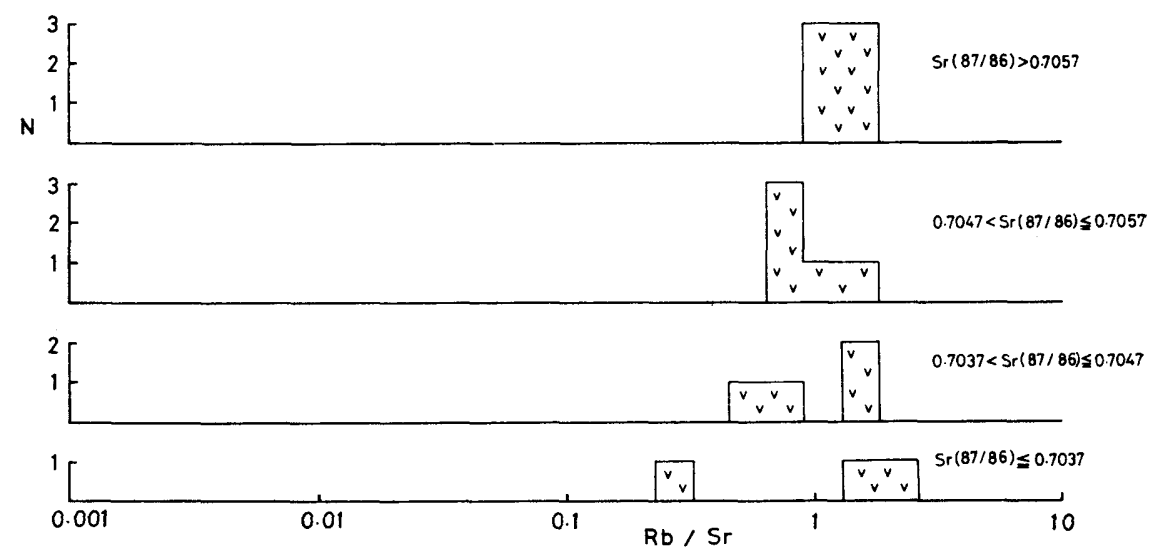

Fig. 17. Frequency distributions of the $\mathrm{Rb} / \mathrm{Sr}$ ratio of rhyolites. 


\section{(6) Petrogenetic relation between OFB and the andesites of low $\mathrm{Sr}(\mathbf{8 7} / 86)$ ratios}

With reference to the partition relations of $\mathrm{Rb}$ and $\mathrm{Sr}$ between minerals and the coexisting liquid, and admitting the convergence of the oceanic plate down into the mantle at the island arc, the relation on both $\mathrm{Rb}$ and $\mathrm{Sr}$ contents between $\mathrm{OFB}$ and the andesites of low $\mathrm{Sr}(87 / 86)$ ratios, and the coincidence of the $\mathrm{Rb} / \mathrm{Sr}$ ratio between OFB and the andesites are consistent with GreEN and Ringwood's (1968) model of derivation of an andesite from OFB in the depth of the mantle, because these two facts are sufficiently explained by the partial melting followed by the fractional crystallization of OFB under high pressure conditions.

In connection with these relations, there is a contradictory fact between $\mathrm{Sr}(87 / 86)$ ratios of $\mathrm{OFB}$ and the andesites. The $\mathrm{Sr}(87 / 86)$ ratios of the andesites and also the basalts are biased by 0.0006 toward the higher side of the variation range of the $\operatorname{Sr}(87 / 86)$ ratios of $\mathrm{OFB}$ (Fig. 8). The lower side of the variation range of these $\operatorname{Sr}(87 / 86)$ ratios is sharply limited. This difference seems to have following important meaning on the genesis of the basalts and the andesites at the island arc. Although a definite conclusion could not be drawn in this paper, two alternative explanotions are possible for this isotopic difference. The first is that all of the volcanic rocks in the island arc are contaminated by the sialic material during the ascent through the sialic crust. The second is that a small amount of sediments on the floor of the ocean is trapped in OFB as the oceanic plate converges into the mantle or that scraps of the sialic crust are dragged into the mantle on the continental side of the trench by the downward movement of the oceanic plate.

\section{(7) The limitation of the chemical composition of the lower crust}

The variation of the $\mathrm{Rb} / \mathrm{Sr}$ ratio may be regarded to reflect the major chemical composition of a material contaminating the volcanic rocks. The regularlity of the variation among different island arcs indicates that this material has a specific $\mathrm{Rb} / \mathrm{Sr}$ ratio and a definite major chemical composition, which are constant regardless of its position in the island arc and also do not vary among island arcs. In other words, the regularlity limits the chemical composition of the material which contaminates the magma at the lower part of crust where the potential ability of the magma to melt the material is highest.

From close inspection by trial and error, regarding the contamination as a magmatic process analogous to the zone melting, it is concluded that an andesitic model of the material with a $\mathrm{Rb} / \mathrm{Sr}$ ratio close to the mean of the continental crust can sufficiently explain the variation of the $\mathrm{Rb} / \mathrm{Sr}$ ratio and that of the abundance of basalts, andesites, dacites plus ignimbrites and rhyolites. Namely, the material should be andesitic or somewhat more acid and could not exceed a 
dacitic composition toward acid side

\section{Principal Equations in Rubidium and Strontium Concentrations}

Concentrations of both elements of $\mathrm{Rb}$ and $\mathrm{Sr}$ in an igneous rock depend on a source material and a process through which the igneous rock is produced from the source material. The relation between the magmatic process and the variation of $\mathrm{Rb}$ and $\mathrm{Sr}$ concentrations in a magmatic melt should be known to trace the process and to obtain a knowledge about the source material from $\mathrm{Rb}$ and $\mathrm{Sr}$ contents in the igneous rock. For this purpose, principal equations in $\mathrm{Rb}$ and $\mathrm{Sr}$ concentrations maintained during the following three main magmatic differentiations are introduced and then used as a basis of the later discussions.

\section{(1) Equilibrium partial melting}

When crystals of a single phase exist in equilibrium with a liquid, let the $\mathrm{Rb}$ concentration in the crystals and the liquid be $\mathrm{C}_{\mathrm{xal}}^{\mathrm{Rb}}$ and $\mathrm{C}_{l}^{\mathrm{Rb}}$ respectively. $\mathrm{A}$ partition coefficient of $\mathrm{Rb}$ between the crystals and the liquid is defined by

$$
r^{\mathrm{Rb}}=\mathrm{C}_{\mathrm{xal}}^{\mathrm{Rb}} / \mathrm{C}_{l}^{\mathrm{Rb}}
$$

When the fraction of the liquid is $F$, there exists the following relation among the fraction of the liquid and the concentrations of $\mathrm{Rb}$ in the liquid and the crystals.

$$
\mathrm{C}_{\mathrm{xal}}^{\mathrm{Rb}}(1-\mathrm{F})+\mathrm{C}_{l}^{\mathrm{Rb}} \mathrm{F}=\mathrm{C}_{0}^{\mathrm{Rb}},
$$

where $\mathrm{C}_{0}^{\mathrm{Rb}}$ is the concentration of $\mathrm{Rb}$ in the crystals before the melting.

Substituting the equation (2) by the equation (1), the following relation is obtained.

$$
\mathrm{C}_{l}^{\mathrm{Rb}}\left\{\gamma^{\mathrm{Rb}}(1-\mathrm{F})+\mathrm{F}\right\}=\mathrm{C}_{0}^{\mathrm{Rb}} .
$$

If both concentrations of $\mathrm{Rb}$ and $\mathrm{Sr}$ are extremely low, and these elements behave independently during the partial melting, the same equation as the equation (3) will be obtained for Sr.

$$
\mathrm{C}_{l}^{\mathrm{Sr}}\left\{r^{\mathrm{Sr}}(1-\mathrm{F})+\mathrm{F}\right\}=\mathrm{C}_{0}^{\mathrm{Sr}} .
$$

Eliminating $\mathrm{F}$ in the equations (3) and (4),

$$
\frac{\mathrm{C}_{0}^{\mathrm{Sr}}-\gamma^{\mathrm{Sr}} \mathrm{C}_{l}^{\mathrm{Sr}}}{\mathrm{C}_{l}^{\mathrm{Sr}}\left(1-\gamma^{\mathrm{Sr}}\right)}=\frac{\mathrm{C}_{0}^{\mathrm{Rb}}-\gamma^{\mathrm{Rb}} \mathrm{C}_{l}^{\mathrm{Rb}}}{\mathrm{C}_{l}^{\mathrm{Rb}}\left(1-\gamma^{\mathrm{Rb}}\right)}
$$

is obtained. This is the relation between $\mathrm{Rb}$ and $\mathrm{Sr}$ concentrations in the equilibrium partial melting.

The relative variation of $\mathrm{Sr}$ concentration in the liquid is

$$
\frac{\mathrm{dC}_{l}^{\mathrm{Sr}}}{\mathrm{C}_{l}^{\mathrm{Sr}}}=\frac{\mathrm{C}_{0}^{\mathrm{Rb}}\left(1-r^{\mathrm{Sr}}\right) \mathrm{dC}_{l}^{\mathrm{Rb}}}{\mathrm{C}_{l}^{\mathrm{Rb}}\left\{\mathrm{C}_{0}^{\mathrm{Rb}}\left(1-r^{\mathrm{Sr}}\right)+\mathrm{C}_{l}^{\mathrm{Rb}}\left(\gamma^{\mathrm{Sr}}-\gamma^{\mathrm{Rb}}\right)\right\}}
$$

Values of the partition coefficients of $\mathrm{Rb}$ and $\mathrm{Sr}$ for some mafic minerals are so small that the difference between both partition coefficients approximates to zero. Then the equation (6) is expressed as follows. 


$$
\frac{\mathrm{dC}_{l}^{\mathrm{Sr}}}{\mathrm{C}_{l}^{\mathrm{Sr}}}=\frac{\mathrm{dC}_{l}^{\mathrm{Rb}}}{\mathrm{C}_{l}^{\mathrm{Rb}}} \quad \text { or } \quad \frac{\mathrm{d} \log \mathrm{C}_{l}^{\mathrm{Sr}}}{\mathrm{d} \log \mathrm{C}_{l}^{\mathrm{Rb}}}=1 .
$$

The equation (7) gives the relationship of variation of both $\mathrm{Rb}$ and $\mathrm{Sr}$ concentrations in the liquid at high pressures, at which plagioclase is not stable. This equation means that the high pressure partial melting cannot increase the $\mathrm{Rb} / \mathrm{Sr}$ ratio of the liquid.

\section{(2) Fractional crystallization}

The variation of concentration of $\mathrm{Rb}$ in the liquid during the fractional crystallization is expressed as follows,

$$
\mathrm{C}_{l}^{\mathrm{Rb}}\left(1-r^{\mathrm{Rb}}\right) \mathrm{dx}=(\mathrm{M}-\mathrm{x}) \mathrm{dC}_{l}^{\mathrm{Rb}},
$$

where $\mathrm{x}$ is an amount of crystals, and $\mathrm{M}$ is an amount of the liquid at the initial state of the crystallization. Integrating the equation (8),

$$
\log \frac{\mathrm{C}_{l}^{\mathrm{Rb}}}{\mathrm{C}_{0}^{\mathrm{Rb}}}=\left(\gamma^{\mathrm{Rb}}-1\right) \log \frac{\mathrm{M}-\mathrm{x}}{\mathrm{M}}
$$

is obtained, where $\mathrm{C}_{0}^{\mathrm{Rb}}$ is the concentration of $\mathrm{Rb}$ in the liquid before the crystallization. Putting $\frac{M-x}{M}$ as $F$, this equation is expressed as follows,

$$
\log \frac{\mathrm{C}_{l}^{\mathrm{Rb}}}{\mathrm{C}_{0}^{\mathrm{Rb}}}=\left(r^{\mathrm{Rb}}-1\right) \log \mathrm{F} .
$$

This is the well known Rayleigh Fractionation Law. If both elements of $\mathrm{Rb}$ and $\mathrm{Sr}$ in the same liquid behave independently, the same equation as (10) will be obtained for $\mathrm{Sr}$.

$$
\log \frac{\mathrm{C}_{l}^{\mathrm{Sr}}}{\mathrm{C}_{0}^{\mathrm{Sr}}}=\left(r^{\mathrm{Sr}}-1\right) \log \mathrm{F} .
$$

Eliminating $\mathrm{F}$ from the equations (10) and (11),

$$
\frac{r^{\mathrm{Rb}}-1}{\gamma^{\mathrm{Sr}}-1} \log \mathrm{C}_{l}^{\mathrm{Sr}}=\log \mathrm{C}_{l}^{\mathrm{Rb}}+\frac{\gamma^{\mathrm{Rb}}-1}{r^{\mathrm{Sr}}-1} \log \mathrm{C}_{0}^{\mathrm{Sr}}-\log \mathrm{C}_{0}^{\mathrm{Rb}}
$$

is obtained. This shows a relationship of concentrations of both elements in the residual liquid.

Differentiating the equation (12)

$$
\frac{\mathrm{d} \log \mathrm{C}^{\mathrm{Sr}}}{\mathrm{d} \log \mathrm{C}^{\mathrm{Rb}}}=\frac{r^{\mathrm{Sr}}-1}{r^{\mathrm{Rb}}-1}
$$

is obtained. This equation means that the logarism of $\mathrm{Sr}$ concentration changes linearly against the logarism of $\mathrm{Rb}$ concentration in the residual liquid.

Since the values of each partition coefficient of both elements for mafic minerals like olivine, ortho- and clino-pyroxenes, hornblende and garnet are negligibly small, the equation (13) is also approximately expressed as follows.

$$
\frac{\mathrm{d} \log \mathrm{C}_{l}^{\mathrm{Sr}}}{\mathrm{d} \log \mathrm{C}_{l}^{\mathrm{Rb}}}=1 \text {. }
$$

This means that the slope of the variation of concentrations of both elements is 
close to unity on the $\log \mathrm{C}_{l}^{\mathrm{Rb}}$ vs $\log \mathrm{C}_{l}^{\mathrm{Sr}}$ diagram. viz., a constant $\mathrm{Rb} / \mathrm{Sr}$ ratio.

\section{(3) Zone melting}

An increment of the concentration of $\mathrm{Rb}$ in the liquid at the position put forward by $\mathrm{dx}$ from the position $\mathrm{x}$ is given by the following equation, when an amount of the liquid $\mathrm{M}_{0}$ is held constant,

$$
\left(\mathrm{C}_{\mathrm{B}}^{\mathrm{Rb}}-\gamma^{\mathrm{Rb}} \mathrm{C}_{l}^{\mathrm{Rb}}\right) \mathrm{dx}=\mathrm{M}_{\mathbf{0}} \mathrm{dC}_{l}^{\mathrm{Rb}}
$$

where $C_{B}^{\mathrm{Rb}}$ and $\mathrm{C}_{l}^{\mathrm{Rb}}$ are concentrations of $\mathrm{Rb}$ in the melting material and in the liquid respectively. Integrating the equation (15) from $\mathrm{x}=0$ to $\mathrm{x}=\mathrm{X}$,

$$
Z=\frac{1}{r^{\mathrm{Rb}}} \log \frac{\mathrm{C}_{\mathrm{B}}^{\mathrm{Rb}}-r^{\mathrm{Rb}} \mathrm{C}_{0}^{\mathrm{Rb}}}{\mathrm{C}_{\mathrm{B}}^{\mathrm{Rb}}-\gamma^{\mathrm{Rb}} \mathrm{C}_{l}^{\mathrm{Rb}}}
$$

is obtained, where $Z$ is $X / M_{0}$ and $C_{0}^{R b}$ is the concentration of $R b$ in the initial liquid. The equalion (16) means that the concentration of $\mathrm{Rb}, \mathrm{C}_{l}^{\mathrm{Rb}}$, in the liquid zone converges into a definite concentration of $\mathrm{C}_{B}^{\mathrm{Rb}} / \gamma^{\mathrm{Rb}}$ as $Z$ increases infinitely.

$$
\lim _{\mathrm{z} \rightarrow \infty} \mathrm{C}_{l}^{\mathrm{Rb}}=\frac{\mathrm{C}_{\mathrm{B}}^{\mathrm{Rb}}}{\gamma^{\mathrm{Rb}}} \text {. }
$$

If both concentrations of $\mathrm{Rb}$ and $\mathrm{Sr}$ are so low that each of these elements behaves independently, then the following equations similar to (16) and (17) will be obtained for Sr.

$$
\begin{aligned}
& \mathrm{Z}=\frac{1}{r^{\mathrm{Sr}}} \log \frac{\mathrm{C}_{\mathrm{B}}^{\mathrm{Sr}}-\gamma^{\mathrm{Sr}} \mathrm{C}_{0}^{\mathrm{Sr}}}{\mathrm{C}_{\mathrm{B}}^{\mathrm{Sr}}-r^{\mathrm{Sr}} \mathrm{C}_{l}^{\mathrm{Sr}}} . \\
& \lim _{\mathrm{Z} \rightarrow \infty} \mathrm{C}_{l}^{\mathrm{Sr}}=\frac{\mathrm{C}_{\mathrm{B}}^{\mathrm{Sr}}}{r^{\mathrm{Sr}}} .
\end{aligned}
$$

From the equations (16) and (18), the $\mathrm{Rb} / \mathrm{Sr}$ ratio of the liquid zone is found to converge into a value which is $r^{\mathrm{Sr}} / \gamma^{\mathrm{Rb}}$ times of the $\mathrm{Rb} / \mathrm{Sr}$ ratio of the melting material.

$$
\lim _{\mathrm{z} \rightarrow \infty} \frac{\mathrm{C}_{l}^{\mathrm{Rb}}}{\mathrm{C}_{l}^{\mathrm{Sr}}}=\frac{\gamma^{\mathrm{Sr}} \mathrm{C}_{\mathrm{B}}^{\mathrm{Rb}}}{r^{\mathrm{Rb}} \mathrm{C}_{\mathrm{B}}^{\mathrm{Sr}}} .
$$

As there exist a few minerals in equilibrium with the liquid during the magmatic differentiations, bulk partition coefficient of these elements is expressed as a sum of products of an abundance $a_{i}$ of and a partition coefficient $r_{i}$ for each mineral,

$$
\left.\begin{array}{l}
\gamma_{\text {bulk }}^{\mathrm{Rb}}=\sum \mathrm{a}_{\mathrm{i}} \gamma_{1}^{\mathrm{Rb}} \\
\gamma_{b u 1 k}^{\mathrm{Sr}}=\sum \mathrm{a}_{1} \gamma_{i}^{\mathrm{Sr}}
\end{array}\right\} .
$$

When the $\mathrm{Rb} / \mathrm{Sr}$ ratios of the melting material and the liquid are expressed as $R_{B}$ and $R_{\imath}$ respectively, the $R_{\iota}$ convrges infinitely to a value of $R_{B} \cdot \gamma_{\text {bulk }}^{\mathrm{Sr}} / \gamma_{\text {bulk }}^{\mathrm{Rb}}$.

For the convenience, let $\alpha$ define as follows.

$$
\alpha=\frac{\mathrm{C}_{l}-\mathrm{C}_{0}}{\mathrm{C}_{\mathrm{B}} / \gamma-\mathrm{C}_{0}}
$$


Then the equation (16) becomes

$$
\alpha=1-\exp (-r Z)
$$

Here $\alpha$ converges infinitely to 1

As shown in the equation (23), $\alpha$ is a measure of the extent of convergence of the concentration.

If $\mathrm{Sr}(87 / 86)$ ratios of the initial liquid and the melting material are different from each other, $\operatorname{Sr}(87 / 86)$ ratio of the liquid zone varies with the proceeding of zone melting. In this case, the partition coefficient is the same for both strontium isotopes. Putting the convergent values of concentartions of both isotopes as $\mathrm{C}^{87}$ and $C^{86}$ respectively, the variation of the $\operatorname{Sr}(87 / 86)$ ratio of the liquid zone $\operatorname{Sr}(87 / 86)_{t}$ is expressed in the following form.

$$
\operatorname{Sr}(87 / 86)_{l}=\frac{\alpha\left(C^{87}-C_{0}^{87}\right)+C_{0}^{87}}{\alpha\left(C^{86}-C_{0}^{86}\right)+C_{0}^{88}},
$$

where $\mathrm{C}_{0}^{87}$ and $\mathrm{C}_{0}^{86}$ are the concentrations of both isotopes in the initial liquid. If the $\operatorname{Sr}(87 / 86)$ ratio of the melting material is higher than that of the initial liquid, then the ratio increases with the proceeding of the zone melting and ultimately converges into the ratio of the melting material. This equation may be applied to a magma being contaminated by an old sialic material.

\section{The Secondary Mantle Current beneath the Island Arc}

The recently developed plate tectonics has regarded the island are or the orogenic belt at the continental margin as a site of the mutual interaction of two rigid plates (LE PICHon et al., 1973). This hypothesis provides us with the idea of the convergence of the oceanic plate, including OFB at its top, down into the upper mantle under the island arc. Seismic activities in the mantle along the Benioff zone have been considered to be results of the mutual interaction of the two rigid plates under the island arc (IsAkes et al., 1968).

In addition, sites of recent volcanic activities in the island arc have been closely connected with the depth of the seismic zone which underlied this mobile belt. The sites of the volcanic activities are sharply bounded by the volcanic front which corresponds to the depth of about $100 \mathrm{~km}$ of the seismic zone (Sugimura, 1967; Dickinson and Hatherton, 1967; Ueda and Sugimura, 1970). Volcanism represents a sharp contrast between areas on both sides of the volcanic front, being violent on the inner side of the volcanic front, where distributes enormous volume of mostly andesitic volcanic rocks, while outside the volcanic front, there is no volcanic rock.

Thereupon, for the genesis of the andesite in the orogenic belt, GrEeN and RINGWOOD (1968) have proposed a hypothesis of a two stage model of the magmatic process through which the andesite is produced from the upper mantle material. 
This model is an idea directly linked to the hypothesis of the plate tectonics and can explain the existence and the position of the volcanic front in the island arc. The derivation of the andesite from the upper mantle material through this magmatic process has already been supported in this paper.

There are many other reports in which authers attempt to connect petrochemical characters of volcanic rocks with the depth of the seismic zone in the mantle (Kuno, 1959 and 1966; Sugimura, 1967; Hatherton and Dickinson, 1969; Dickinson, 1970; HART et al., 1970). Therefore it seems to be worthwhile to examine quantitative limits of the variation range of the $\mathrm{Rb} / \mathrm{Sr}$ ratio, and $\mathrm{Rb}$ and Sr concentrations in the andesite so formed.

\section{(1) High pressure partial melting of OFB}

Since Green and Ringwood (1968) found that at 27-36 kbs dry conditions, crystalline phase in the melting interval are composed of garnet and clinopyroxene in tholeiite, basaltic andesite and andesite, the calculation of $\mathrm{Rb}$ and $\mathrm{Sr}$ concentrations has carried out on these two minerals, following the equations (3) and (4). The partition coefficients used are listed in Table 7. The initial composition of the material before the melting is $2.29 \mathrm{ppm}$ of $\mathrm{Rb}, 129 \mathrm{ppm}$ of $\mathrm{Sr}$ and 0.0177 of

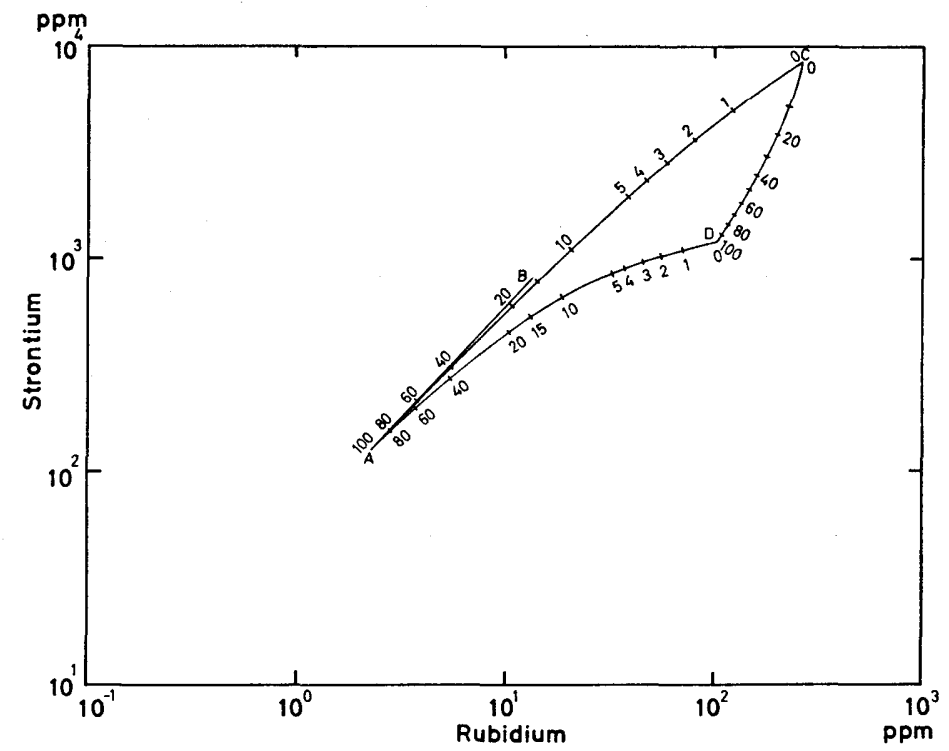

Fig. 18. Variation trends of composition of a liquid produced by the high pressure partial melting from a material with the mean composition of OFB. The point $A$ is the mean composition of OFB. Lines $A C$ and $A D$ are the trace of composition of the liquid, when the residuum is assumed to be composed of only one phase of garnet and clinopyroxene respectively. Numbers on these two lines show the proportion of the liquid to the source material. Numbers on the line $C D$ represent the proportion of clinopyroxene to garnet in the source material. The line $A B$ represents the simplified composition of the high pressure derivatives from OFB. 
the $\mathrm{Rb} / \mathrm{Sr}$ ratio.

The results are shown in Fig. 18. The point A in Fig. 18 is the mean composition of $\mathrm{OFB}$, and the lines $\mathrm{AC}$ and $\mathrm{AD}$ are traces of the composition of the liquid, when crystals of garnet and clinopyroxene are left in the residuum respectively. A number on these two lines is a percentage of the liquid fraction. That on the line $\mathrm{CD}$ is a percentage abundance of clinopyroxene in the residuum, when the liquid fraction is zero percent.

Since the variation of the concentrations of $\mathrm{Rb}$ and $\mathrm{Sr}$ in the liquid depends on the abundance of garnet and that of clinopyroxene in the residuum, the composition of the liquid fraction is limited in the field bounded by the lines AC, $\mathrm{CD}$ and DA.

\section{(2) Fractional crystallization under high pressure conditions}

The fractional crystallization under high pressure conditions is considered here, assuming that an initial liquid ( $F$ in Fig. 19) for the crystallization is produced by 60 percent equilibrium partial melting from OFB. This assignment of the melting proportion is rather arbitrary. The calculation of $\mathrm{Rb}$ and $\mathrm{Sr}$ concentrations in the residual liquid is carried out following the equations (10) and (11). The results are shown in Fig. 19.

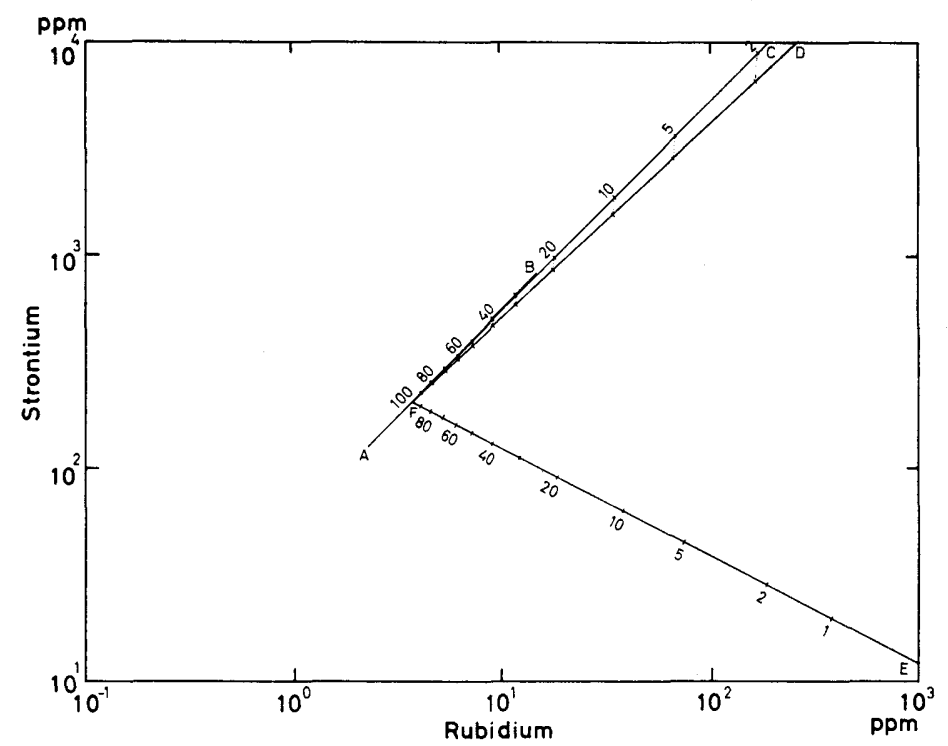

Fig. 19. Variation trends of composition of a residual liquid caused by the fractional crystallization of 60 percent melt of OFB. The point $\mathrm{A}$ is the mean composition of OFB. $F$ is the composition of 60 percent melt of OFB. Lines FC, FD and FE are trends traced by the residual liquid, when each mineral of garnet, clinopyroxene and plagioclase is respectively crystallized from the liquid. The line $A B$ is the same as that of Fig. 18. 
The trend of variation of both concentrations caused by the fractional crystallization of each mineral of garnet and clinopyroxene is respectively shown as straight lines FC and FD in Fig. 19. A number on these two lines indicates the proportion of the residual liquid fraction to the amount of the initial liquid. Since the composition of the residual liquid depends on a mineralogical constitution of the crystallizing material, the possible range of both concentrations in the residual liquid is limited in the narrow area bounded by a pair of lines FC and FD in Fig. 19.

\section{(3) The implication of the results as for the origin of the contintal crust}

Now it is well noted that $\mathrm{Rb}$ and $\mathrm{Sr}$ in the liquid both increase simultaneously with the decrease of a melting proportion of OFB or with the advance of the fractional crystallization under high pressure conditions. Therefore the $\mathrm{Rb} / \mathrm{Sr}$ ratio of the liquid is not increased significantly from the level of OFB through each of these magmatic processes or through the combination of both. Accordingly, it cannot be assumed that the continental crust, which has the $\mathrm{Rb} / \mathrm{Sr}$ ratio of about fifteen times as large as that of OFB, has been formed from OFB under high pressure conditions. This discordance may imply the operation of an additional magmatic process on the formation of the crust. Under the physical conditions of this magmatic process plagioclase should have been a stable liquidus phase in basaltic or andesitic compositions, because plagioclase is one and the only mineral to incrase a $\mathrm{Rb} / \mathrm{Sr}$ ratio of the residual liquid.

\section{(4) The flow in the upper mantle beneath the island arc}

In OFB Sr contents gather closely around their mean concentration than $\mathrm{Rb}$ contents do (Fig. 10). As it is well known, the variation trend of the $\mathrm{Sr}$ concentration in a magma changes reversely with the conversion of physical conditions from high to low pressures, under which the magmatic differentiation proceeds. Therefore the $\mathrm{Sr}$ content in igneous rocks is one of usefull indicator of the extent and physical conditions of the magmatic differentiation.

The comparison of $\mathrm{Sr}$ and $\mathrm{Rb}$ contents in the andesites of low $\mathrm{Sr}(87 / 86)$ ratios (Figs. 10 and 11) with the variation range of the calculated concentrations of both elements make us to conclude that the melting proportion can attain an extent of about 80 percent of OFB.

The occurrence of the andesites with low $\operatorname{Sr}(87 / 86)$ ratios is diminished markedly as the $\mathrm{Sr}$ concentration exceeds about $1000 \mathrm{ppm}$. And most of the andesites are massed in the range of $130 \mathrm{ppm}$ and $840 \mathrm{ppm}$ of Sr. This may indicate the limit of the extent of the fractional crystallization and that of the partial melting of OFB. 
If no enrichment of $\mathrm{Sr}$ caused by the eclogite-controlled fractionation occurred during the ascent of these andesites from the depth of the mantle to the earth's surface, the melting proportion could hardly fall to 20 percent of OFB, because the andesites of $300-500 \mathrm{ppm}$ of $\mathrm{Sr}$ are most abundant and these $\mathrm{Sr}$ contents correspond to about 40-20 percent melt of OFB. When we consider the effect of the fractional crystallization, a much larger value may be reckoned as the melting proportion of OFB. In connection with this, it should be noted that the 80 percent melting proportion would be sufficient to explain all of the now available $\mathrm{Sr}$ contents in the andesites with low $\mathrm{Sr}(87 / 86)$ ratios. The andesites of low $\mathrm{Sr}$ contents with $\mathrm{a} \mathrm{Rb} / \mathrm{Sr}$ ratio as low as that of $\mathrm{OFB}$ are not considered to be modified significantly by the fractional crystallization following to the partial melting of OFB under high pressure conditions, while the andesites of high $\mathrm{Sr}$ contents or of high $\mathrm{Rb} / \mathrm{Sr}$ ratios may be modified to some extent by the fractional crystallization during the ascent through the mantle and the crust. Although a precise value could hardly be estimated at present, the melting proportion would attain approximately 60-50 percent of OFB.

A sinking rate of the oceanic plate at a certain position along the island arc and a rate of the increase of temperature of OFB with the increase of depth in the mantle may be stationary for a definite period of the subduction. Then it may be reasonable to assume that the melting of OFB in the depth of the mantle may be at the steady state, that is, the melting proportion may be constant for a definite period. The lost of OFB by the partial melting may be compensated by the supply of OFB from the oceanic ridge. The amount of the derivative material so formed from OFB could substitute neary all of the upper mantle material above the seismic zone to the depth of about $100 \mathrm{~km}$ for about $100 \mathrm{~m} . \mathrm{y}$., if the sinking rate is assumed to be about $6.5 \mathrm{~cm} /$ year and to be constant for about 100 m.y. This speed is the mean sinking rate for the active island arcs and corresponding young orogenic belts (LE PICHON, 1968).

Accumulation of this large amount of the derivative material, however, could not explain the observed seismic properties of the upper mantle beneath the island arc. Therefore a majority of this enormous amount of the derivative material should have been continuously transported a way from the upper mantle. Thus the difficulty of explaining the seismic properties of the upper mantle may be eliminated by the introduction of a flow in the upper mantle driven by the ascent of the enormous amount of the derivative material.

Almost all of the Quarternary volcanic rocks in Northeast Japan occur in the area of $200 \mathrm{~km}$ in width from the volcanic front to the Japan Sea side (Sugimura et al, 1967). In this area, the amount of volcanic rocks decreases exponentially with the increase of the distance from the volcanic front. This variation in volume of the volcanic rocks may depend on the distribution of melts 
beneath the island arc. It may be reasonable to presume the distribution of the melts under the island arc in accordance with the distribution of the volcanic rocks on the earth's surface.

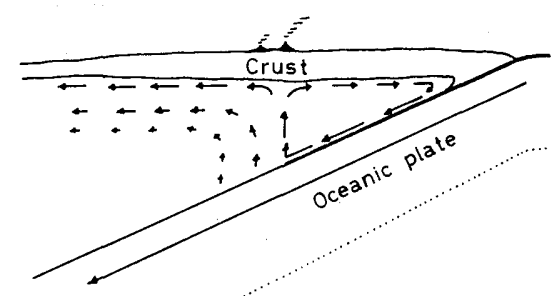

Fig. 20. A schematic cross section of an island arc illustrating a hypothetical flow in the upper mantle

A schematic mode of the flow in the upper mantle may be illustrated by a model of Fig. 20. The derivative material originated from the partial melting of OFB at the depth of about $100 \mathrm{~km}$ begins to move upward because of its low density, drives the surrounding upper mantle material to move into the same direction, reaches the bottom of the crust and then diverge into two branches turning its moving direction horizontally. One of the branches goes forward to the outer part of the island arc, reaches a point below the trench and finally is warped down by the sinking oceanic plate. The other branch continues to go toward the inner sea. The position of the volcanic front may correpond to the outer limit of the high flow velocity area in the upper mantle. The vertical flow velocity in the mantle is diminished steeply toward the outer part of the island arc, while the velocity decreases rather gently from the point below the volcanic front in the mantle toward the inner side of the island arc.

This model has some merits in explaining certain important geophysical features of the island arc. The high heat flow in the inner part of the volcanic front (UEDA and HoraI, 1964; VAquier et al., 1966) may possibly result from the ascent of the heated upper mantle and derivative materials originated in the depth of the mantle. The divergent movement of the uppermost mantle material under the volcanic front may cause horizontally oriented stresses in the overlying crust. This may explain the remarkably abundant occurrence of shallow earthquakes with horizontally oriented axes of stress (Ueda and Sugimura, 1970; Aкі, 1966). In addition, this model of the secondary mantle current beneath the island arc provides a favourable condition for the formation of the continental crust as discussed in the later section of this paper.

\section{Possible Schemes of Magmatic Process for the Formation of the Continental Crust}

\section{(1) Introduction of model mineralogical constitutions}

Before proceeding with the study of the variation trends of $\mathrm{Rb}$ and $\mathrm{Sr}$ concentrations caused by low pressure magmatic differentiations, we should have a 
knowledge on a mineral composition of the material crystallizing at low pressures.

Here is introduced a model chemical composition of the high pressure derivatives from $\mathrm{OFB}$, considering the difference in magnitude of each partition coefficient of $\mathrm{Rb}$ and $\mathrm{Sr}$ among minerals. Minerals stable as the liquidus phase at low pressures are much various than at high pressures. These minerals are olivine, ortho- and clino-pyroxenes, hornblende, plagioclase and spinel (GreEN and Ringwood, 1967 and 1968; Green, 1972). Among these minerals, clinopyroxene, hornblende and plagioclase have much larger partition coefficients of $\mathrm{Rb}$ and $\mathrm{Sr}$ as shown in Table 7.

Since the bulk partition coefficient depends on the an abundance of and the partition coefficient for each mineral in the crystallizing material, a trend of variation of $\mathrm{Rb}$ and $\mathrm{Sr}$ concentrations depends largely on the abundance of minerals with a high partition coefficient. Therefore the variation trends of $\mathrm{Rb}$ and $\mathrm{Sr}$ concentrations are approximately estimated by the consideration of only three minerals of clinopyroxene, hornblende and plagioclase. These minerals are much abundant in basaltic andesites and andesites. The intensional consideration of other minerals would purpusely make the problem complex and make us fail to

Table 8. Average chemical compositions of volconic rocks and their model mineral constitutions for dry and wet conditions

\begin{tabular}{|c|c|c|c|c|}
\hline & a & $b$ & $c$ & a \\
\hline $\mathrm{S}_{10}$ & 53.09 & 58.98 & 53.81 & 55.55 \\
\hline $\mathrm{Al}_{2} \mathrm{O}_{3}$ & 15.44 & 14.96 & 17.79 & 17.24 \\
\hline $\mathrm{Fe}_{2} \mathrm{O}_{3}$ & 4.02 & 3.29 & 2.44 & 2.30 \\
\hline $\mathrm{FeO}$ & 9.01 & 7.59 & 6.60 & 7.20 \\
\hline MgO & 4.66 & 2.74 & 5.87 & 4.42 \\
\hline $\mathrm{CaO}$ & 9.68 & 7.30 & 8.79 & 8.40 \\
\hline $\mathrm{Na}_{2} \mathrm{O}$ & 2.12 & 3.03 & 2.76 & 2.29 \\
\hline $\mathrm{K}_{2} \mathrm{O}$ & 0.45 & 0.69 & 0.62 & 0.68 \\
\hline $\mathrm{THO}_{2}$ & 1.17 & 1.06 & 0.95 & 0.83 \\
\hline $\mathrm{P}_{2} \mathrm{O}_{5}$ & 0.12 & 0.15 & 0.19 & 0.13 \\
\hline MnO & 0.23 & 0.19 & 0.19 & 0.18 \\
\hline Total & 99.99 & 99.98 & 100.01 & 99.85 \\
\hline \multicolumn{5}{|c|}{ Normative mineral assemblage for dry conditions } \\
\hline Q & 9.80 & 17.09 & 6.02 & 8.89 \\
\hline pl & 51.89 & 54.90 & 61.29 & 60.03 \\
\hline $\operatorname{cpx}$ & 29.99 & 20.08 & 26.93 & 25.03 \\
\hline others & $8 \cdot 32$ & 7.13 & 5.76 & 5.35 \\
\hline \multicolumn{5}{|c|}{ Mineral assemblage for hydrous conditions } \\
\hline Q & 9.29 & 17.03 & 7.92 & 10.15 \\
\hline $\mathrm{pl}$ & 40.62 & 45.32 & 35.45 & 40.90 \\
\hline hor & 42.66 & 31.18 & 51.99 & 44.55 \\
\hline others & 7.43 & 6.47 & 4.64 & 4.40 \\
\hline
\end{tabular}

Data are Kuno's average compositions of aphyric rocks from the Izu-Hakone region. a: basalt-andesite, $b$ : andesite, $c$ : basalt-andesite $d$ : andesite. a and $b$ are of the pigeonitic rock series. $c$ and $d$ are of the hypersthenic series. pl. includes the orthoclase component. 
see the essential.

Therefore, in this case, the necessary condition is to estimate a rough chemical composition or to limit the range of possible chemical compositions. Accordingly Kuno's average chemical compositions of aphyric basaltic andesites and andesites of both hyperthenic and pigeonitic rock series from the Izu-Hakone region (Kuno, 1968) are adopted here (Table 8) as the model chemical compositions of the high pressure derivatives from $\mathrm{OFB}$ ascending from the seismic zone. The selection of these chemical compositions depends on low $\operatorname{Sr}(87 / 86)$ ratios of the volcanic rocks from this region. The assignment of the derivative material to be basaltic andesite and/or andesite depends on the conclusion of GREEN and RINGwood (1968).

The estimation of abundances of minerals follows the ordinary way of calculation of normative minerals. Although the pressure dependent variation of these mineral abundances may be important in this case, this variation is ignored for the time being, because the introduction of this variation makes the discussion too complex.

The calculation of the mineral composition for hydrous conditions is made in the following way. At first, actinolite is produced from normative wollastonite, enstatite and ferrosilite until the wollastonite is exhausted. Then tchermackite is made from enstatite, ferrosilite and anorthite until the pyroxene components are used up. The final mineral assemblage is plagioclase, hornblende, quartz and ilmenomagnetite. Therefore the bulk partition coefficients depend largely on the proportion of plagioclase to hornblende.

Sr contents in the high pressure derivatives have been already limited to be from 130 to $840 \mathrm{ppm}$. For $\mathrm{Rb}$ contents, the $\mathrm{Rb} / \mathrm{Sr}$ ratio of the high pressure derivatives may be assumed to be 0.0177 , which is the mean of those of OFB, since the $\mathrm{Rb} / \mathrm{Sr}$ ratio of the derivative melt from OFB is found not to be increased by the high pressure partial melting or also the high pressure fractional crystallization. This hypothetical range of $\mathrm{Rb}$ and $\mathrm{Sr}$ concentrations is referred to as the simplified composition of the high pressure derivatives in the later sections. The difference of the $\mathrm{Rb} / \mathrm{Sr}$ ratio between the calculated and this hypothetical one, which becomes significant with the increase of $\mathrm{Sr}$ content in the high pressure derivatives (Figs. 18 and 19 ), is referred to as the residual $\mathrm{Rb} / \mathrm{Sr}$ ratio.

\section{(2) The low pressure fractional crystallization}

Calculated variation trends of both $\mathrm{Rb}$ and $\mathrm{Sr}$ concentrations under low pressure dry conditions is shown in Fig. 21. The line AB in Fig. 21 represents the simplified composition of the high pressure derivative melts. The line AD represents the variation of both $\mathrm{Rb}$ and $\mathrm{Sr}$ concentrations in the residual melt, when the mineral composition of the material crystallizing from the liquid is assumed to be that of the model composition (a) in Table 8 and the partition coefficients of $\mathrm{Rb}$ and $\mathrm{Sr}$ are assumed to be 0.0152 and 1.49 respectively. The partition 


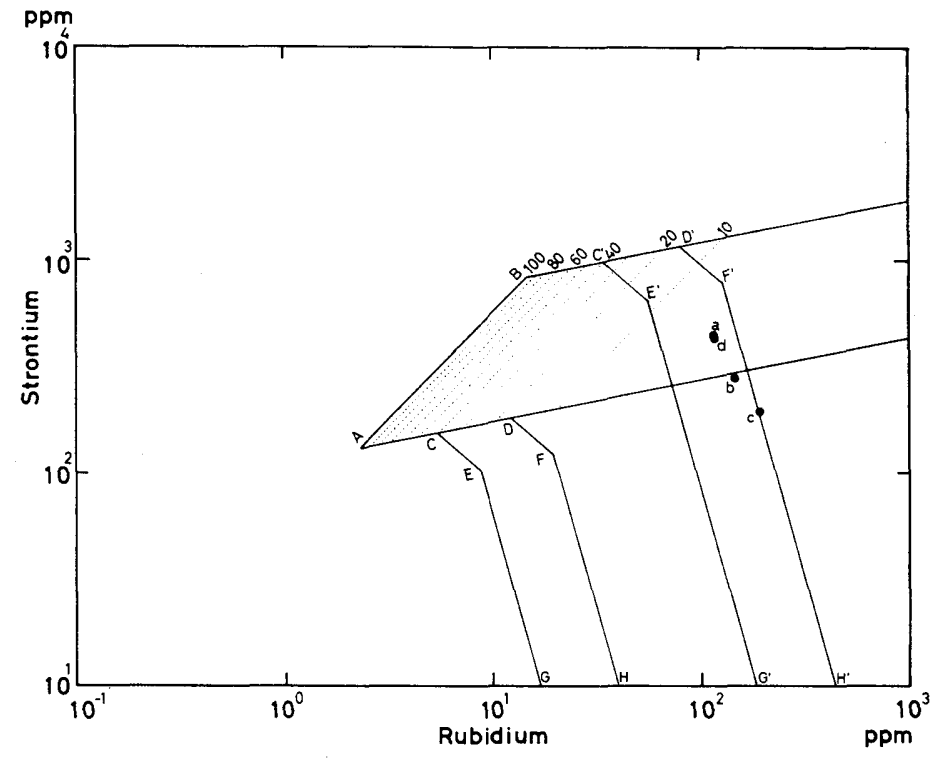

Fig. 21. Variation trends of $\mathrm{Rb}$ and $\mathrm{Sr}$ concentrations in the residual liquid produced by the low pressure fractional crystallization from the high pressure derivative melts. The line $A B$ is the simplified composition of the high pressure derivative melts. Lines $\mathrm{AD}$ and $\mathrm{BD}^{\prime}$, and their extensions are the variation trends traced by the residual liquid, when a material with the dry mineral assemblage of the model composition (a) in Table 8 is continued to be crystallized from the original melt of composition $A$ and $B$ respectively. Dotted lines represent compositions of the residual liquid after every 10 percent crystallization from the original melt of the composition $\mathrm{AB}$. When the variation of strontium partition coefficient caused by the change of composition of plagioclase is evaluated, these variation trends become sloped steeply toward the lower right hand side as expressed by lines CEG $\left(\mathrm{C}^{\prime} \mathrm{E}^{\prime} \mathrm{G}^{\prime}\right)$ and $\mathrm{DFH}\left(\mathrm{D}^{\prime} \mathrm{F}^{\prime} \mathrm{H}^{\prime}\right)$. Points a and $\mathbf{d}$ are the mean composition of the continental crust reported by AHRENs and $\mathbf{T}_{A Y L O R}$ (1961) and HURLeY et al. (1962) respectively. Points $\mathbf{b}$ and $\mathbf{c}$ are mean compositions of granites reported by $T_{\text {AYLOR }}$ (1961) and HurLeY et al. (1962) respectively.

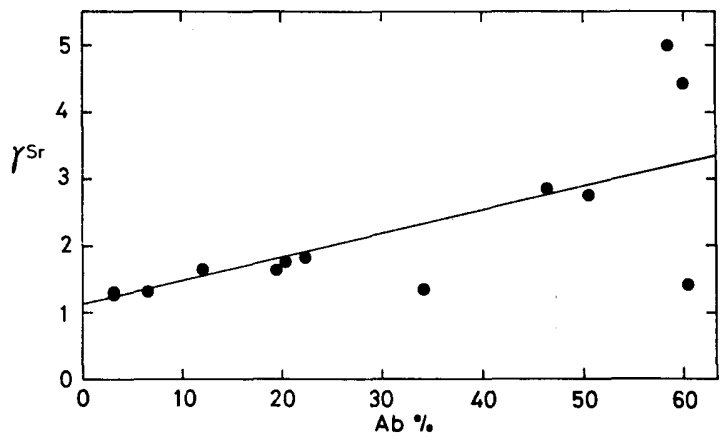

Fig. 22. The dependence of strontium partition coefficient on the composition of plagioclase. 
coefficient of Sr for plagioclase, however, changes remarkably in accordance with the albite content in plagioclase as shown in Fig. 22. Therefore the partition coefficient may change with the advance of the fractional crystallization.

For a rough approximation, bulk partition coefficients of both elements are assumed to be constant until the albite content in plagioclase becomes 50 percent. This composition may be attained, when the residual melt fraction becomes about 40 or 17 percent, depending on the composition of the original melt. Therefore the slope of the lines $\mathrm{CE}$ and $\mathrm{DF}$, which start from two points on the line $\mathrm{AD}$ corresponding 40 and 17 percent of the residual melt fraction respectively, is determined using the estimates of both partition coefficients corresponding to 50 percent albite content in plagioclase. Then the plagioclase becomes gradually rich in albite. The slope of the two lines starting from the points $\mathrm{E}$ and $\mathrm{F}$ are calculated from the data of alkali-feldspar. Continuous variations of mineral composition of the material crystallizing and also that of partition coefficients of both elements for plagioclase with the advance of crystallization should be considered for the accurate determination of the variation trends of the residual melt.

As the original composition changes from $A$ to $B$ in Fig. 21, we get an analogous pair of lines $\mathrm{BC}^{\prime} \mathrm{E}^{\prime} \mathrm{G}^{\prime}$ and $\mathrm{BD}^{\prime} \mathrm{F}^{\prime} \mathrm{H}^{\prime}$. Then the composition of the residual liquid by the fractional crystallization from the high pressure derivative melts from OFB should be in the field GECABD'F' $\mathrm{H}^{\prime}$ in Fig. 21.

The coincidence of the variation range of volcanic rocks of andesite, dacite

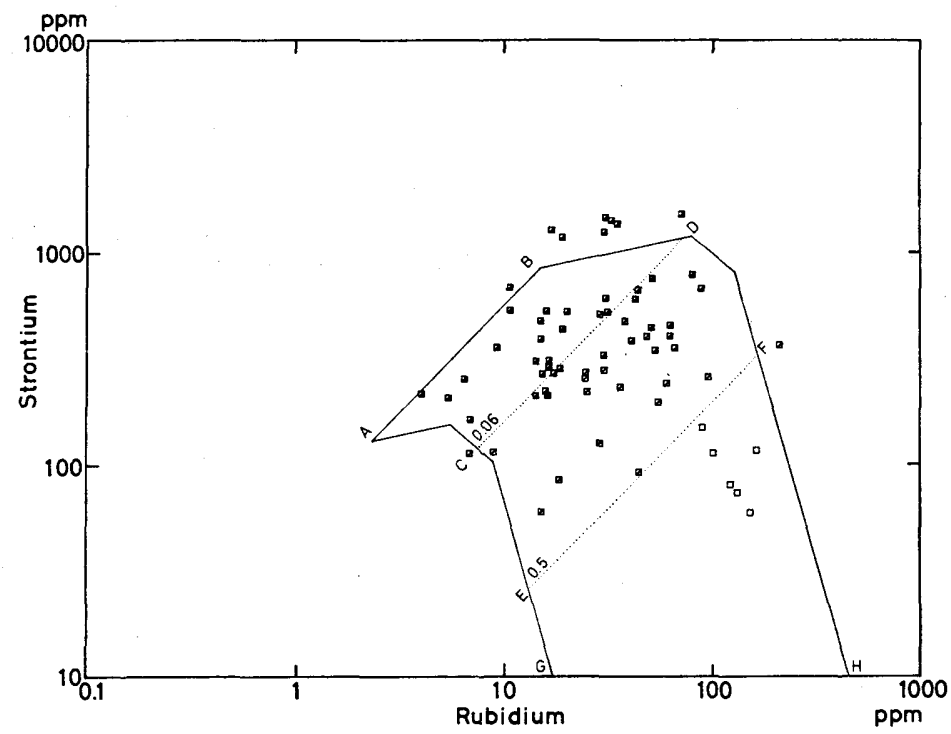

Fig. 23. The comparison between the calculated range of the composition of the residual liquid and compositions of various volcanic rocks with low $\mathrm{Sr}(87 / 86)$ ratios. Marks are the same as those of Fig. 10. Two lines CD and EF of the constant $\mathrm{Rb} / \mathrm{Sr}$ ratios of 0.06 and 0.5 respectively limit the range of dacites. Other lines and points are the same as those of Fig. 21. 
and rhyolite of low $\mathrm{Sr}(87 / 86)$ ratios with the calculated range of both $\mathrm{Rb}$ and $\mathrm{Sr}$ concentrations (Fig. 23) is so excellent that it is possible to regard of these volcanic rocks as the products of the fractional crystallization. The variation range of dacites is bounded by a pair of constant $\mathrm{Rb} / \mathrm{Sr}$ ratio lines $\mathrm{CD}$ and $\mathrm{EF}$ in Fig. 23. Therefore the change of the major element composition during the fractional crystallization seems to be proceeding almost independently of the original concentrations of $\mathrm{Rb}$ and $\mathrm{Sr}$.

Through the fractional crystallization, a material with a high $\mathrm{Rb} / \mathrm{Sr}$ ratio, which is comparable to those of the continental crust and granites, can be produced from the high pressure derivative melts. Both $\mathrm{Rb}$ and $\mathrm{Sr}$ contents in the material, however, are generally lower than those in the continental crust and the granites. If the sialic crust was assumed to be produced by the fractional crystallization, the major chemical composition of the continental crust should be dacitic, because the $\mathrm{Rb} / \mathrm{Sr}$ ratio of the continental crust is about 0.27 (Fig. 23). This is opposed to the previous conclusion that the major chemical composition of the lower crust should be andesitic and could not exceed dacite toward the acid side, and also opposed to the andesitic model of the crust (TAYLOR, 1968). The dacitic model of the crust cannot sufficiently explain the mean composition of the continental crust.

Accordingly, the comparison of the variation range of $\mathrm{Rb}$ and $\mathrm{Sr}$ concentrations with the mean compositions of the continental crust, $\mathbf{a}$ and $\mathbf{d}$ in Fig. 21, and that of granites, $\mathbf{b}$ and $\mathbf{c}$ in Fig. 21, convince us of the difficulty of formation of these crustal material from the high pressure derivative melts through the fractional crystallization under low pressure conditions. Variation trends result from the low pressure fractional crystallization under hydrous conditions are almost the same as the above.

Therefore these comparisons make us to conclude that the low pressure fractional crystallization could not be regarded as the essential magmatic process for the formation of the continental crust.

\section{(3) The role of the low pressure equilibrium partial melting in the formation of the continental crust}

Since the high pressure derivative melt from OFB may be differentiated to some extent by the eclogite-controlled fractional crystallization during the ascent from the seismic zone at about $100 \mathrm{~km}$ depth in the mantle, the solidus temperature of the residual liquid may be decreased with the advance of the fractional crystallization. The solidus temperature, however, is the lowest among those of various volcanic rocks at pressures over $13 \mathrm{~kb}$ under dry conditions (Green and RINGwOoD, 1968), then the residual liquid could not change its chemical composition exceeding a point which corresponds to the andesite. 


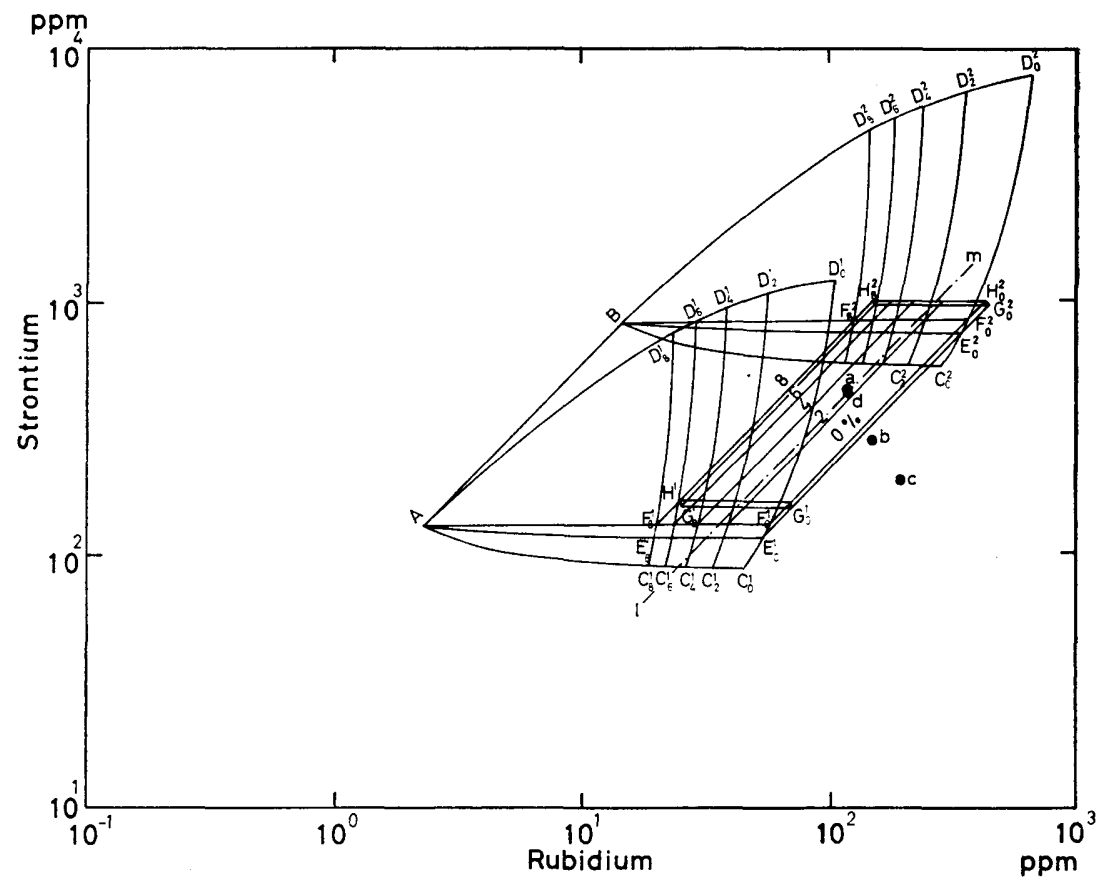

Fig. 24. Compositions of the liquid produced by the equilibrium partial melting from the high pressure derivatives. The line $A B$ is the simplified composition of the high pressure derivatives. Capital letters besides $A$ and $B$ denote mineralogical constitutions of the residuum, C: $100 \%$ plagioclase, D: $100 \%$ clinopyroxene, E: $26.8 \%$ clinopyroxene and $73.2 \%$ plagioclase, F: $36.6 \%$ clinopyroxene and $63.4 \%$ plagioclase, $\mathrm{G}$ : the dry mineral assemblage of the model composition (b) of Table 8, and $\mathrm{H}$ : the dry mineral assemblage of the model composition (a) of Table 8 . Numbers $0,2,4,6$ and 8 written at the foot of each letter denote $0.2,4,6$ and $8 \%$ melt of the high pressure derivative. Numbers 1 and 2 written at the shoulder of each letter denote the composition of the source materials $A$ and $B$ respectively. A line $1 \mathrm{~m}$ represents the mean $\mathrm{Rb} / \mathrm{Sr}$ ratio of the continental crust. Points $\mathbf{a}, \mathbf{b}, \mathbf{c}$, and $\mathbf{d}$ are the same as those in Fig. 21.

Since the solidus temperature of the dry andesite intersects the oceanic geothermal temperature distribution at depth of about $90 \mathrm{~km}$, most of the derivative material from OFB may ascent in a solid state from the depth of about $90 \mathrm{~km}$ in the mantle, while some of the derivative material ascending in the high velocity region of the mantle may rise adiabatically and may reach the bottom of the crust in a state of melt. In connection with these circumstances, it should be noticed that the shear wave velocity of the upper mantle at depth between 30 and $80 \mathrm{~km}$ under the Japanese Islands is lower than those under the continental and oceanic regions (KANAMORI, 1971). This may be well explained by the assumption of the incipient melting of a material between these depths.

In the scheme of the mantle current under the island arc, if the high pressure derivative rises through the upper mantle and then melts partially under the base 
of the crust, or the derivative rises in a incipiently melted state, and then the liquid fraction is squeezed out and added to the base of the crust, and the residuum is transported toward both sides of the island arc, the low pressure equilibrium partial melting seems to be a possible process for the formation of the continental crust.

The variation range of $\mathrm{Rb}$ and $\mathrm{Sr}$ concentrations in the liquid fraction produced by the low pressure equilibrium partial melting from the high pressure derivatives of the simplified composition is shown in Fig. 24. The line AB in Fig. 24 represents the simplified composition of the high pressure derivatives ascending from the seismic zone. Lines $\mathrm{D}_{0}^{1} \mathrm{~A}$ and $\mathrm{C}_{0}^{1} \mathrm{~A}$ are the trend of variation of $\mathrm{Rb}$ and $\mathrm{Sr}$ concentrations which are traced by the liquid fraction with the advance of the equilibrium partial melting of a material of the composition $A$, when the residuum is assumed to be composed only of clinopyroxene or plagioclase respectively. $\mathrm{C}_{0}^{1}, \mathrm{C}_{2}^{1}, \mathrm{C}_{4}^{1}, \mathrm{C}_{6}^{1}$ and $\mathrm{C}_{8}^{1}$ on the line $\mathrm{C}_{0}^{1} \mathrm{~A}$, and $\mathrm{D}_{0}^{1}, \mathrm{D}_{2}^{1}, \mathrm{D}_{4}^{1}, \mathrm{D}_{8}^{1}$ and $\mathrm{D}_{8}^{1}$ on the line $\mathrm{D}_{0}^{1} \mathrm{~A}$ represent the composition of the liquid, when the melting proportion is $0,2,4,6$ and 8 percent respectively. Lines $\mathrm{E}_{0}^{1} \mathrm{~A}$ and $\mathrm{F}_{0}^{1} \mathrm{~A}$ are the variation trend of $\mathrm{Rb}$ and $\mathrm{Sr}$ concentrations in the liquid, when the residuum is assumed to be composed of plagioclase and clinopyroxene, and the proportion of plagioclase to clinopyroxene is assumed to be equivalent to that of the model composition (b) and (a) in Table 8 respectively.

When the composition of the melting material changes along the line $A B$ from $\mathrm{A}$ to $\mathrm{B}$, then the composition of the liquid of a definite melting proportion moves parallel to the line $\mathrm{AB}$ toward the upper right side of the diagram. Therefore a suite of lines $\mathrm{F}_{0}^{1} \mathrm{~F}_{0}^{2}, \mathrm{~F}_{2}^{1} \mathrm{~F}_{2}^{2}, \mathrm{~F}_{4}^{1} \mathrm{~F}_{4}^{2}, \mathrm{~F}_{6}^{1} \mathrm{~F}_{6}^{2}$ and $\mathrm{F}_{8}^{1} \mathrm{~F}_{8}^{2}$ represents the range of the composition of the liquid of the various melting proportions of $0,2,4,6$ and 8 percent respectively, where the proportion of plagioclase to clinopyroxene in the residuum is supposed to be that of the model composition (a). Another suite of lines $\mathrm{E}_{0}^{1} \mathrm{E}_{0}^{2}, \mathrm{E}_{2}^{1} \mathrm{E}_{2}^{2}, \mathrm{E}_{4}^{1} \mathrm{E}_{4}^{2}, \mathrm{E}_{6}^{1} \mathrm{E}_{6}^{2}$ and $\mathrm{E}_{8}^{1} \mathrm{E}_{8}^{2}$ may be given for the model composition (b).

When the occurrence of the minerals like quartz and magnetite in the residuum is taken into account, the range of the composition of the liquid slightly moves parallel to the line $A B$ toward the upper right side of the diagram as shown in Fig. 24, that is, the trends $\mathrm{E}_{0}^{1} \mathrm{E}_{8}^{1}\left(\mathrm{E}_{0}^{2} \mathrm{E}_{8}^{2}\right)$ and $\mathrm{F}_{0}^{1} \mathrm{~F}_{8}^{1}\left(\mathrm{~F}_{0}^{2} \mathrm{~F}_{8}^{2}\right)$ becomes the range $\mathrm{G}_{0}^{1} \mathrm{G}_{8}^{1}$ $\left(\mathrm{G}_{0}^{2} \mathrm{G}_{8}^{2}\right)$ and $\mathrm{H}_{0}^{1} \mathrm{H}_{8}^{1}\left(\mathrm{H}_{0}^{2} \mathrm{H}_{8}^{2}\right)$ respectively. Along with these variation ranges, the mean compositions of the continental crust, $\mathbf{a}$ and $\mathbf{d}$, and of granites, $\mathbf{b}$ and $\mathbf{c}$ are plotted in Fig. 24.

The coincidence of the mean composition of the continental crust is so excellent that the partial melting can be regarded to be a possible process through which the continental crust is produced from the high pressure derivatives. The separation of the two mean compositions of granites far from the range of the composition attained through the partial melting of the high pressure derivatives 
implys that most of the granites could not produced through this process. It should be noticed that the product of the partial melting have a constant $\mathrm{Rb} / \mathrm{Sr}$ ratio close to the mean crustal abundance ratio of both elements. Its $\mathrm{Rb} / \mathrm{Sr}$ ratio is independent of its position in the island arc and also of an age of its formation, when the melting proportion at which the liquid is effectively separated from the residdum is constant.

\section{(4) The role of zone melting in the formation of the continental crust}

i) The convergent concentrations of rubidium and strondium

Now it is found that both of the fractional crystallization and the partial melting, regardless of their importance for the formation of the continental crust, are a possible magmatic process operative near the base of the crust. Therefore the existence of a material with a much lower solidus temperature, which is produced through either of these magmatic processes, may be expected at the top of the mantle or at the base of the crust. In addition to this, water primarily contained in OFB in a small quantity (Mryashiro, 1973) may be transfered to the high pressure derivatives from OFB, then transported to the base of the crust and finally enriched in this material. The enrichment of water may remarkably depress the solidus temperature of this material.

When this low soidus temperature material meets the successive series of the heated high pressure derivatives ascending from the seismic zone, they may be melted partially and then mixed each other. The residuum, gravitationary separated from the melt, may be transported toward mostly inner and partly outer side of the island arc by the mantle current. The melt left beheind may meet, and then melt again and be mixed with the successive series of the high pressure derivatives. The residuum so formed may be transported again. Therefore this type of magmatic process may continue as long as OFB is supplied from the oceanic ridge. This scheme of the magmatic differentiation seems to be analogous to the zone refining processing of the semi-conductive material.

In connection with the operation of this scheme of the magmatic process, it is very interestesting that the discrepancy between the earth's models resulted from Rayleigh and Love waves data is well explained by the assumption of the magma pockets of a flat ellipisoidal shape in the upper mantle beneath the island arc (TAKEuchi et al., 1968).

When an amount of the liquid is held constant, the variation of $\mathrm{Rb}$ and $\mathrm{Sr}$ concentrations in the liquid zone follows the equations (16) and (18). The results of the calculation for the low pressure dry and wet condittons are shown in Fig. 25. The line $\mathrm{AB}$ in Fig. 25 represents the simplified composition of the high pressure derivatives from $\mathrm{OFB}$ and is the initial conditions for the calculation.

When one of minerals of clinopyroxene, hornblende and plagioclaseis, as a 
simple case, continued to be crystallized with the proceeding of the zone melting of the high pressure derivatives of the composition $A$, concentrations of $R b$ and $\mathrm{Sr}$ in the liquid zone may trance the lines $\mathrm{AD}^{1}, \mathrm{AE}^{1}$ and $\mathrm{AC}^{1}$, and may ultimately converge into the compositions $\mathrm{D}^{\mathbf{1}}, \mathrm{E}^{\mathbf{1}}$ and $\mathrm{C}^{\mathbf{1}}$ in Fig. 25 respectively.

Therefore, if the liquid is held essentially under dry conditions, the composition of the liquid is somewhere in the field bounded by the lines $\mathrm{AC}^{1}, \mathrm{C}^{1} \mathrm{D}^{1}$ and $\mathrm{AD}^{1}$, and converge into a point somewhere on the line $\mathrm{C}^{1} \mathrm{D}^{1}$ depending on abundances of plagioclase and clinopyroxene in the material crystallizing from the liquid. Alternatively, if the liquid zone is held under water sufficient conditions, the composition of the liquid zone is somewhere in the field bounded by the lines

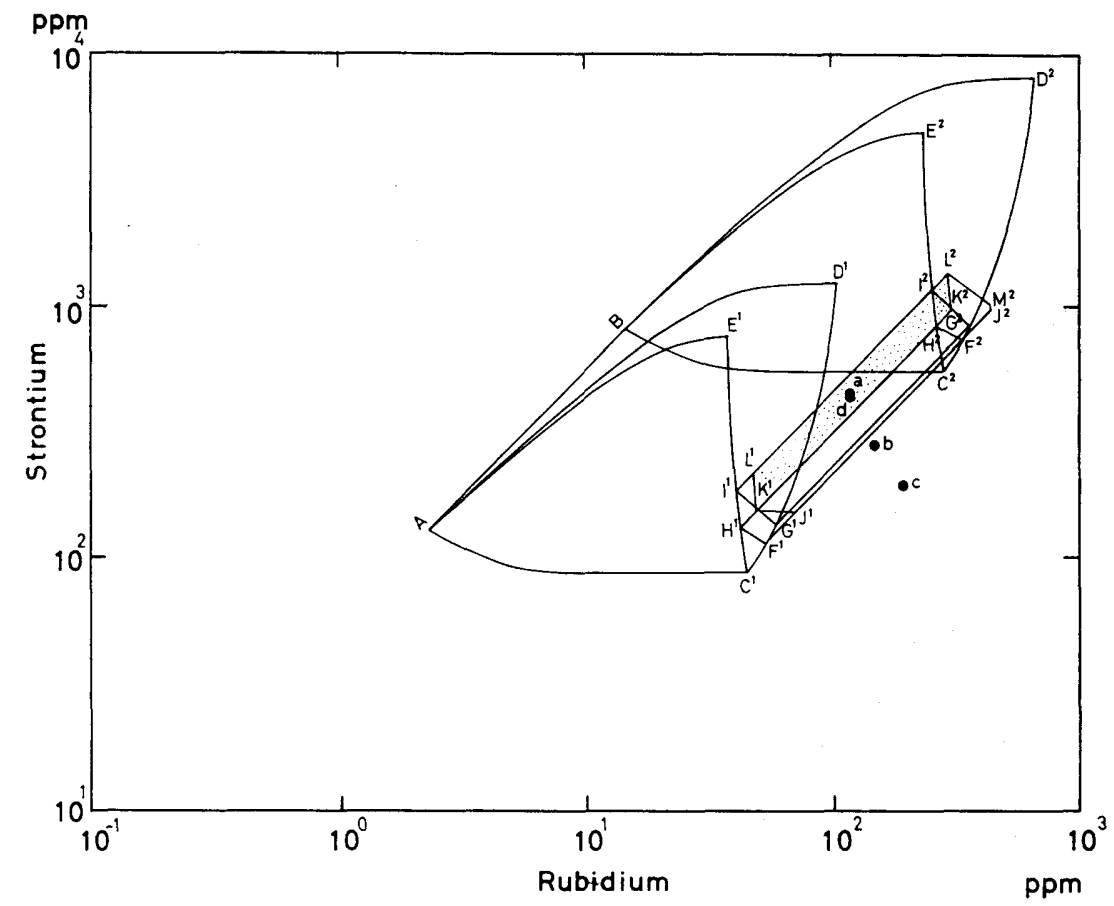

Fig. 25, Convergent concentrations of $\mathrm{Rb}$ and $\mathrm{Sr}$ in the liquid zone produced by the zone melting from the high pressure derivatives at low pressures. The line $A B$ represents the simplified composition of the high pressure derivatives from OFB. $A$ is the mean composition of OFB. Besides A and B, capital letters denote mineralogical constitution of the material crystallizing from the liquid, C: $100 \%$ plagioclase, D: $100 \%$ clinopyroxene, E: $100 \%$ hornblende, F : $73.2 \%$ plagioclase and $26.8 \%$ clinopyroxene, G: $63.4 \%$ plagioclase and $36.6 \%$ clinopyroxene, H: $59.2 \%$ plagioclase and $40.8 \%$ hornblende, I: $40.5 \%$ plagioclase and $59.5 \%$ hornblende, J: dry mineral assemblage of the model composition (b) of Table 8, $\mathrm{K}$ : hydrous mineral assemblage of the model composition (b) of Table 8, L: hydrous mineral assemblage of the model composition (c) of Table 8, M: dry mineral assemblage of the model composition (a) of Table 8. Numbers 1 and 2 written at the shoulder of each letters denote the composition of the melting material $A$ and $B$ respectively. The dotted field shows the range of the convergent concentrations of $\mathrm{Rb}$ and $\mathrm{Sr}$ attained under water sufficient conditions. Points $\mathbf{a}, \mathbf{b}, \mathbf{c}$ and $\mathbf{d}$ are the same as those in Fig. 21. 


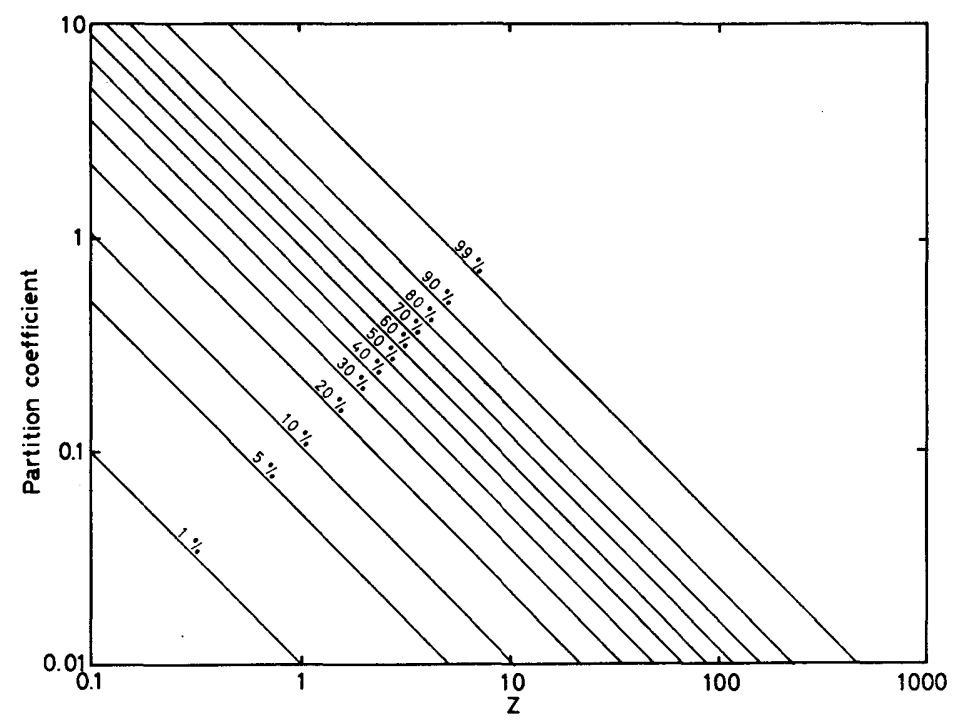

Fig. 26. The relation between a partition coefficient and a ratio of an amount already melted to an amount of the liquid. Numbers on each line represent degrees of convergence $(\alpha)$.

$\mathrm{AC}^{1}, \mathrm{C}^{1} \mathrm{E}^{1}$ and $\mathrm{AE}^{1}$, and converge into a point somewhere on the line $\mathrm{C}^{1} \mathrm{E}^{\mathbf{1}}$ depending on the abundances of plagioclase and hornblende.

A degree of the convergence of these concentrations, that is $\alpha$ in the equation (23), depends on the partition coefficient $\gamma$, and the ratio $Z$ of an amout of the liquid $\mathrm{M}_{0}$ and an amount of the high pressure derivatives already melted and crystallized $\mathrm{X}$.

When the composition of the high pressure derivatives changes along the line $\mathrm{AB}$ from $\mathrm{A}$ to $\mathrm{B}$ in Fig. 25, a set of variation trends moves parallel to the line $\mathrm{AB}$ from $\mathrm{AC}^{1}, \mathrm{AD}^{1}, \mathrm{AE}^{1}$ to $\mathrm{BC}^{2}, \mathrm{BD}^{2}$ and $\mathrm{BE}^{2}$ respectively. Then the composition of the liquid zone must be in the field $\mathrm{AC}^{1} \mathrm{C}^{2} \mathrm{D}^{2} \mathrm{~B}$, depeding on the mineralogical constitution of the crystallizing material, on the initial composition of the high pressure derivatives, on the water content in the liquid zone and also on the extent of proceeding of the zone melting.

If a sufficient amount of the high pressure derivatives is supplied, in other words, if the oceanic plate continues its downward movement at the island arc for a sufficient time, the chemical composition of the liquid zone may converge into a definite range. Then what we must consider for the zone melting is the variation range of the convergent composition of the liquid zone. In terms of $\mathrm{Rb}$ and $\mathrm{Sr}$ concentrations, that is a trace of the field $\mathrm{C}^{1} \mathrm{D}^{1} \mathrm{E}^{1}$ in Fig. 25 moved parallel to the line $A B$ from $C^{1} D^{1} E^{1}$ to $C^{2} D^{2} F^{2}$.

Partition coefficients of the major elements are generally much larger than that of $\mathrm{Rb}$ by about 10 times or more. Therefore in terms of the major chemistry, 
the liquid zone may attain a stationary state in the early stage of the proceeding of the zone melting. Under this condition, the major chemical composition of the crystallizing material is equivalent to the melting material, viz., the composition of the high pressure derivatives. Then it follows that the mineral composition of the crystallizing material approximates to those of the model compositions in Table 8 and that the major chemical composition of the liquid zone approximates to andesite or somewhat more acid one.

Since the two groups of points $a, b, c, d$ and $a^{\prime}, b^{\prime}, c^{\prime}, d^{\prime}$ in Fig. 27 represent mineral assemblages for the model compositions under dry and water sufficient conditions respectively, we can limit the range of the mineral assemblage in the material crystallizing under intermediate conditions. That is the quadrangle $a^{\prime} b^{\prime} c^{\prime}$ in Fig. 27. The variation of the convergent $\mathrm{Rb} / \mathrm{Sr}$ ratio is also shown in Fig. 27. The calculation of the convergent $\mathrm{Rb} / \mathrm{Sr}$ ratio of the liquid zone is based on the assumption that the $\mathrm{Rb} / \mathrm{Sr}$ ratio of the melting material is equivalent to the mean $\mathrm{Rb} / \mathrm{Sr}$ ratio of $\mathrm{OFB}$.

Because the bulk partition coefficients of $\mathrm{Rb}$ and $\mathrm{Sr}$ under low pressure dry and wet conditions depend mostly on these three minerals of plagioclase, clinopyroxene and hornblende, the result of the calculation gives the possible range of the convergent $\mathrm{Rb} / \mathrm{Sr}$ ratio of the liquid zone. That is from 0.22 to 0.46 .

As a matter of fact, the mineral constitution triangle of Fig. 27 is equivalent to the field $\mathrm{C}^{1} \mathrm{D}^{1} \mathrm{E}^{1}$ in Fig. 25. The range of the mineral composition, the

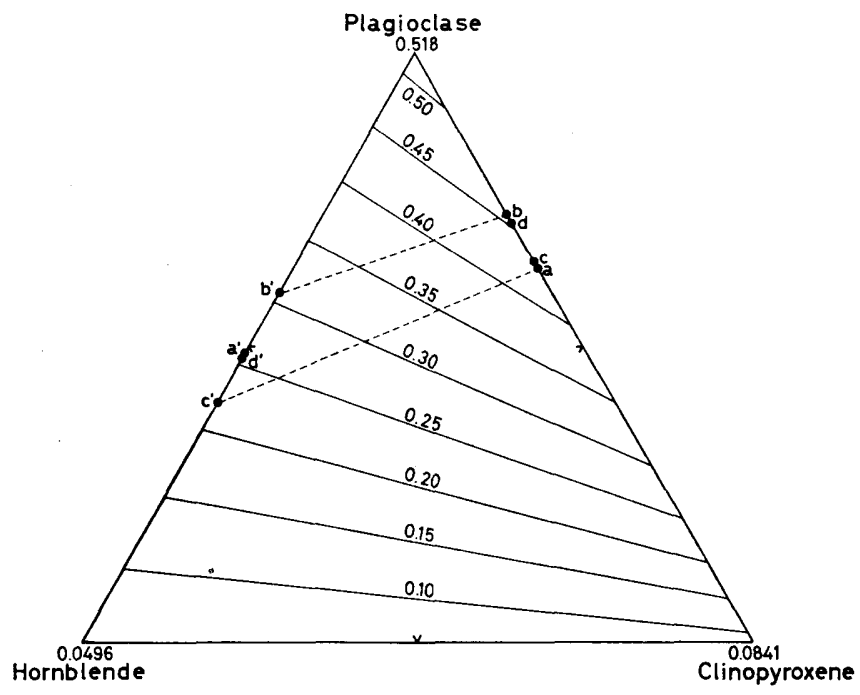

Fig. 27. The convergent $\mathrm{Rb} / \mathrm{Sr}$ ratio in the liquid zone. Points $\mathrm{a}, \mathrm{b}, \mathrm{c}$ and $\mathrm{d}$ represent mineral assemblages of the model composition $a, b, c$ and $d$ of Table 8 respectively. Points $a^{\prime}, b^{\prime}, c^{\prime}$ and $d^{\prime}$ represent their hydrous mineral assemblages respectively. The Possible mineral assemblage of the high pressure derivatives is expressed by the field $a^{\prime} b^{\prime} c^{\prime}$. 
quadrangle $a b b^{\prime} c^{\prime}$, becomes the field $\mathrm{G}^{1} \mathrm{~F}^{1} \mathrm{H}^{1} \mathrm{I}^{1}$ in Fig. 25. The possible range of the convergent $\mathrm{Rb}$ and $\mathrm{Sr}$ concentrations may be given by the trace of the field $\mathrm{G}^{1} \mathrm{~F}^{1} \mathrm{H}^{1} \mathrm{I}^{1}$ moved parallel to the line $A B$ from $\mathrm{G}^{1} \mathrm{~F}^{1} \mathrm{H}^{1} \mathrm{I}^{1}$ to $\mathrm{G}^{2} \mathrm{~F}^{2} \mathrm{H}^{2} \mathrm{I}^{2}$. That is the field $\mathrm{F}^{1} \mathrm{~F}^{2} \mathrm{G}^{2} \mathrm{I}^{2} \mathrm{H}^{1}$ in Fig. 25. This field is slightly moved parallel to the line $\mathrm{AB}$ toward the upper right hand side of Fig. 25 and becomes $\mathrm{J}^{1} \mathrm{~J}^{2} \mathrm{M}^{2} \mathrm{~L}^{2} \mathrm{~L}^{1} \mathrm{~K}^{1}$, when we evaluate the amount of quartz and ilmeno-magnetite in the crystallizing material.

The mean crustal abundance of $\mathrm{Rb}$ and that of $\mathrm{Sr}$, $\mathbf{a}$ and $\mathbf{d}$ in Fig. 25, lie in this field of the convergent concentrations of both elements, especially at the center of the dotted field $\mathrm{K}^{1} \mathrm{~K}^{2} \mathrm{~L}^{2} \mathrm{~L}^{1}$, which emerges under water sufficient conditions. Now it turned out clear that this magmatic process of zone melting can explain sufficiently the mean abundance of both elements in the continental crust. The zone melting of the high pressure derivatives under wet or more probably water sufficient conditions at low pressures seems to a possible and important magmatic process for the formation of the continental crust.

The deviation of the convergent $\mathrm{Rb} / \mathrm{Sr}$ ratio in the liquid zone is reasonably expected to be small, since the liquid zone should meet with the enormous amount of the derivative material to attain the convergent concentrations. In other words, the liquid zone is derived from a large amount of OFB, about 100 times of the liquid zone. Then the variation of the $\mathrm{Rb} / \mathrm{Sr}$ ratio in OFB is almost completely made homogeneous by this magmatic process. Therefore there is no need for us to estimate the deviation of the convergent $\mathrm{Rb} / \mathrm{Sr}$ ratio in the liquid zone originated in the variation of the $\mathrm{Rb} / \mathrm{Sr}$ ratio in OFB. Then the ranges of the convergent concentrations of $\mathrm{Rb}$ and $\mathrm{Sr}$, too, are almost independent of the variation of these concenerations in OFB. Then it follows that the $\mathrm{Rb} / \mathrm{Sr}$ ratio of the primary crust so formed, which means that the chemistry of this material is not affected by any later magmatic differentiation, is independent of its position in the island arc and does not vary among the island arcs. If the prevailing condition for the zone melting are decided to be dry or water sufficient, the $\mathrm{Rb} / \mathrm{Sr}$ ratio of the primary crust is almost constant, because the $\mathrm{Rb} / \mathrm{Sr}$ ratio depends largely on the water content in the liquid zone. The variation range of the convergent $\mathrm{Rb} / \mathrm{Sr}$ ratio of the liquid zone is rather narrow ranging from 0.22 to 0.31 under the water sufficient conditions.

ii) The convergent concentration of potassium

Since the geochemical behaviour of $\mathrm{Rb}$ during magmatic differentiations is similar to that of $\mathrm{K}$ and depends on the concentration of $\mathrm{K}$, we must study on the variation of the $\mathrm{K}$ content in the liquid zone.

Variation trends of $\mathrm{K}$ and $\mathrm{Rb}$ concentrations in the liquid fraction produced by the equilibrium partial melting from OFB under high pressure conditions are shown in Fig. 28. The point $\mathrm{A}$ is the mean composition of OFB, 0.22 percent of $\mathrm{K}$ (CANN, 1971) and $2.29 \mathrm{ppm}$ of $\mathrm{Rb}$. 


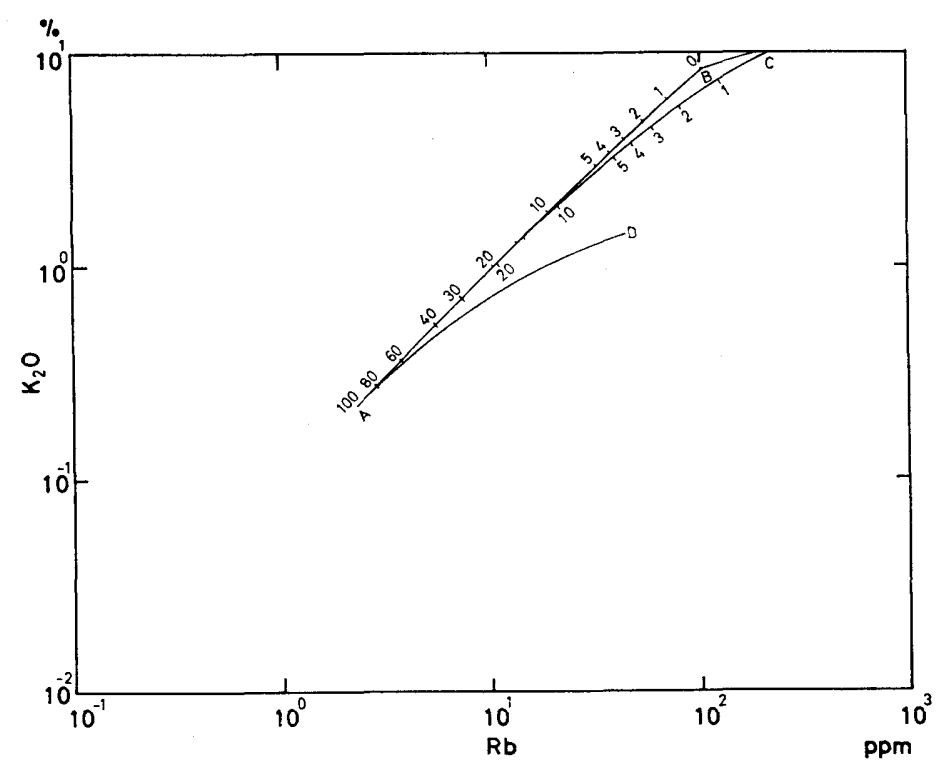

Fig. 28. Variation trends of $\mathrm{Rb}$ and $\mathrm{K}$ concentrations in a liquid produced by the equilibrium partial melting from OFB. $A$ is the mean composition of OFB. Lines $A B$ and $A C$ are variation trends traced by the liquid, when the residuum is assumed to be composed of one of minerals of garnet and clinopyroxene respectively. Numbers on these lines represent fractions of the liquid. The line $\mathrm{AD}$ is a variation trend traced by the liquid, when the residuum is assumed to be composed of plagioclase.

Partition coefficients of $\mathrm{K}$ for various minerals are listed in Table 7. The source of the data for the partition coefficients of $K$ is Griffin and Murthy (1969), Higuchi and Nagasawa (1969), Philpotts and Schnetzler (1970), Nagasawa and Schnetzler (1971) and Goodman (1972)

Lines $\mathrm{AB}, \mathrm{AC}$ and $\mathrm{AD}$ in Fig. 28 are variation trends of both concentrations in the liquid fraction, when the residuum is assumed to be composed of only one phase of the three minerals, garnet, clinopyroxene and plagioclase respectively. Numbers on lines $\mathrm{AB}$ and $\mathrm{AC}$ indicate melting proportions of OFB. Then it is found that the high pressure melting of OFB hardly makes increase of the $\mathrm{Rb} / \mathrm{K}$ ratio of the liquid fraction. The conditions for the high pressure fractional crystallization are the same as those of the high pressure partial melting. The high pressure fractional crystallization from the derivative liquid does not increase the $\mathrm{Rb} / \mathrm{K}$ ratio of the liquid to any extent. Therefore the range of various compositions of the high pressure derivatives from OFB can be accurately expressed by the line $\mathrm{AB}$ in Fig. 29, which corresponds to the range of the simplified $\mathrm{Rb}$ and $\mathrm{Sr}$ concentrations in the high pressure derivatives, as already shown in Figs. 21, 24 and 25. Lines $\mathrm{Px}^{1} \mathrm{Pl}^{1}$ and $\mathrm{Hb}^{1} \mathrm{Pl}^{1}$ in Fig. 29 are the variation trend of the convergent $\mathrm{K}$ and $\mathrm{Rb}$ concentrations attained through the zone melting of $\mathrm{a}$ 
material of the composition A in Fig. 29, when a pair of minerals of plagioclase and clinopyroxene, and that of plagioclase and hornblende in various proportions is assumed to be crystallized respectively. $\mathrm{E}^{\mathbf{1}}, \mathrm{F}^{\mathbf{1}}, \mathrm{D}^{\mathbf{1}}$ and $\mathrm{C}^{\mathbf{1}}$ in Fig. 29 represent the convergent composition of the liquid zone, when the mineral composition of the crystallizing material is assumed to be $a, b, b^{\prime}, c^{\prime}$ in Fig. 27 respectively. Then the variation range of the convergent composition of the liquid zone is expressed by the field $\mathrm{C}^{1} \mathrm{D}^{1} \mathrm{~F}^{\mathbf{1}} \mathrm{E}^{\mathbf{1}}$. When the composition is changed from $\mathrm{A}$ to $\mathrm{B}$ along the line $\mathrm{AB}$ in Fig. 29, then the variation range of the convergent composition is expressed by the trace of the field $\mathrm{C}^{1} \mathrm{D}^{1} \mathrm{~F}^{\mathbf{1}} \mathrm{E}^{\mathbf{1}}$ moved parallel to the line $A B$ from $C^{1} D^{1} F^{1} E^{1}$ to $C^{2} D^{2} F^{2} E^{2}$. This field of the variation range may slightly shift parallel to the line $\mathrm{AB}$ toward the upper right side as shown in Fig. 29, when the amount of quartz and other minerals of low partition coefficients in the crystallizing material is evaluated. The dotted field expresses the range of the

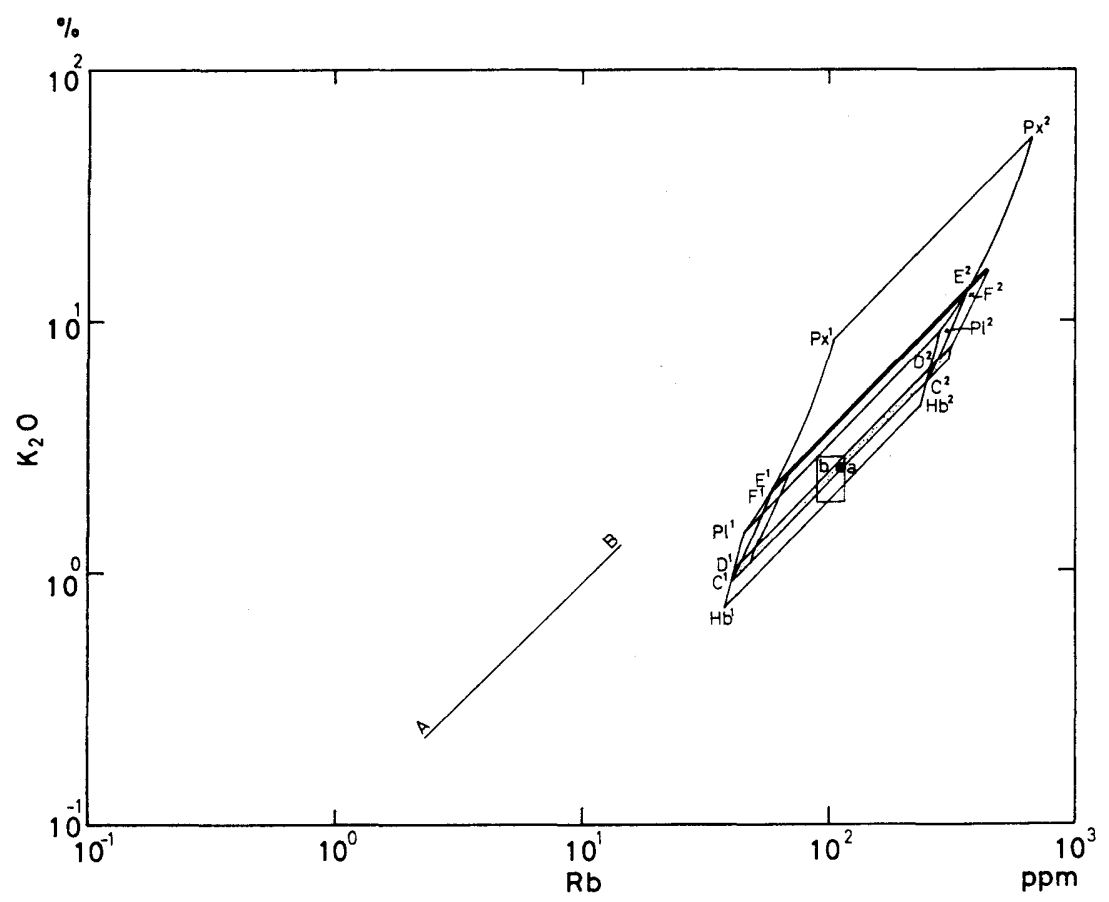

Fig. 29. Convergent concentrations of $\mathrm{Rb}$ and $\mathrm{K}$ attained by the liquid zone through the zone melting of the high pressure derivatives from OFB at low pressures. The line $A B$ shows the composition range of the high pressure derivatives. Letters $\mathrm{Hb}, \mathrm{C}, \mathrm{D}, \mathrm{Pl}, \mathrm{F}, \mathrm{E}$ and $\mathrm{Px}$ denote mineralogical constitutions of the crystallizing material, corresponding to E, I, H, C, F, G and D in Fig. 25 respectively. Numbers 1 and 2 written at the shoulder of each letter denote the composition of the melting material A and B respectively. The dotted field shows the range of the convergent concentrations of $\mathrm{Rb}$ and $\mathrm{K}$ in the liquid zone produced under water sufficient conditions. The point a represents the mean composition of the continental crust reported by Ahrens and TAYLOL (1961). The rectangle $b$ is the range of the mean compositions of the continental crust reported by Poldervaart (1955), Hurlex et al. (1962), TAYlor (1965) and Ronov and Yaroshevsky (1969). 
convergent composition attained under water sufficient conditions. The point $\mathbf{a}$ is the mean crustal composition reported by Ahrens and TAylor (1961). The rectangle represents a range of variation of mean crustal compositions reported by Poldervaart (1955), Hurley et al. (1962), Taylor (1965) and Ronov and YAROSHEVSKy (1969). The close coincidence of the dotted field with the mean crustal compositions supports the assumption that the magmatic process of zone melting under water sufficient conditions is operative for the formation of the continental crust.

It should, however, be minded that the $\mathrm{K}$ content in the liquid zone reaches about 7 percent for the highly fractionated case under the high pressure conditions. Then we cannot ignore the occurrence of a potassium rich phase like biotite and $\mathrm{K}$-feldspar in the crystallizing material. Since these potassium rich minerals have large partition coefficients of $\mathrm{Rb}$ and $\mathrm{K}$, the occurrence of a small amount of these minerals gives a profound effect on the variation trend of $\mathrm{Rb}$ and $\mathrm{K}$ concentrations in the liquid zone. Since the magnitude of the partition coefficient of $\mathrm{Rb}$ is similar to that of $\mathrm{K}$ for both minerals, the depression of both concentrations by the occurrence of biotite and $\mathrm{K}$-feldspar in the highly fractionated case proceeds nearly parallel to the line $A B$. The highly concentrated part of the field of the convergent composition of the liquid zone in Fig. 29 is depressed toward the lower left side. Therefore the convergent $\mathrm{Rb} / \mathrm{K}$ ratio of the liquid zone is not changed by the occurrence of these potassium-rich minerals.

In the previous discussion on the variation of $\mathrm{Rb}$ and $\mathrm{Sr}$ concentrations caused by the low pressure magmatic differentiations, we have assumed that the $\mathrm{Rb} / \mathrm{Sr}$ ratio of the high pressure derivatives from OFB is constant independently of $\mathrm{Sr}$ concentrations, and then the ratio is represented by the line AB in Figs. 21, 24 and 25. As it is found from Figs. 18 and 19, that the $\mathrm{Rb} / \mathrm{Sr}$ ratio of the high pressure derivatives, however, significantly increases simultaneously with the increase of the $\mathrm{Rb}$ or the $\mathrm{Sr}$ concentration. This simultaneous increase of the $\mathrm{Rb} / \mathrm{Sr}$ ratio may result in the significant increase of the convergent $\mathrm{Rb} / \mathrm{Sr}$ ratio with the increase of the $\mathrm{Sr}$ concentration in the liquid zone, exceeding the range already estimated (Fig. 25).

The result of the calculation of the $\mathrm{K}$ concentration in the liquid zone indicates the crystallization of a small amount of new potassium-rich phases in the highly concentrated case of $\mathrm{Rb}$ and also of Sr. The extent of depression of the convergent $\mathrm{Rb} / \mathrm{Sr}$ ratio of the liquid zone is shown respectively in Fig. 30 for two cases of the simultaneous crystallization of 5 percent $\mathrm{K}$-feldspar and 1 percent biotite with clinopyroxene, hornbende and plagioclase. The points a, b, c and d represent the model mineralogical constitutions of the crystallizing material and correspond to the points $a, b, c^{\prime}$ and $b^{\prime}$ in Fig. 27 respectively. Therefore the possible range of mineralogical constitution of the crystallizing material is 
expressed by the quardangle abcd. All of the calculations have been performed on the assumption that the $\mathrm{Rb} / \mathrm{Sr}$ ratio of the melting material is 0.0177 . The solid lines represent the variation of the convergent $\mathrm{Rb} / \mathrm{Sr}$ ratio dependent on the abundances of major three minerals of plagioclase, clinopyroxene and hornblende. The dotted and broken lines represent the variation of the convergent $\mathrm{Rb} / \mathrm{Sr}$ ratio for two cases of crystallization of additional 1 percent biotite and 5 percent $\mathrm{K}$ feldspar respectively. Then it is obvious from Fig. 30 that the introduction of a small amount of these potassium-rich minerals markedly depresses the convergent $\mathrm{Rb} / \mathrm{Sr}$ ratio of the liquid zone.

Since these potassium-rich minerals occurs in the highly concentrated case of $\mathrm{K}$, nearly proportional increase of potassium-rich minerals to the convergent $\mathrm{Sr}$ concentration in the liquid zone can compensate the difference between the simplified and the calculated compositions of the high pressure derivatives from OFB. The difference becomes distinct with the increase of the $\mathrm{Sr}$ concentration in the derivatives. This difference has already been mentioned as the residual $\mathrm{Rb} / \mathrm{Sr}$ ratio of the derivatives in the foregoing section. Like this, the potassium-rich minerals play an important role during the magmatic differentiation of zone melting. When the $\mathrm{Rb}$ content in the liquid zone is increased slightly, resulting from the variation of the composition of the derivatives ascending from the seismic zone, the $\mathrm{K}$ content in the liquid zone may also be increased simultaneously. Then the abundance of the potassium-rich minerals may be so much increased

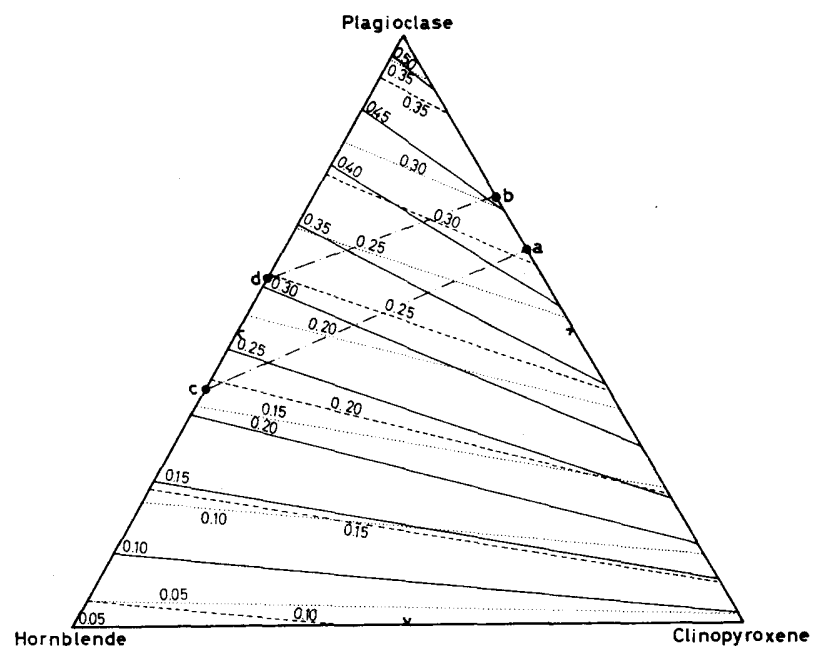

Fig. 30. The effect of crystallization of a small amount of potassium-rich minerals on the convergent $\mathrm{Rb} / \mathrm{Sr}$ ratio of the liquid zone. Solid lines are the same as those in Fig. 27. Broken and dotted lines show the convergent $\mathrm{Rb} / \mathrm{Sr}$ ratio resulted from the simultaneous crystallization of $5 \%$ potassium feldspar and of $1 \%$ biotite with plagioclase, hornblende and clinopyroxene respectively. Points $\mathrm{a}, \mathrm{b}, \mathrm{c}$ and $\mathrm{d}$ correspond to $\mathrm{a}, \mathrm{b}, \mathrm{c}^{\prime}$ and $\mathrm{b}^{\prime}$ in Fig. 27 respectively. 
that the $\mathrm{Rb} / \mathrm{Sr}$ ratio of the liquid zone begins to decrease. As a negative feed back system like this is organized, the $\mathrm{Rb} / \mathrm{Sr}$ ratio may remain unchanged.

\section{The Formation of a Granite from the Primary Crust}

Now it has been so explicitly manifested through the foregoing discussions that a material of a high $\mathrm{Rb} / \mathrm{Sr}$ ratio and a high $\mathrm{Rb}$ concentration comparable to the mean of granites could not be produced from $\mathrm{OFB}$ and either from the upper mantle material. Therefore, an additional magmatic differentiation or an existence of a high $\mathrm{Rb} / \mathrm{Sr}$ ratio material in the upper mantle should be taken into consideration. The possibility of the existence of the high $\mathrm{Rb} / \mathrm{Sr}$ ratio material in the mantle is so small that there is only one way left through which the granite is produced from a material of the mean crustal composition, because the existense of this material in the mantle could not explain the low initial $\mathrm{Sr}(87 / 86)$ ratios of granites. The formation of the primary crust has already been proved to be possible through the magmatic processes from OFB. It has already been shown

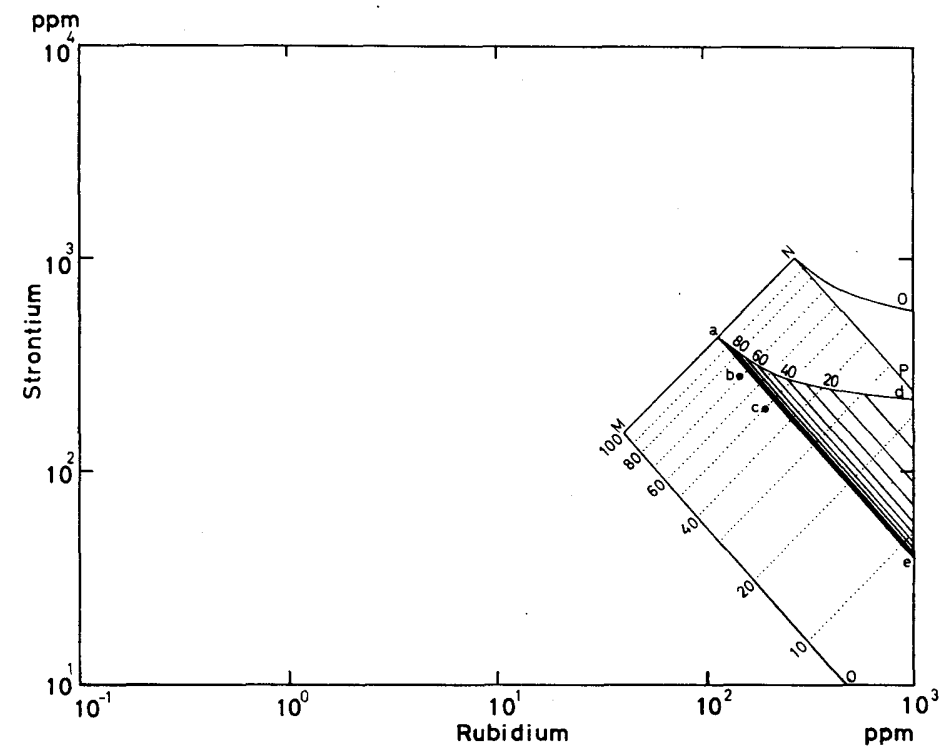

Fig. 31. The range of $\mathrm{Rb}$ and $\mathrm{Sr}$ concentrations in a liquid produced by the partial melting followed by fractional crystallization at low pressures from the primary crust. The line MN shows the range of composition of the primary crust. The line ad is a trend traced by the liquid with the progress of the partial melting of the primary crust of the composition a. A set of lines parallel to the line ae shows the fractionation trend of the liquid originated from the various melting proportions of the primary crust. Dotted lines show compositions of the residual liquid after every 10 percent fractional crystallization from the total melt of the primary crust. Lines QM and NO limit the range of the composition of the liquid produced through the partial melting followed by the fractional crystallization from the primary crust. Points $\mathbf{a}, \mathbf{b}$ and $\mathbf{c}$ are the same as those in Fig. 21. 
that the primary crust has the specific $\mathrm{Rb} / \mathrm{Sr}$ ratio. This ratio is comparable to the mean abundace ratio of both elements in the continental crust and independent of its position in the island arc. Therefore there is no objection to regard the composition of the primary crust as being equivalent to the convergent composition of the liquid zone, which is produced from the high pressure derivatives through the magmatic process analogous to the zone refining processing of the semi-conductive material. This composition of the primary crust is shown as the line $\mathrm{MN}$ in Fig. 31. The liquid traces the line ad in Fig. 31 toward the point a with the advance of the equilibrium partial melting of the primary crust of a composition a in Fig. 31, the mean composition of the continental crust. Numbers on the line ad are proportions of the liquid to the source. A suite of straight lines parallel to the line ae is the fractionation trend of the liquids of various melting proportions. Therefore we get a field QMNO as the possible range of composition of the derivative liquid from the primary crust, when the composition of the primary crust is changed from $\mathrm{M}$ to $\mathrm{N}$ along the line $\mathrm{MN}$. The dotted lines represent a proportion of the residual liquid which is produced by the total melting from the primary crust followed by the fractional crystallization. The mean compositions of granites are in the middle of the field QMNO. Then it is manifested that the granite could be produced from the primary crust by the partial melting. In connection with this result, it is noted that the two mean compositions of the granites and the mean composition of the continental crust are arranged in a line nearly parallel to the fractionation trend ae in Fig. 31.

\section{Concluding Remarks}

\section{(1) Summary}

The consecutive investigations on the variation of $\mathrm{Rb}$ and $\mathrm{Sr}$ concentrations in a series of the derivatives from OFB have indicated the possibility of the existence of the upward flow of the upper mantle material driven by the gravitational rise of an enormous amount of the derivatives from OFB under the island arc, and have manifested a possible chain of processes of the magmatic differentiation from the partial melting of OFB at the seismic zone in the depth of the mantle to the formation of the primary crust and of the granite near the base of the crust at the island arc. It is obvious that none of the high pressure magmatic differentiations can produce the continental crust and also the granite from OFB or from the upper mantle material.

The low pressure fractional crystallization of the high pressure derivative melt cannot sufficiently explain the $\mathrm{Rb}$ and the $\mathrm{Sr}$ contents in the continental crust and also in the granites. Therefore the low pressure fractionation could not be regarded as principal in the magmatic processes for the formarion of the 
continental crust. When the formation of the continental crust from the upper mantle material was supposed to depend largely on this type of fractionation, we should seek for an effective geochemical mechanism which increases $\mathrm{Rb}$ content without any increase or decrease of Sr content.

The most probable way of differentiation for the formation of the continental crust is the magmatic process analogous to the zone refining processing of the semi-conductive material. The equilibrium incipient melting of the high pressure derivatives under low pressure dry conditions, however, is not ignored, because we can explain the mean abundances of $\mathrm{Rb}$ and $\mathrm{Sr}$ in the continental crust by means of partial melting. These two alternative models of the formation of the continental crust give us an idea that the growth rate of the continental crust is proportional to the sinking rate of the oceanic plate at the island arc.

The zone melting of the high pressure derivatives under low pressure wet conditions can sufficiently account for the now available abundances of $\mathrm{Rb}, \mathrm{Sr}$ and $\mathrm{K}$ in the continental crust and also for the major chemical composition of the lower crust which has been infered from the variation of the $\mathrm{Rb} / \mathrm{Sr}$ ratio of various volcanic rocks. This major chemical composition is consistent with the now available estimates of the overall chemical composition of the continental crust.

The magmatic differentiation scheme of zone melting brings about the formation of the primary crust, from which a granitic magma, in turn, can be derived through the partial melting, along the extension of the island arc at the same period of the plate tectonics. This primary crust has the specific and constant $\mathrm{Rb} / \mathrm{Sr}$ ratio independently of its position in the island arc and also of an relatively young age of its formation. This $\mathrm{Rb} / \mathrm{Sr}$ ratio does not vary among the island arcs and corresponding orogenic belts.

The partial melting of the newly formed continental crust, viz., the primary crust, gives rise to a granitic magma. Then the lower crust, now the residuum of the primary crust, becomes stable and more basic with high $\mathrm{Sr}$ contents and low $\mathrm{Rb} / \mathrm{Sr}$ ratios comparable to those of andesites and basalts. The stable lower crust has no ability to give rise to a granitic magma any more. This stable lower crust may not contaminate a magma of acid-intermediate composition but may contaminate a magma of basaltic composition.

\section{(2) Additional supports}

CANN (1970) insisted that the water sufficient magma like the partial melting products from the sedimentary rocks found at the middle of the orogenic belt cannot move upward far from the original position, but the magma produced at the lower crust can intrude into the upper part of the crust, because the magma produced under water sufficient conditions reaches the solidus temperature immediately with the adiabatic rise from the original position. BRown and Fyfe (1970), and LAmbert and Wyllei (1970) have reported that a granitic magma 
could be produced when the physical conditions reach to those of the granulite facies. These conditions are attained at the lower part of the crust. BRown and Fyfe found that the mixture of hydrated mafic minerals, plagioclase and quartz in various proportions can give rise to a material of chemical composition comparable to granites through the low pressure partial melting.

A material of basaltic composition, if present at the lower crust, should exist as eclogite, but the density of eclogite is too high for measured seismic properties of the lower crust. So, Ringwood and Green (1966) proposed that we should abundon the notion of a basic lower crust and instead consider an assemblage of acid-intermediate rocks in eclogite facies. GREEN (1971) has experimentally proved that an anothositic or a dioritic model of the lower crust, which has already differentiated, accounts for the seismic properties of the lower crust.

These circumstances match well with the conclusion on the formation of the primary crust. Much of geochemical and geophysical aspects of the continental crust are well explained, if we assume that the continental crust has been formed through the zone melting. Accordingly we should abandon the preconception that the continental crust has grown through volcanism, sedimentation and succeeding metamorphism through orogenic movements. The continental crust must have grown continuously or episodically downward by the addition to its base of a new crustal material derived from OFB.

\section{(3) The relation between the formation of the primary crust and the apparent growth of the initial $\operatorname{Sr}(87 / 86)$ ratios}

The model of the formation of the primary crust with the specific $\mathrm{Rb} / \mathrm{Sr}$ ratio and that of the granites suggest the presence of the systematic time-dependent variation of the initial $\mathrm{Sr}(87 / 86)$ ratios of granites. Therefore a $\mathrm{Rb} / \mathrm{Sr}$ ratio determined from the rate of the growth should be equivalent to the specific $\mathrm{Rb} / \mathrm{Sr}$ ratio of the primary crust. The growth line found among the initial $\mathrm{Sr}(87 / 86)$ ratios of some granites from Southwest Japan sufficiently fulfills this condition.

The $\operatorname{Sr}(87 / 86)$ ratio of the primary crust should be equivalent to the mean of OFB. The $\mathrm{Sr}(87 / 86)$ ratios in the volcanic rocks, however, are biased toward the higher side by 0.0006 . Accordingly it is reasonable to assume that the $\operatorname{Sr}(87 / 86)$ ratio of the primary crust is somewhat higher than the mean of OFB and is close to 0.7033 . Therefore the formation of the source primary crust of a suite of granites lying on the growth line is estimated at about 400 m.y. ago. And the source of the Itoshima and the Sawara granitic rocks is estimated to have been formed about 230 m.y. ago.

\section{(4) The role of the crystallization of garnet}

We have ignored the occurrence of garnet in the material crystallizing from the liquid. GreEN (1972) has, however, demonstrated that the garnet is a stable 
liquidus phase for the andesitic composition under wet conditions at pressures over than $10 \mathrm{~kb}$.

Both partition coefficients of $\mathrm{Rb}$ and $\mathrm{Sr}$ for garnet are negligibly small. Therefore the crystallization of garnet has a negligible effect on the convergent $\mathrm{Rb} / \mathrm{Sr}$ ratio of the liquid zone, but gives profound effect to the convergent concentrations of $\mathrm{Rb}$ and $\mathrm{Sr}$. The trend of variation of both convergent concentrations caused by the crystallization of garnet is analogous to that resulted from the crystallization of quartz and magnetite. The increase of an amount of garnet results in the simultaneous increase of both concentrations, and also of potassium concentration. The depth of the operation of the zone melting may be increased with the thickening of the continental crust. Then both concentrations may be increased with the thickening of the continental crust. Accordingly granites at the early stage of the growth of the continental crust may have comparatively low contents of $\mathrm{Rb}$ and $\mathrm{Sr}$. The contents of $\mathrm{Rb}$ and $\mathrm{Sr}$ in the granite are increased with the growth of the continental crust. This trend of variation may well appear in the Sr content, because the Sr content is not incrased by the low pressure magmatic differentiation.

This variation trend resulted from the crystallization of garnet is the same for either case of formation of the continental crust through the zone melting or through the incipient partial melting. Then it follows that the distinction of two types among granites from Southwest Japan has an important meaning for the growth of the continental crust in Southwest Japan.

The thickening of the continental crust, that is, the increase of the depth of operation of the zone melting, results in the extinction of plagioclase crystallizing in the liquid zone as shown by the experiments of GREen (1972). Then the crustal material with the specific $\mathrm{Rb} / \mathrm{Sr}$ ratio cannot be produced through any kind of magmatic differentiation. Therefore the extinction of plagioclase limits the muximum thickness of the continental crust. GreEN (1972) demonstrated that the extinction of plagioclase depends largely on the water content in the liquid melt. According to his experiments on the andesite +5 percent by weight of water, plagioclase disappears at about $900 \mathrm{C}, 12 \mathrm{~kb}$. This pressure corresponds to about $45 \mathrm{~km}$ in thickness of the continental crust. The relatively uniform thickness of the continental crust may reflect these circumstances.

\section{(5) The incorporation of basalt into the formation of the primary crust}

I have regarded the high pressure derivatives from OFB as the intermediate for the formation of the primary crust. This intermediate has been regarded to be basaltic andesite or andesite in composition. But it has been already noticed that the distinction is hardly drawn between basalts and andesites with low 
$\mathrm{Sr}(87 / 86)$ ratios in terms of $\mathrm{Rb}$ and $\mathrm{Sr}$ contents. Therefore there is no objection to assume that some amount of basaltic material takes part in the formation of the primary crust. Some variation of the major chemical composition in the primary crust may result from the incorporation of the basaltic material into the magmatic process of zone melting, although the conditions are almost the same for the convergent concentrations of $\mathrm{Rb}$ and $\mathrm{Sr}$. This variation of the primary crust may result in the difference in major chemical composition of granites.

Finally, I should like to point out that the flow in the upper mantle may have taken part in the origin of the Japan Sea and in giving difference in geological structures between Southwest and Northeast Japan. The residuum of low pressure magmatic differentiations would be discovered along and off the Japan Sea coast of the Japanese Islands. The residuum may be strongly sheared and foliated because of the differential movement in the upper mantle.

\section{Acknowledgements}

I wish to thank Professors Tatsuro Matsumoto and Sadakatsu Taneda, Associate Professors Masaru Yamaguchi and Hitoshi Momor, and Dr. Kiyoshi Ishibashi of the Kyushu University for critical reading of the manuscript, helpful comments and discussions. I owe much to Miss Reiko Hamamoto for her help in operation of the mass spectrometers during the course of this study. This study has been finantially supported by a Grant-in-Aid for the Scientific Research from the Ministry of Education and by the Ito Science Foundation.

\section{References Cited}

Ahrens, L. A. and TaYlor, S. R. (1961): Spectorochemical Ananysis, 1-454, Addison-Wesley, Massachusets.

AkI, K. (1966): Earthquake generating stress in Japan for the years 1961 to 1963 obtained by smoothing the first motion radiation patterns, Bull. Earthq. Res. Inst., 44, 447-471.

Berin, R. and Henderson, C. B. M. (1969): The distribution of $\mathrm{Sr}$ and $\mathrm{Ba}$ between the alkali feldspar, plagioclase and groundmass of porphyritic trachytes and phonolites, Geochim. Cosmochim. Acta, 33, 247-255.

Brown, G. C. and FrFk, W. S. (1970): The production of granitic melts during ultrametamorphism, Contr. Mineral. Petrol., 28, 310-318.

CANN, J. R. (1970): Upward movement of granitic magma, Geol. Mag., 107, 335-340.

(1970b): $\mathrm{Rb}, \mathrm{Sr}, \mathrm{Y}, \mathrm{Zr}$ and $\mathrm{Nb}$ in some ocean floor basaltic rocks, Earth Planet. Sci. Letters, 10, 7-11.

(1971): Major element variations in ocean-floor basalts, Phil. Trans. Roy. Soc. Lond., A, 268, 495-505.

Drckinson, W. R. (1970): Relation of andesites, granites and derivative sandstones to arctrench tectonics, Rev. Geophys. Space Phys., 8, 813-860. and Hatherton, T. (1967): Andesitic volcanism and seismicity around the Pacific. Science, 157, 801. 
Donnelly, T. W., Rogers, J. J. W., Pushrar, P., and Armstrong, R. L. (1971): Geochemical evolution of the eastern West Indies: An investigation of thorium, uranium and lead, and strontium isotope ratios, Geol. Soc. Amer. Mem., 130, 181-224.

Ewart, A. and Stipp, J. J. (1968): Petrogenesis of the volcanic rocks of the Central North Island, New Zealand, as indicated by a study $\mathrm{Sr}^{87} / \mathrm{Sr}^{80}$ ratios, and $\mathrm{Sr}, \mathrm{Rb}$, U and Th abundances, Geochim Cosmochim. Acta, 32, 699-736.

Faure, G. and Powell, J. L. (1972): Strontium isotope geology, 1-188, Springer-Verlag, New York.

Ferrara, G., Clarke, W. B., Murthy, V. R. and Bass, M. N. (1969) : K-Ar ages of Juan Fernandez Islands and southeast Pacific drege hauls (Abstract), Amer. Geophys. Union Trans., 50, 329, 4969.

GAST, P. W. (1960): Limitations on the composition of the upper mantle, Jour. Geophys. Res., 65, 1287-1297.

(1967): Isotope geochemistry of volcanic rocks, In: Hess, H. H. and Poldervaart, A. (eds.) Basalt-the Poldervaart treaties on rocks of basaltic composition, 325-358, Interscience, New York.

(1968): Trace element fractionation and the origin of tholeiitic and alkaline magma types, Geochim. Cosmochim. Acta. 32, 1057-1086.

GiLl, J. B. (1970): Geochemistry of Viti Levu, Fiji and its evolution as an island arc, Contr. Mineral. Petrol., 27, 179-203.

Goodman, R. J. (1972): The distribution of $\mathrm{Ga}$ and $\mathrm{Rb}$ in coexisting groundmass and phenocryst phases of some basic volcanic rocks, Geochim. Cosmochim. Acta, 36, 307317.

Green, D. H. and Ringwood, A. E. (1967): The genesis of basaltic magma, Contri. Mineral. Petrol., 15, 103-190.

GreEN, T. H. (1970): High pressure experimental studies on the mineralogical constitution of the lower crust, In: A. E. Ringwoon and GreEN, D. H., (eds)., Earth Planet. Inter. iors, 3, 411-450, North-Holland, Amsterdam.

(1972): Crystallization of calc-alkaline andesite under controlled high-pressure hydrous conditions, Contr. Mineral. Petrol., 34, 150-166.

- and Ringwood, A. E. (1968): Genesis of the calc-alkaline igneous rock suite, Contr, mineral. petrol., 18, 105-162.

Griffin, W. L. and Murthy, V. R. (1969): Distribution of K, Rb, $\mathrm{Sr}$ and $\mathrm{Ba}$ in some minerals relevant to basalt genesis, Geochim. Cosmochim. Acta, 33, 1389-1414.

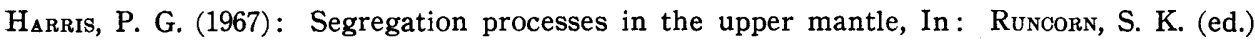
Mantles of the Earth and Terrestrial Planets, 305, Wiley, London.

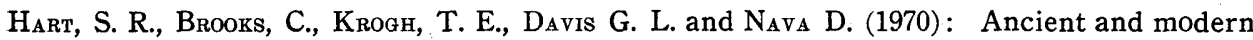
volcanic rocks: a trace element model, Earth Planet. Sci. Letters, 10, 17-28.

- , Glasslex W. E. and Karia, D. E. (1972): Basalts and sea floor spreading behind the Mariana island arc, Earth Planet. Sci. Letters, 15, 12-18.

Hatherton, T. and Dickinson W. R. (1969): The relationship between andesitic volcanism and seismicity in Indonesia, the Lesser Antilles, and other island arcs, Jour. Geophys. Res., 74, 5301-5310.

HAYASE, I and Ishrzaka, K. (1967): Rb-Sr dating on the rocks in Japan (1), Southwest Japan, Jour. Japan. Assoc. Mineral. Petrol. Econ. Geol., 58, 201-212. (In Japanese with English abstract).

and NoHda, S. (1969): Geochronology on the "Oldest rock" of Japan, Geochem. Jour., 3, 45-52.

HeDGe, C. E. (1966): Variations in radiogenic strontium found in volcanic rocks, Jour. Geophys. Res., 71, 6119-6126. and KNighт, R. J. (1969): Lead and strontium isotopes in volcanic rocks from northern Honshu, Japan, Geochem. Jour., 3, 15-24. , Hildreth, R. A. and Henderson, W. T. (1970): Strontium isotopes in some Cenozoic lavas from Oregon and Washington, Earth Planet. Sci. Letters, 8, 434-438. 
and Peterman Z. E. (1970): The strontium isotopic composition of basalts from the Gordo and Juan de Fuca, Northeastern Pacific Ocean, Contr. Mineral. Petrol., 27, 114-120.

and LEWIS, J. F. (1971): Isotopic composition of strontium in three basalt-andesite centers along the Lesser Antilles Arc, Contr. Mineral. Petrol., 32, 39-47.

HiquChi, H and NagaSaWA, H. (1969): Partition of trace elements between rock forming minerals and the host volcanic rocks, Earth Planet. Sci. Letters, 7, 281-287.

Hurley, P. M., Hughes, H., Faure, G., Fairbairn, H. W. and Pinson, W. H. (1962): Radiogenic strontium-87 model of continental formation, Jour. Geophys. Res., 67, 5315-5334. and RaND, J. R. (1969): Pre-drift nuclei, Science, 164, 1229-1242.

ICHJKAWA, K., Ishi, K., NAGASAWA, C., SUYARI, K. and YamaShita, N. (1956): The Kurosegawa structural belt, Jour. Geol. Soc. Japan, 62, 82-103. (In Japanese with English abstract).

Isaks, B., Oliver, J. and SYres, L. R. (1968): Seismology and the new grobal tectonics, Jour. Geophys. Res., 73, 5855-5899.

IshIzaKa, K. (1971): A Rb-Sr isotopic study of the Ibaragi granitic complex, Osaka, Japan, Jour. Geol. Soc. Japan, 77, 731-740.

(1972): $\mathrm{Rb}-\mathrm{Sr}$ dating on the igneous and metamorphic rocks of the Kurosegawa Tectonic Zone, Jour. Geol. Soc. Japan, 78, 569-575. (In Japanese with English abstract).

Isomr, $H$ (1968): Tectonic map of Japan, $1: 2,000,000$ map series 12, Geol. Surv. Japan.

K KNAMORI, H. (1970): Mantle beneath the Japanese Arc, In: Ringwood, A. E. and Green, D. H. (eds.), Phys. Earth Planet. Interiors, 3, 475-483, North-Holland, Amsterdam.

Karakida, Y., Tomtta, T., Gotteried, D., Sterm, T. W. and Rose, H. J. Jr. (1965): Lead-alpha ages of some granitic rocks from North Kyushu and Central Japan, Mem. Fac. Sci, Kyushu Univ., [D], 16, 249-263.

KAWANo, Y. and UEDA, Y. (1966): K-Ar dating on the igneous rocks in Southwest Japan, Jour. Japan. Assoc. Mineral. Petrol. Econ. Geol., 56, 191-211, (In Japanese with English abstract).

$\mathrm{K}_{\mathrm{AY}}, \mathrm{R}$., HubBard, N. J. and $\mathrm{G}_{\triangle S \mathrm{ST}}, \mathrm{P} . \mathrm{W}$. (1970): Chemical characteristics and origin of oceanic ridge volcanic rocks, Jour. Geophys. Res., 75, 1585-1613.

Kuno, H. (1959): Origin of Cenozoic Petrographic province of Japan and surrounding areas, Bull. Volcanol., Ser. II, 37-76.

(1966): Lateral variation of basalt magma type across continental margin and island arcs, Bull. Volcanol., 29, 195-222.

(1968): Origin of andesite and its bearing on the island arc structure, Bull. Volcanol., 32, (1), 141-176.

Lambert, I. B. and Wyluie, (1970): Melting in the deep crust and upper mantle and the nature of the low velocity layer, In: Ringwood, A. E. and GREEN, D. H. (eds)., Phys. Earth Planet. Interiors, 3, 316-322, North-Holland, Amsterdam.

Le Prchon, X. (1968): Sea-foor spreading and continental drift, Jour. Geophys. Res., 73, 3661-3697. , F Fancheteau, J. and Bonnis, J. (1973): Plate tectonics, Developments in Geotectonics, 6, 1-311, Elsevier, Ameterdam.

Matsumoтo, T. (1968): Geochronology and historical geology in Japan, Mass Spectro., 17, 434-444.

and $\mathrm{K}_{\triangle \mathrm{NMERA}}, \mathrm{K} .(1949)$ : Contribution to the tectonic history in the Outer Zone of Southwest Japan, Mem. Fac., Kyushu Univ., [D], 3, 77-90. and (1964): Geological map of the Hinagu quadrangle (scale, $1: 50,000$ ) and explanatory text, Geol. Surv. Japan.

Matsushita, H. (1971): A study on the formation of the depositional basins of the coalfields in Kyushu, Sci. Rept., Kyushu Univ., Geol., 11, 1-16 (In Japanese with English abstract).

Minato, M, Gorai, M. and Funahashi N. (eds.) (1965): The geologic development of the Japanese Islands, 1-442, Tsukiji, Tokyo. 
Mirashiro, A. (1972): Metamorphism and related magmatism in plate tectonics, Amer. Jour. Sci., 272, 629-656.

Nagasawa, H. and Sohnetzler, C. C. (1971): Partitioning of rare earth, alkali and alkaline earth elements between phenocrysts and acid igneous magma, Geochim. Cosmochim. Acta, 35, 953-968.

NoHda, S. (1972): A Rb-Sr isotopic study of the Yatsushiro granite and gneiss, Kyushu, Japan, with refernce to the Japanese Islands, $\mathrm{Ph}$. D. Thesis, Kyoto Univ.

Nozawa, T. (1963): Radiometric ages of granitic rocks in Outer Zone of Southwest Japan and its extension; 1968 summary and north-shift hypothesis of igneous activity, Jour. Geol. Soc. Japan, 74, 485-489, (In Japanese with English abstract).

(1970): Isotopic ages of late Cretaceous acid rocks in Japanese Islands; Summary and notes in 1970, Jour. geol. Soc. Japan, 76, 493-518.

Onuma, N., Hiquohr, H., Wakita, H. and Nagasawa, H. (1968): Trace elements partition between two pyroxenes and the host lavas, Earth Planet. Sci. Letters, 5, 47-51.

Peterman, Z. E., Carmichael, I. S. E. and Smith, A. L. (1970): $\mathrm{Sr}^{87} / \mathrm{Sr}^{86}$ ratios of Quaternary lavas of the Cascade Range, Northern California, Geol. Soc. Amer. Bull., 81, 311-318.

Philpotts, J. A. and Schnetzler, C. C. (1970): Phenocryst-matrix partition coefficients for $\mathrm{K}, \mathrm{Rb}, \mathrm{Sr}$ and $\mathrm{Ba}$ with application to anothosite and basalt genesis, Geochim. Cosmochim, Acta, 34, 307-322.

Poldervaart, A. (1955): Chemistry of the Earth's crust, In: Poldervaart, A. (ed.), Crust of the Earth, Geol. Soc. Amer., Special Paper, 62.

Pushrar, P. (1968): Strontium isotope ratios in volcanic rocks of the three island arcs, Jour. Geophys. Res., 73, 2701-2714.

- Steuber, A. M., Tomblin, J. F. and Jurian, G. M. (1973): Strontium isotope ratios in volcanic rocks from St. Vincent and St. Lucia, Lesser Antilles, Jour. Geophys. Res., 78, 1279-1287.

Ringwood, A. E. and Green, D. H. (1966): Petrological nature of the stable continental crust, In: J. S. Steinhart and T. J. Sмith, eds., The Earth beneath the Continents, Geophys. Monograph, 10, 611, Amer. Geophys. Union.

Ronov, A. B. and YArosherskr, A. A. (1969): Chemical composition of the Earth's Crust, In: HaRT, P. J. (ed.), The Earth's Crust and Upper Mantle, Geophys. Monograph, 13, Amer. Geophys. Union.

Shannon, R. D. and Prewits, C. T. (1969): Effective ionic radii in oxides and fluorides, Acta Cryst. B52, 925-946.

Shibata, K. and Nozawa, T. (1966): K-Ar ages of granites from Amami-oshima, Ryukyu Islands, Japan. Bull. Geol. Surv. Japan, 17, (7), 430-435. , , and WANLESS, R. K. (1970): Rb-Sr geochronology of the Hida metamorphic belt, Japan, Can, Jour. Earth Sci., 7, 1383-1401.

Shimazu, Y. (1961): Physical theory of generation, upward transfer, differentiation, solidification and explosion of magma, Jour, Earth Sci. Nagoya Univ., 9, 185-223.

Subbarao, K. V. (1972): The strontium isotope composition of basalts from the East Pacific and Chile rises and abyssal hills in the eastern Pacific Ocean, Contr. Mineral. Petrol., 37, 111-120.

Sugimura, A. (1967): Chemistry of volcanic rocks and seismicity of the earth's mantle in the island arcs, Bull. Volcanol., 30, 319-334. -, Matsuda, T., Chinzei, K. and Nakamura, K. (1963): Quantitative distribution of of late Cenozoic volcanic materials in Japan, Bull. Volcanol., 26, 125-140.

Takeuchi, H., Hamano, Y. and Hasegawa, Y. (1968): Rayleigh- and Love-wave discrepancy and existence of magma pockets in the upper mantle. Jour. Geophys., Res., 73, 33493350.

T Atsumoto, M., Hedge, C. E. and Engel, A. E. J. (1965): Potassium, rubidium, strontium, thorium, uranium and the ratio of strontium- 87 to strontium-86 in oceanic tholeiitic basalt, Science, 150, 886-888. 
TAYLOR, S. R. (1965): The application of trace element data to problems in petrology, In: Ahrens L. A., Runcorn, F. and Urey, C. (eds)., Physics and chemistry of the Earth, 6, 133-214, Pergamon, London.

(1968): Geochemistry of andesites, In : Ahrens, L. H. (ed.), Origin and distribution of the elements, Pergamon, London.

Turemian, K. K. and Kulp, J. P. (1965): The geochemistry of strontium, Geochem. Cosmochim. Acta, 10, 245-296.

Ueda, S. and Horat, K. (1964): Terrestrial heat flow in Japan, Jour. Geophys. Res., 69, 2121-2141. and Sugrmura, A. (1970): Island arcs, 1-156, Iwanami, Tokyo (In Japanese).

Vaquier, V., Ueda, S., Yasur, M., Sclater, J., Corry, C. and Watanabe, T. (1966): Studies of the thermal state of the earth, heat-flow measurements in the northern Pacific, Bull. Earthq. Res. Inst., 44, 1519-1535.

WrLLIE, P. J. (1971): The dynamic earth, 1-416, Jhon Wiley, New York.

YAMAGUCHI, M., YANAGI, T. and HAMAMOTO, R. (1968): Some technical aspects of the rubidiumstrontium geochronology, Mem. Fac. Sci., Kyushu Univ., [D], 19, 437-450.

YANAGI, T. (1971): Rb-Sr ages of the granodiorite in Hakimachi, Fukuoka, Japan, Sci. Rept., Kyushu Univ., Geol., 11, 45-48, (In Japanese with English abstract). and YAMAGUCHI, M. (1970): Ages of some Precambrian metamorphic rocks in North China, Mem. Fac. Sci., Kyushu Univ., [D], 20, 177-189.

, Y YMAGUCHI, M. and NozAWA, T. (1971): Rb-Sr whole rock ages of the granites of Minami-osumi and Amami-oshima, Southwest Japan, Mem. Fac. Sci., Kyushu Univ., [D], 21, 163-175. 